College of William \& Mary Law School William \& Mary Law School Scholarship Repository

2004

\title{
Australia and the United States: Two Common Criminal Justice Systems Uncommonly at Odds
}

Paul Marcus

William \& Mary Law School, pxmarc@wm.edu

Vicki Waye

\section{Repository Citation}

Marcus, Paul and Waye, Vicki, "Australia and the United States: Two Common Criminal Justice Systems Uncommonly at Odds" (2004). Faculty Publications. 224.

https://scholarship.law.wm.edu/facpubs/224

Copyright c 2004 by the authors. This article is brought to you by the William \& Mary Law School Scholarship Repository. https://scholarship.law.wm.edu/facpubs 


\title{
Australia and the United States: Two Common Criminal Justice Systems Uncommonly at Odds
}

\author{
Paul Marcus \\ Vicki Waye ${ }^{\dagger}$
}

\begin{abstract}
At first glance the criminal justice systems of Australia and the United States look strikingly similar. With common law roots from England, they both emphasize the adversary system, the role of the advocate, the presumption of innocence, and an appeals process. Upon closer reflection, however, they appear starkly different. From both Australian and U.S. perspectives, the authors explore those differences, examining important features such as the exclusion of evidence, rules regarding interrogation, the entrapment defense, and the open nature of trials. The Article concludes with an analysis of the reasons for those differences, reasons that heavily relate back to the founding of the two nations and the drafting of distinctly dissimilar constitutions.
\end{abstract}

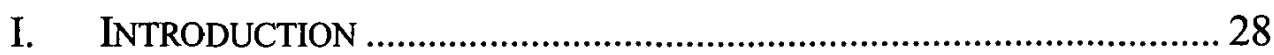

II. NATURE OF REGULATION OF CRIMINAL PROCEDURE .......................... 29

A. In Australia ............................................................................ 29

B. In the United States ............................................................. 32

III. WE ARE SO VERY MUCH ALIKE......................................................... 33

A. The Golden and Silver Threads: Presumption of

Innocence and Proof Beyond a Reasonable Doubt .................. 34

B. Voluntariness, the Taking of Confessions ..................................35

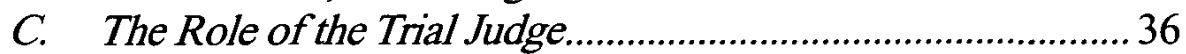

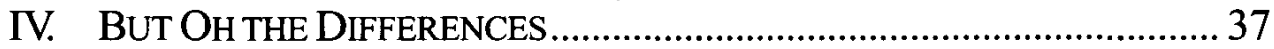

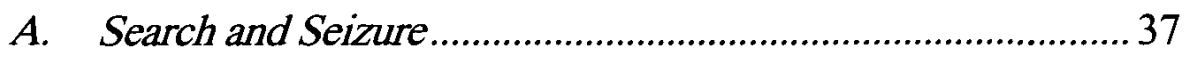

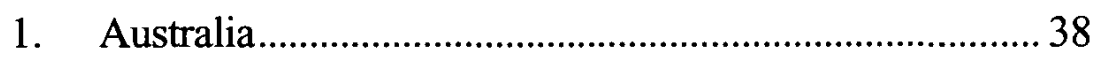

2. United States.................................................................. 43

a. The Drug War .........................................................46

b. Organized Crime ………………………………........47

c. Drunk Driving .........................................................47

d. Searches of Public School Children........................48

e. Plain View Doctrine....................................................49

f. Consent .....................................................................

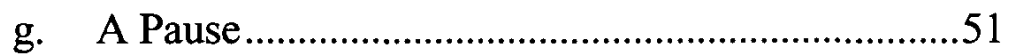

B. Exclusion of Evidence .......................................................... 55

* Haynes Professor of Law, College of William and Mary, U.S.A.

$\dagger \quad$ Senior Lecturer, University of Adelaide, Australia. 


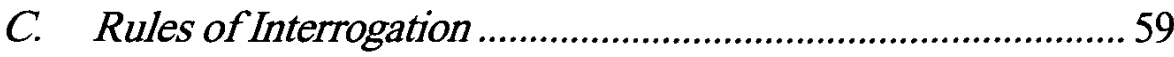

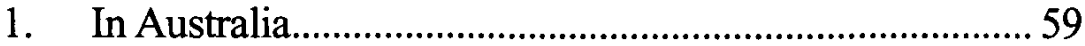

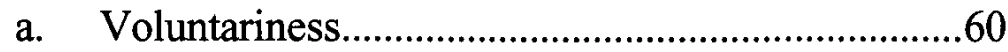

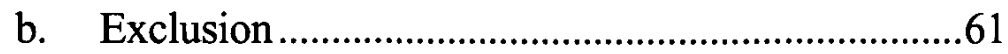

2. In the United States .........................................................64

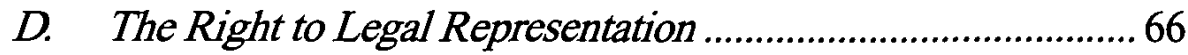

E. The Appeals Process ............................................................... 70

F. The Entrapment Defense ......................................................

1. The United States ............................................................. 71

2. Australia........................................................................ 73

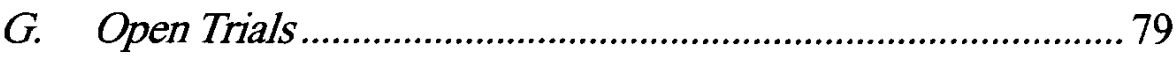

1. Prior Restraints ............................................................... 79

a. The United States.....................................................

b. Australia ....................................................................... 82

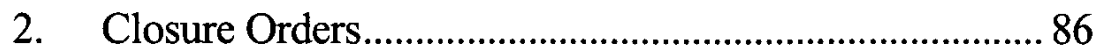

a. The United States ....................................................8

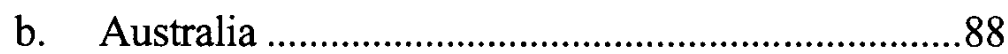

3. Secrecy for Jurors ..........................................................90

a. The United States ...................................................90

b. Australia .................................................................94

V. TRYING TO EXPLAIN THE DIFFERENCES .........................................97

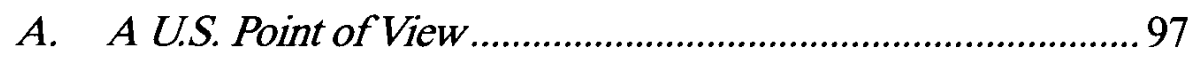

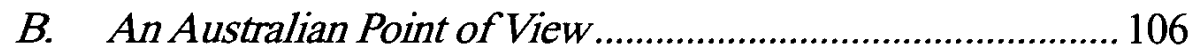

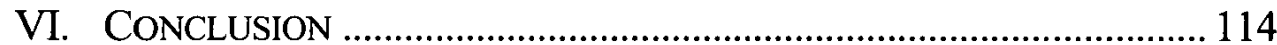

\section{INTRODUCTION}

Australia and the United States of America share a common heritage including close ties to their mother country of England, the same language,' and a genuine sense of connection to one another even though separated by a large ocean and thousands of kilometers or miles (depending on which nation describes the distance). The similarities of our two respective criminal justice systems are particularly striking in many ways. One immediately thinks of rules regarding the investigation of crime, the fact finding process at trial, and the sense of fundamental fairness required for a just procedure. Equally as striking, however, is the lack of similarities between the two systems in significant areas.

1. Well, not exactly the same language. Americans may be surprised to know that, in Australia, sunnies refer to sunglasses while lollies may be any sort of candy. Yet, are those terms any more unusual than the Aussie hearing the Yank say bad when she really means good, or describing something as phat but not meaning weighty? 
Differing views concerning the limits on law enforcement actions, the admissibility of evidence in criminal prosecutions, and the roles of the lawyer and the jury reflect important and noteworthy value judgments which have been made by the people and governments of the two countries.

This Article will explore both the similarities and differences found in the two criminal justice systems. We believe the reader will be struck, as many professionals in the field are, by the quite distinct roads traveled by Australia and the United States. At the end of this Article we will attempt to lay out some thoughts concerning why the two nations have moved in such different ways in areas of great importance for criminal justice.

\section{Nature OF Regulation of CRIMINAL Procedure}

\section{A. In Australia}

The regulation of criminal procedure in Australia occurs on two levels: state and federal. The Commonwealth's Crimes Act of 1914 largely codified federal regulation of criminal procedure. ${ }^{2}$ At the state level, where the majority of criminal activity is investigated and prosecuted, the regulation of criminal procedure is mixed. ${ }^{3}$ Victoria and Queensland have followed the federal lead by codifying their rules of criminal investigation and procedure. ${ }^{4}$ South Australia and New South Wales also substantially regulate criminal procedure statutorily. ${ }^{s}$ The other states rely upon a mixture of the common law and statute.

The statutory and common law rules cover diverse matters such as the power of arrest, ${ }^{6}$ detention, ${ }^{7}$ bail, ${ }^{8}$ interrogation, ${ }^{9}$ forensic examina-

2. To the extent that the Crimes Act, 1914 (Austl.) does not apply, section 68(1) of the Judiciary Act, 1903 (Austl.) applies state and territory laws with respect to arrest, detention, trial procedure, and appeals to federal offenses. Judiciary Act, 1903, $§ 68$ (Austl.)

3. Federal jurisdiction is confined to matters reserved to the Commonwealth under the Constitution. It includes the investigation and prosecution of narcotics offenses involving importation, serious fraud against the Commonwealth, international crimes such as war crimes or trafficking in children for sexual purposes, and terrorism. Other Commonwealth agencies such as the Australian Securities and Investment Commission, the Australian Taxation Office, and the Australian Competition and Consumer Commission have specific jurisdiction in relation to laws they were created to regulate.

4. See Crimes Act, 1958 (Vict.); Police Powers and Responsibilities Act, 2000 (Queensl.). For a comprehensive database of Australian federal and state law, visit the Australasian Legal Information Institute, at http://www.austlii.edu.au/ (last visited Jan. 26, 2004).

5. Crimes Act, 1900, pts. 10, 10A-10B (N.S.W.); Summary Offences Act, 1953, §§ 6583A (S. Austl.).

6. E.g., Police Act, 1927, $\S 19$ (Austl. Cap. Terr.); Crimes Act, 1900, $§ 352$ (N.S.W.); Police Administration Act, 1978, $\S 123$ (N. Terr. Austl.); Criminal Code, 1899, § 546 (Queensl.); 
tion, ${ }^{10}$ and search and seizure. ${ }^{11}$ These rules are generally enforced indirectly through the mechanism of excluding evidence attained as a result of their breach at the trial of criminal defendants. ${ }^{12}$ At common law, courts have discretionary power to exclude evidence that is improperly obtained or that might result in an unfair trial of the accused. ${ }^{13}$

In federal courts, which do not hear serious criminal cases, ${ }^{14} \mathrm{New}$ South Wales courts, Tasmanian courts, and Australian Capital Territory courts, the Evidence Act of 1995 governs admissibility. ${ }^{\text {is }}$ When passed, this Act was intended to operate as a uniform law of evidence throughout Australia. ${ }^{16}$ Subsequently, however, not all states were convinced of the need for reform. Although the Evidence Act of 1995 does not incorporate all the common law rules of evidence, ${ }^{17}$ it operates as a complete code in relation to the rules of admissibility. ${ }^{18}$ In terms of the regulation of criminal procedure, the Evidence Act of 1995 reflects the

Summary Offences Act, 1953, § 75 (S. Austl.); Crimes Act, 1958, § 459 (Vict.); Criminal Code, 1913, § 564 (W. Austl.).

7. E.g., Crimes Act, 1900, pt. 10A (N.S.W.); Police Powers and Responsibilities Act, 2000, § 19 (Queensl.); Summary Offences Act, 1953, § 78 (S. Austl.); Criminal Law (Detention and Interrogation) Act, 1995, § 4 (Tas.); Crimes Act, 1958, § 464A (Vict.).

8. E.g., Bail Act, 1992 (Austl. Cap. Terr.); Bail Act, 1978 (N.S.W.); Bail Act, 1982 (N. Terr. Austl.); Bail Act, 1980 (Queensl.); Bail Act, 1985 (S. Austl.); Bail Act, 1994 (Tas.); Bail Act, 1977 (Vict.); Bail Act, 1982 (W. Austl.).

9. E.g., Crimes Act, 1900, pt. 10A (N.S.W.); Police Administration Act, pt. 7, div. 6A (N. Terr. Austl.); Police Powers and Responsibilities Act, 2000, ch. 7 (Queensl.); Summary Offences Act, 1953, §§ 78-83A (S. Austl.); Criminal Law (Detention and Interrogation) Act, 1995 (Tas.); Crimes Act, 1958, $\S \S 464 B-464 J$ (Vict.); Criminal Code, 1985, $\S \S 570 A-570 G A$ (W. Austl.).

10. E.g., Crimes Act, 1914, pt. 1C (Austl.); Crimes (Forensic Procedures) Act, 2000 (Austl. Cap. Terr.); Crimes (Forensic Procedures) Act, 2000 (N.S.W.); Criminal Law (Forensic Procedures) Act, 1998 (S. Austl.); Crimes Act, 1958, $\S \S 464 Z 464 Z L$ (Vict.).

11. E.g., Crimes Act, 1900, §349ZY (Austl. Cap. Terr.); Crimes Act, 1900, pt. 10B (N.S.W.); Police Administration Act, $\S 144$ (N. Terr. Austl.); Police Powers and Responsibilities Act, 2000, pt. 2 (Queensl.); Summary Offences Act, 1953, $§ 81$ (S. Austl.); Criminal Process (Identification and Search Procedures) Act, 1976 (Tas.).

12. G.L. Davies, Exclusion of Evidence Illegally or Improperly Obtained, 76 A.L.J.R. $170,180-82$ (2002) (arguing that there is no evidence that exclusion has any disciplinary effect on law enforcement officers or that exclusion protects or remedies breaches of rights).

13. See Pavic v. The Queen (1998) 192 C.L.R. 159, 171

14. Australian federal courts have no jury facilities. Criminal breaches of federal law are heard by state courts pursuant to sections 39-39B of the Commonwealth of Australia's Judiciary Act of 1903. Judiciary Act, $1903 \S 39-39 B$ (Austl.).

15. Evidence Act, 1995 (Austl.).

16. See id.

17. For example, it does not determine the allocation of the burden of proof, deal with presumptions, or include the doctrines of estoppel or res judicata. STEPHEN ODGERS, UNIFORM EVIDENCE LAW, at lvii (5th ed. 2002).

18. See Telstra Co. v. Australis Media Holdings [No 2] (1997) 41 N.S.W.L.R. 346, 349-50 (per McLelland, J.). 
common law position: a breach can result in the exclusion of evidence on the basis of unfairness ${ }^{19}$ or impropriety/illegality. ${ }^{20}$

Notwithstanding considerable statutory reform at both the federal and state levels, the meta-themes of criminal procedure are still largely common law based. These meta-themes include:

1. The right to due process ${ }^{21}$

2. The right to legal counsel ${ }^{22}$

3. The right to equal treatment before the law $^{23}$

4. Immunity from involuntary detention without trial ${ }^{24}$

5. Immunity from retrospective operation of criminal laws. ${ }^{25}$

The Australian case law has only recently been enunciated. All of the principles outlined above were pronounced by the High Court in the 1990s. ${ }^{26}$ During this period, the primary focus of the High Court was upon the integrity of the criminal process rather than upon the rights of the accused. While some members of the High Court were prepared to couch their discussion in terms of rights-based jurisprudence, ${ }^{27}$ the majority shied away from that path, preferring to ascribe the development of this relatively new jurisprudence to the Court's inherent power to protect its own processes and to ensure the observance of the rule of law. ${ }^{28}$

The High Court's cautionary approach to these principles might be viewed as the chrysalis of more substantive constitutional criminal procedure in the future. However, the constitutional basis for such a development remains weak and almost wholly reliant on the structural

19. Evidence Act, 1995, $\S 90,135,137$ (Austl.).

20. Id. $\S \S 138-139$.

21. See Leeth v. Commonwealth (1992) 174 C.L.R. 455.

22. See Dietrich v. The Queen (1992) 177 C.L.R. 292.

23. See Polyukhovich v. Australia (1991) 172 C.L.R. 501.

24. Kable v. Dir. of Pub. Prosecutions for the State of N.S.W. (1996) 189 C.L.R. 51. This does not apply in the Territories. See Kruger v. Australia (1997) 190 C.L.R. 1.

25. See Polyukhovich, 172 C.L.R. 501; Kable, 189 C.L.R. 51.

26. The High Court is analogous to the U.S. Supreme Court. It is the final court of appeal in Australia, and also exercises original jurisdiction over interstate and federal versus state matters.

27. E.g., Dietrich, 177 C.L.R. at 326 (per Deane, J.), 362 (per Gaurdon, J.).

28. See Geoffrey de Q. WALKer, The Rule of LAW: Foundation OF CONSTITUTIONAL DEMOCRACY 1-46 (1988) (discussing various meanings of the "rule of law" from legal constraint on governmental action to a set of values encompassing the presumption of innocence, presumption against retroactive legislation, and mandatory trial by jury for serious criminal cases). 
separation of power between the judiciary, the legislature, and the executive as set out in the Commonwealth Constitution. ${ }^{29}$

Therefore, Australia currently stands outside of mainstream developments in constitutional criminal procedure that have occurred in other common law jurisdictions. ${ }^{30}$ Even Britain, the original source of Australian criminal procedural rules, enacted a Human Rights Act in $1998 .^{31}$

\section{B. In the United States}

The bases for the criminal procedure process in the United States are, in some ways, quite similar to those in Australia. As in Australia, the U.S. criminal justice system also is overwhelmingly state oriented, with relatively few crimes prosecuted in the federal courts. ${ }^{32}$ Those cases that are brought forward by U.S. Attorneys tend to be drug oriented, ${ }^{33}$ involve movement across state lines, ${ }^{34}$ or result from specific nationally focused statutes. $^{35}$

Unlike in Australia, where criminal procedure tends to be state based, American criminal procedure is federal, ${ }^{36}$ is not of recent origin, and relies overwhelmingly on constructions of the United States Constitution by federal courts, and-to a lesser extent-state courts. ${ }^{37}$

29. See Kable, 189 C.L.R. 51; Kruger, 190 C.L.R. 1.

30. E.g., U.S. CONST. amends. IV-VI, VIII; The Canadian Charter of Rights and Freedoms (Gérald A. Beaudoin \& Ed Ratushny eds., 2d ed. 1989); Bill of Rights Act, 1990 (N.Z.), available at http://www.oefre.unibe.ch/law/icl/nz01000.html.

31. Human Rights Act, 1998 (Eng.), Richard Clayton \& Hugh TOMLinson, THE Law OF Human RighTS 125 (2000).

32. The states typically process more than ninety percent of all serious crimes in the United States. Jodi M. Brown \& Patrick A. Langen, Felony Sentences in the U.S., 1996, in BuREAU OF Justice STATISTICS BULletiN 2 (July 1999), available at http://www.ojp.usdoj. gov/bjs/pub/pdf/fsus96.pdf.

33. 21 U.S.C. section 846 is the standard federal statute outlawing drug distribution. 21 U.S.C. $\S 846(2000)$.

34. 18 U.S.C. section 1952, generally known as the Travel Act, prohibits traveling in interstate or foreign commerce with intent to commit crimes. 18 U.S.C. $\S 1952$ (2000).

35. The wide reaching Securities and Exchange Act of 1934, for instance, imposes criminal sanctions for providing false or misleading statements in connection with the sale or transfer of securities such as stocks and bonds. 15 U.S.C. $\$ 78 \mathrm{ff}(2000)$.

36. This is not to suggest that states have entirely abandoned the earlier practice of enacting specific (and quite helpful) rules of criminal procedure. For thoughtful illustrations of such rules, see the systems in California and Texas. CAL. PENAL CODE $\S 686$ (West 1999); 4A TEX. CRIM. CODE ProC. ANN. arts. 22, 38 (Vernon 1979). Still, most of the litigation and guidance regarding the critical issues of criminal procedure are federally controlled.

37. Many state courts actively apply federal constitutional provisions due to the concurrent jurisdiction in the two judicial systems. Moreover, many state courts apply their own state constitutional provisions in state criminal cases. This generally occurs in situations which 
Consider, for instance, three of the more prominent examples of these procedures relating to the right to counsel, the rules of exclusion, and the privilege against self-incrimination, as will soon be discussed in greater detail later in the Article.

For a considerable period of time, various states had conflicting requirements regarding lawyers for indigent defendants in criminal cases. ${ }^{38}$ It took the United States Supreme Court's decision in Gideon v. Wainwright, ${ }^{39}$ and later cases, to mandate the right to counsel for virtually all criminal defendants at the critical stages of both federal and state criminal prosecutions. ${ }^{40}$ Similarly, while some states excluded unlawfully obtained evidence in criminal cases prior to the $1960 \mathrm{~s}$, most did not. ${ }^{41}$ Exclusion became the norm in all criminal cases involving violations of the search and seizure provision of the Fourth Amendment with the Supreme Court's decision in Mapp v. Ohio. ${ }^{42}$

The United States Supreme Court's construction of constitutional rights superseded state law and soon dominated the national debate, as seen clearly in the confession cases dealing with the right to remain silent. Once the Court's decision in Miranda v. Arizona was issued in 1966, the debate concerning the application of the privilege against selfincrimination turned almost entirely on issues surrounding Miranda such as definitions of custody, interrogation, and waiver. ${ }^{43}$ Independent state rules on this important point became almost nonexistent. ${ }^{44}$

\section{WE ARE SO VERY MUCH AlIKE}

Whether attending a criminal trial in Melbourne or in Chicago, even the most casual observer will quickly comment on the commonalities of the two processes. Apart from robe and wig (and the occasional

those state constitutional provisions provide at least as much protection for the accused as does the federal constitution.

38. In Gideon $v$. Wainwright, twenty-two states, led by then Minnesota Attorney-General, and later Vice President of the United States, Walter Mondale, filed briefs in opposition to the position taken by the state of Florida in the case. Gideon v. Wainwright, 372 U.S. 335 (1963). These states had requirements similar to those urged by the lawyers for Gideon, and ultimately adopted by the Supreme Court. SeeANTHONY LEWIS, GIDEON's TRUMPET 151-55 (1964).

39. Gideon, 372 U.S. at 344-45.

40. See infra notes 305-316 and accompanying text.

41. See Mapp v. Ohio, 367 U.S. 643, 658-59 (1961).

42. Id.; U.S. CONST. amend. IV; see infra notes 206-234 and accompanying text.

43. Miranda v. Arizona, 384 U.S. 436 (1966).

44. In a highly unusual move, a few states have taken an innovative approach in this area by requiring, in addition to Miranda warnings, the electronic recording of interrogations of all criminal suspects in custody. Without such electronic recording, a resulting confession will generally not be admissible in evidence at trial. See, e.g., State v. Scales, 518 N.W.2d 587 (Minn. 1994); Stephan v. State, 711 P.2d 1156 (Alaska 1985). 
reference to "Your Worship" as opposed to "Your Honor"), the two systems' apparent procedures and substantive rules are virtually identical. This Article now turns to consider a few of the more important similarities.

\section{A. The Golden and Silver Threads: Presumption of Innocence and Proof Beyond a Reasonable Doubt}

Can there be any element more central to criminal justice systems with English origins than the strong presumption of innocence of the defendant, expressed through the government retaining the burden of proving guilt beyond a reasonable doubt? This feature, more than any other, constitutes the core of the criminal justice systems in both the United States and Australia. ${ }^{45}$

The United States Supreme Court has been nothing less than extravagant in its praise of the presumption of innocence, noting that it is "axiomatic and elementary, and its enforcement lies at the foundation of the administration of our criminal law." persuasion rests entirely on the prosecutor. ${ }^{47}$ This burden, proof beyond a reasonable doubt, is a high standard. This requirement, too, plays a key role in the U.S. criminal justice system:

The accused during a criminal prosecution has at stake interests of immense importance, both because of the possibility that he may lose his liberty upon conviction and because of the certainty that he would be stigmatized by the conviction.

…

Moreover, use of the reasonable-doubt standard is indispensable to command the respect and confidence of the community in applications of the criminal law. It is critical that the moral force of the criminal law not be diluted by a standard of proof that leaves people in doubt whether innocent men are being condemned. ${ }^{48}$

The Australian High Court also has written of this foundation of the administration of criminal justice, describing the allocation of the burden

45. The Supreme Court of Canada captured the significance of the two concepts, building on the traditional statements found in virtually all common law countries: "If the presumption of innocence is the golden thread of criminal justice then proof beyond a reasonable doubt is the silver and these two threads are forever intertwined in the fabric of criminal law." R. v. Lifchus, [1997] 3 S.C.R. 320, 332 (Can.).

46. Coffin v. United States, 156 U.S. 432, 453 (1895).

47. Taylor v. Kentucky, 436 U.S. 478, 491 (1978) (Stevens, J., dissenting).

48. In re Winship, 397 U.S. 358, 363-64 (1970). The Court explained further that the "standard is indispensable, for it "impresses on the trier of fact the necessity of reaching a subjective state of certitude of the facts in issue."' Id. at 364 (internal citations omitted). 
of proof beyond a reasonable doubt upon the prosecution as a "fundamental" principle "to eliminate or minimize the chance that an innocent person might be found guilty," given the grave consequences an erroneous guilty verdict would have for the accused, the justice system, and for society generally. ${ }^{51}$ Furthermore, the presumption of innocence is a necessary systemic feature of the adversarial trial. ${ }^{52}$

\section{B. Voluntariness, the Taking of Confessions}

The courts in both nations have long written eloquently of the need to scrutinize carefully the taking of confessions by law enforcement personnel. While Americans now routinely consider the validity of confessions in light of the right to counsel and the privilege against selfincrimination, both systems historically evaluated confessions by the traditional standard of voluntariness. ${ }^{53}$ As the High Court has written:

The argument is that to be admissible evidence of a confession must be an expression of the independent will of the confessionalist and, moreover, must derive from the circumstances in which it is made that assurance of trustworthiness which the law finds in the improbability of a false admission being made of incriminating facts. ${ }^{54}$

U.S. judges also are concerned with whether the interrogated suspect's "will has been overborne and his capacity for selfdetermination critically impaired." 55 The government, in questioning the accused, may not take any action which "breaks the will to conceal or lie ... [or] even break[s] the will to stand by the truth." ${ }^{\text {s6 }}$ Law enforcement officials must perform interrogations in a way that induces only voluntary statements from suspects; they must conduct themselves "'consistent with the fundamental principles of liberty and justice which lie at the base of all our civil and political institutions."

49. Envtl. Prot. Auth. v. Caltex Ref. Co. (1993) 178 C.L.R. 477, 527 (per Dawson, J., Deane, J., \& Gaudron, J.).

50. Sorby v. Australia (1983) 152 C.L.R. 281, 294.

51. Thompson v. The Queen (1989) 169 C.L.R. 1, 12 (per Mason, C.J. \& Dawson, J.).

52. Envtl. Prot. Auth., 178 C.L.R. at 550 (per McHugh, J.) (noting that the presumption of innocence was not necessary in an inquisitorial system).

53. See infra notes 286-302 and accompanying text.

54. Sinclair v. The King (1946) 73 C.L.R. 316, 334-35 (per Dixon, J.).

55. Culombe v. Connecticut, 367 U.S. 568, 602 (1961).

56. Watts v. Indiana, 338 U.S. 49, 60 (1949) (Jackson, J., concurring).

57. Brown v. Mississippi, 297 U.S. 278, 286 (1936) (quoting Hebert v. Louisiana, 272 U.S. $312,316(1926))$. 
The voluntariness standard for admissible statements by criminal defendants has created enormous difficulties in practice ranging from the lack of precedential value of any one decision ${ }^{58}$ to the inconsistencies of courts in making key decisions. ${ }^{59}$ Moreover, it has been the subject of sharp criticism in terms of its extremely narrow focus. ${ }^{60}$ It remains, however, the central standard zealously promoted and protected by both Australian and American judges.

\section{The Role of the Trial Judge}

In a previous discussion, this Article posed whether there could be a feature more essential to the criminal justice systems than the presumption of innocence. If there is one, it might well be the role of the trial judge. Unlike systems in which the judge has prosecutorial responsibilities, ${ }^{61}$ or sits with lay people as part of a fact finding team, ${ }^{62}$ Australian and U.S. judges are viewed as true neutrals with no involvement in the charging process or the fact-determining body. ${ }^{63}$

The language of the courts in both countries is remarkably similar when describing the need to keep judges separate from the other participants in the criminal justice system. The High Court of Australia has determined that justice cannot be done where "the parties or the

58. The point becomes clear when one reviews what is arguably the most important United States Supreme Court decision on voluntariness. Spano v. New York, 360 U.S. 315 (1959). There the Court struck down the admitted-and reliable-confession but only after pointing to not less than ten specific factors which supported the conclusion that the statement of the defendant was not voluntary. Id. at 320-21.

59. One of the most troublesome problems involves the use of deception by law enforcement officers in connection with the interrogation. Some courts allow such lies relating to statements of co-conspirators, possible eyewitnesses, and the general strength of the evidence against the suspect. Other courts, however, are more concerned about such deceptions, particularly if they relate to the process in which the defendant is involved (i.e., the crimes to be charged, the possible sentence, etc.). The Supreme Court has given very little guidance on the subject. See Welsh S. White, Confessions Induced by Broken Government Promises, 43 DUKE L.J. 947, 952-56 (1994); Deborah Young, Unnecessary Evil: Police Lying in Interrogations, 28 CONN. L. REV. 425, 451-56 (1996).

60. Catherine Hancock, Due Process Before Miranda, 70 TUL. L. REv. 2195, 2195-2237

61. In Argentina, for instance, the judge has various prosecutorial tasks such as conducting interrogation and making charging decisions. See Alejandro Carrio \& Alejandro M. Garro, Argentina, in Criminal Procedure: A Worldwide Study 3, 30-47 (Craig M. Bradley ed., 1999).

62. See, for example, China, where the judge sits with lay people as part of a fact finding panel. "[The] lay assessors carrying out their duty have equal rights with judges, they together decide the facts and apply the law." Liling Yue, China, in CRIMINAL PROCEDURE: A WORLDWIDE STUDY, supra note 61 , at 81,87 .

63. Here, of course, this Article refers to trials before a jury rather than to trials in which the judge serves as fact finder. 
public might entertain a reasonable apprehension that the judge might not bring an impartial and unprejudiced mind to the resolution of the matter,",64 Accordingly, to preserve their neutrality, judges should not express views about the cases in front of them outside of the courtroom. Australian judges must never privately confer with the parties or any other person with an interest in the case while the case is still pending. Nor should judges direct the parties to present their case in any particular manner. Judges may not adduce evidence by way of their own motion ${ }^{65}$ and must defer to the parties' strategic choices regarding the presentation of their respective cases. ${ }^{66}$

The United States Supreme Court has repeatedly held, in a similar vein, that the judge in a criminal case must have no "interest in the outcome of his particular case.", The trial judge may not have an undue connection to the prosecution of the case ${ }^{68}$ nor any sort of personal or financial ties to the parties or witnesses. ${ }^{69}$ Such improper connection or tie "deprives a defendant in a criminal case of due process of law,", for the defendant is entitled to a "fair trial in a fair tribunal.""

\section{BUT OH THE DIFFERENCES}

This Article will now turn to the aforementioned differences between the two criminal justice systems. There are a number of sharp contrasts.

\section{A. Search and Seizure}

Central to any modern criminal justice system is the set of rules and practices concerning government searches and seizures of citizens. In this broad area there are considerable differences between Australia and the United States. These differences are particularly vivid when one evaluates separately the wide privacy considerations, and the remedies for dealing with inappropriate government actions, identified by judges in both countries.

64. Grassby v. The Queen (1989) 168 C.L.R. 1, 20 (per Dawson, J.).

65. The power to call witnesses should only be used in extreme cases to avoid a miscarriage of justice. See The Queen v. Apostilides (1984) 154 C.L.R. 563.

66. Id. at $575-77$.

67. Bracy v. Gramley, 520 U.S. 899,905 (1997).

68. Taylor v. Hayes, 418 U.S. 488,501 (1974).

69. Tumey v. Ohio, 273 U.S. 510, 523 (1927).

70. Id.

71. Bracy, 520 U.S. at 904. 


\section{Australia}

A plethora of statutory provisions governs the regulation of search and seizure in Australia. These provisions range from specific powers applicable to particular criminal activities ${ }^{72}$ or to a particular investigative body, ${ }^{73}$ to broad powers applicable whenever reasonable suspicion is aroused. ${ }^{74}$

The statutory provisions generally grant powers rather than protection and result from the common law of trespass that would otherwise apply to render search and seizure unlawful. ${ }^{75}$ Their raison d'être is thus to facilitate police investigation rather than to protect individuals from undue interference. ${ }^{76}$

Australia has no constitutional protection against unreasonable search and seizure like the United States' Fourth Amendment." Consequently, in Australia, the thematic tensions between the right to privacy and responsible police investigation that dominate U.S. jurisprudence are sublimated within a process of statutory interpretation. The High Court premises such statutory interpretation on the idea that unambiguous statutory language is required in order to abrogate common

72. See Classification (Publications, Films and Computer Games) Enforcement Act, 1995 (N.S.W.); Unlawful Gambling Act, 1998 (N.S.W.); Poisons and Therapeutic Goods Act, 1966 (N.S.W.); Drug Misuse and Trafficking Act, 1985 (N.S.W.); Classification of Publications Act, 1991 (Queensl.); Classification of Films Act, 1991 (Queensl.); Classification of Computer Games and Images Act, 1995 (Queensl.); Classification (Publications, Films and Computer Games) Act, 1995 (S. Austl.) (allowing search, warrant, and subsequent seizure for any offense suspected of contravening the act); Controlled Substances Act, 1984 (S. Austl.) (authorizing search and seizure of drugs); Firearms Act, 1977 (S. Austl.); Poisons Act, 1971 (Tas.); Firearms Act, 1996 (Tas.); Classification (Publications, Films and Computer Games) Enforcement Act, 1995 (Vict.); Lotteries Gaming and Betting Act, 1966 (Vict.); Firearms Act, 1996 (Vict.); Fisheries Act, 1995 (Vict.) (allowing wide ranging powers for police or authorized offices to enter, search, and seize objects in relation to the act); Betting Control Act, 1954 (W. Austl.) (authorizing police to stop, search, and seize anything in relation to betting); Misuse of Drugs Act, 1981 (W. Austl.); Firearms Act, 1973 (W. Austl.) (allowing police to obtain a warrant and search premises or to stop and search vehicles). These statutes can all be located through the Australasian Legal Information Institute, available at http://www.austlii.edu.au/.

73. E.g., New South Wales Crime Commission Act, 1985, §11 (N.S.W.); Health Act, 1937 (Queensl.).

74. E.g., Police Powers and Responsibilities Act, 2000, §§ 19, 28-29 (Queensl.); Summary Offences Act, 1953, 67 (S. Austl.); Police Offences Act, 1935, §§ 57, 60 (Tas.); Police Act, 1892, §49 (W. Austl.).

75. See Plenty v. Dillon (1991) 171 C.L.R. 635, 644; Entick v. Carrington (1765) 95 E.R. 807; Semayne v. Gresham (1604) 77 E.R. 194. However, note that the use of sniffer dogs does not constitute an unlawful trespass. Consequently, no statutory power is required to permit sniffer dogs to seek the scent of contraband. Question of Law Reserved [No. 5] (1998) 71 S.A. St. R. 222.

76. See George v. Rockett (1990) 170 C.L.R. 104, 110.

77. U.S. CONST. amend. IV. 
law rights to freedom from interference to property and person (provided the legislature's intention to do so is clear) ${ }^{78}$ The Court's role largely is confined to determining whether the investigative activity at issue falls within the scope of the relevant statutory provision.

Nonetheless, the courts tend to read strictly the statutory provisions authorizing search and seizure ${ }^{79}$ so that activity falling outside the scope of the provisions will be regarded as unlawful, enlivening the discretion to exclude evidence illegally or improperly obtained. ${ }^{80}$

Compared to their approach to the statutory regulation of interrogation, Australian courts take a fairly pedantic view of the provisions regulating search and seizure. Thus, the common law tenet that "a man's home is his castle" appears to have a stronger resonance in Australian jurisprudence then concerns regarding overzealous police activity during interrogation.

Depending on context and jurisdiction, searches may be undertaken without a specific warrant. For example, in South Australia and Queensland, police have a general power to search persons and vehicles when they have a reasonable suspicion that they will find evidence of a criminal offense. ${ }^{81}$ Statutes in other jurisdictions permit the search of persons and premises without a warrant following arrest on the basis that arrest requires police to have a reasonable suspicion of participation in a criminal offense. ${ }^{82}$

However, these general powers fall short of authorizing Australian law enforcement officials to stop, search, and seize on any pretext. ${ }^{83}$ Coleman v. Zanker is a typical example of the court's strict approach to

78. The High Court has expressed the view that fundamental rights to privacy and other civil liberties should not be abrogated without clear statutory language. Coco v. The Queen (1994) 179 C.L.R. 427, 437-38. Carbone v. Police confirmed the constitutional validity of general powers of search and seizure. Carbone v. Police (1997) 68 S.A. S.R. 200.

79. E.g., R. v. Turner (2001) 161 F.L.R. 451; Cassaniti v. Croucher (2000) 48 N.S.W.L.R. 623; R. v. EID (1999) 46 N.S.W.L.R. 116; Fernando v. Comm'r of Police (1995) 36 N.S.W.L.R. 567; Swanevelder v. Holmes (1990) 52 S.A. S.R. 549; Esso Austl. Ltd. v. Curran (1989) 38 A. Crim. R. 157.

80. See Bunning v. Cross (1978) 141 C.L.R. 54, 64.

81. Police Powers and Responsibilities Act, 2000, $\S \S 27-30$ (Queensl.); Summary Offences Act, 1953, § 68 (S. Austl.); see also Henry Aizen \& Rad Saunders, Search Warrants: A Practical Guide, 9 LAW INST. J., 48, 49-50 (2000) (containing a list of twenty-four statutory provisions that permit searches without warrant in the state of Victoria).

82. Crimes Act, 1900, § 353A (N.S.W.); Criminal Code, 1985, § 712 (W. Austl.); Police Offences Act, 1935, $\S 58 \mathrm{~B}$ (Tas.).

83. See, e.g., R. v. Hudson (1996) 189 L.S.J.S. 522; R. v. Prinz No 1 (2002) 223 L.S.J.S. 299; R. v. Gibson (2000) S.A. Dist. Ct. 80; R. v. Davidson (1991) 54 S.A. St. R. 580 . Note that where police act pursuant to both specific and general statutory powers of search and seizure, the provisions are to be read together and the use of a specific power does not exclude reliance on the more general power. See also Gibson v. Ellis (1992) 40 S.A. St. R. 420, 425. 
the requirement of "reasonable suspicion." ${ }^{84}$ In that case police approached two men on a street late at night who were in a vehicle. ${ }^{85}$ The police told the defendant, at the time seated inside the vehicle, to get out of the vehicle. ${ }^{86}$ As the defendant was alighting the vehicle, one of the police officers shone her torch into the vehicle and claimed to see a knife. ${ }^{87}$ The police then physically searched the vehicle and produced the knife. ${ }^{88}$ Subsequently, the defendant was charged with and convicted of carrying an offensive weapon. ${ }^{89}$ The defendant appealed to the South Australian Supreme Court. ${ }^{90}$ The appellate judge found that both the police officer's demand that the defendant leave the vehicle and the examination of the vehicle by torchlight were unlawful. ${ }^{91}$ The Court reasoned that the police officer concerned had no basis for suspecting that the defendant committed a crime nor did she have any evidence of the commission of a crime by the defendant other than the fact that he was in the company of another man and they were on the street late at night. ${ }^{92}$ As a result, the appellate judge found that the evidence of the knife should have been excluded and quashed the defendant's conviction. $^{93}$

Where there is no general power of search and seizure, a search warrant authorizing police or other investigative authorities will have to be issued under Australian law. ${ }^{94}$ Magistrates or justices usually issue warrants. ${ }^{95}$ There must be reasonable grounds for believing or suspecting that the premises or the person to be searched will contain evidence of an

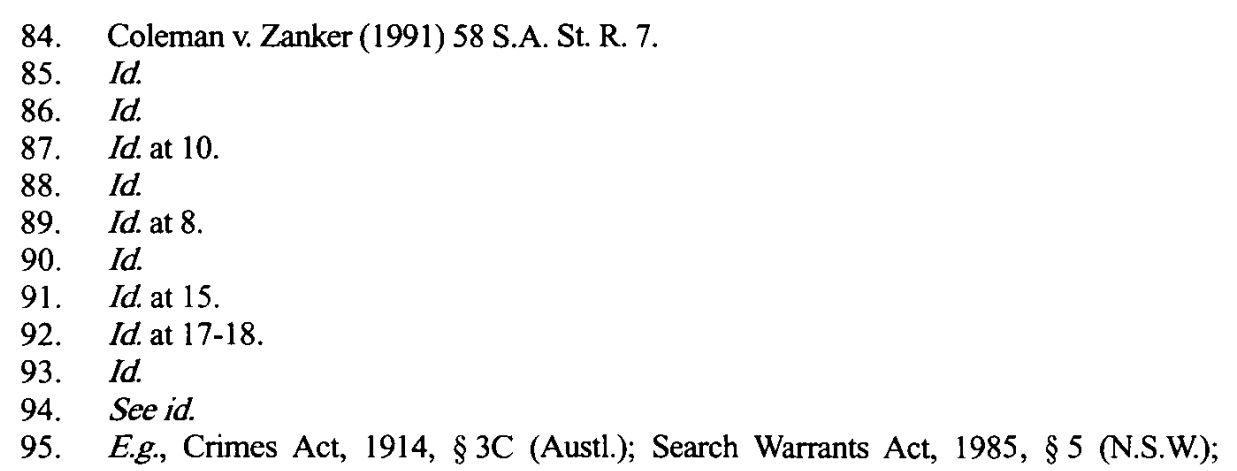
Search Warrants Act, 1997, $\$ 5$ (Tas.); Police Regulation Act, 1958, §100A (Vict.); Criminal Code, 1985, $\S 711$ (W. Austl.); Police Powers and Responsibilities Act, 2000, §68 (Queensl.) (stating that where there is structural damage to a building, the warrant must be authorized by a Supreme Court Justice). The issue of a warrant is regarded as an administrative rather than a judicial act, and consequently is subject to judicial review. Ousley v. The Queen (1997) 192 C.L.R. 69. The validity of a search warrant may also be challenged collaterally on a voir dire inquiry during criminal proceedings. See Love v. Attorney-Gen. for N.S.W. (1990) 169 C.L.R. 307, 322-23; Coco v. The Queen (1994) 179 C.L.R. 427, 444; Ousley, 192 C.L.R. at 1554-46. 
offense sufficient to justify the issue of the warrant. ${ }^{96}$ Often an applicant must provide an affidavit setting out the factual details giving rise to the requisite state of mind in order to satisfy this requirement. ${ }^{97}$

Exclusion of evidence obtained by way of an illegal search and seizure remains at the discretion of the court. In exercising this discretion, the trial judge is required to balance the need to convict the guilty against the need to condemn police misconduct. Relevant factors in the balancing exercise include: ${ }^{98}$

1. Seriousness of the crime ${ }^{99}$

2. Deliberateness of the police misconduct ${ }^{100}$

3. Relationship between the illegality and the cogency of the evidence $^{101}$

4. The ease with which evidence could have been obtained if police had complied with the law

5. The policy underlying the relevant regulation ${ }^{102}$

In a recent empirical study of the power to exclude illegally or improperly obtained evidence, Bram Pressor concluded that Australian

96. E.g., Crimes Act, 1914, § 3E (Austl.); Search Warrants Act, 1985, § 6 (N.S.W.); Police Powers and Responsibilities Act, 2000, $\S 69$ (Queensl.); Search Warrants Act, 1997, $\S 5$ (Tas.); Police Regulation Act, 1958, § 100A (Vict.); Criminal Code, 1985, § 711 (W. Austl.). This requires the "existence of facts which are sufficient to induce that state of mind in a reasonable person." George v. Rockett (1990) 170 C.L.R. 104, 112. However, absent sufficient evidence before the court to demonstrate that the beliefs held were not reasonable, the warrant is presumed to be valid. Ousley 192 C.L.R. at 1554-56; Carroll v. Attorney-Gen. for N.S.W. (1993) 70 A. Crim. R. 162.

97. This will require more than vague references to information received from anonymous informants. If the information received forms the basis for a reasonable belief or suspicion, the affidavit should refer to the underlying facts that caused the police officer to conclude that the information was reliable. See KeIth Tronc ET al., SEarch and SeIzURE IN Australia AND NEw ZEALAND 231-33 (1996); see also R. v. Macleod (1991) 61 A. Crim. R. 465; El-Zarw v. Nikola, Ex parte El-Zarw (1992) 1 Q.R. 145. Some statutory provisions allow for emergency telephone applications for warrants, e.g., Search Warrants Act, 1985, $\S 12$ (N.S.W.). However, these are exceptional and reserved for urgent cases. See Comm'r of Police v. Atkinson (1991) 23 N.S.W.L.R. 495.

98. These factors are relevant both at common law and pursuant to jurisdictions which apply the Evidence Act, 1995 (Austl.), i.e., federal courts, New South Wales courts, Australia Capital Territory courts, and Tasmanian courts. Evidence Act, 1995, § 138 (Austl.).

99. The more serious the crime, the less inclined the court is to exclude illegally obtained evidence. See R. v. Macleod (1991) 61 A. Crim. R. 465, 477; R. v. Addabbo (1982) 33 S.A. St. R. 84, 98 .

100. If police have made an innocent mistake in interpreting the breadth of their powers, the less inclined the court will be toward excluding the illegally obtained evidence. R. v. Nicholas (2000) I V.R. 356. Conversely, deliberate disregard of statutory rights will more likely lead to exclusion. R. v. Wilson (1987) 47 S.A. St. R. 287; Pollard v. R. (1992) 110 A.L.R. 385.

101. See R. v. Olejarnik (1994) 72 A. Crim. R. 542.

102. See Edelsten v. Investigating Comm. of N.S.W. (1986) 7 N.S.W.L.R. 222. 
judges were generally reluctant to exercise their exclusionary powers following a finding that evidence had been illegally or improperly obtained. ${ }^{103}$ Pressor found that this reluctance was especially acute in drug related and serious criminal cases. ${ }^{104} R$. v. Daley illustrates these views. ${ }^{105}$ Daley involved illegally obtained DNA evidence that linked the defendant with several rapes. ${ }^{106}$ The police pulled over the defendant, who had already been identified as a suspect for the rapes ostensibly for the purpose of random breath testing. ${ }^{107}$ Under the ruse of pursuing the matter that the defendant's vehicle was unregistered and uninsured, the police arrested the defendant and drove him to a local police station where he performed a breath analysis test. ${ }^{108}$ The officers obtained a sample of the defendant's DNA from the container used to perform the breath test. ${ }^{109}$ The sample yielded a positive link to the rapes and led to further investigations. ${ }^{10}$ The court, however, found that the police had not acted improperly when using their power to stop drivers and undertake random breath testing for the extraneous purpose of obtaining evidence against the defendant. ${ }^{111}$ Further the court held that even if the police had acted improperly, the evidence from the breath test should not be excluded for the following reasons:

(1) the defendant was in fact guilty of the offenses for which he was arrested and detained;

(2) the police had reason to believe that there was a danger that he would attack again;

(3) there was nothing in the manner in which the evidence was obtained that was likely to affect its cogency adversely;

(4) there was only minimal personal intrusion involved in obtaining the sample; and

(5) the evidence to be obtained was such that it was likely to confirm police suspicions and justify an arrest on the major charges, or to eliminate the accused from the enquiry. ${ }^{112}$

103. Bram Presser, Public Policy, Police Interest: A Re-Evaluation of the Judicial Discretion to Exclude Improperly or Illegally Obtained Evidence, 25 MELB. U. L. REV. 757, 777 (2001).

104. Id.

105. See R. v. Daley (2001) N.S.W.S.C. 1211.

106. Id. para. 114

107. Id. para. 94.

108. Id.

109. Id.

110. Id. paras. 95-103.

111. Id. para. 112.

112. Id. para. 118. 
Australian courts have stopped short of adopting the "fruit of the poisonous tree" doctrine applied by their U.S. counterparts. ${ }^{113}$ Australian courts require a direct relationship between the illegal or improper conduct and the evidence adduced to justify its exclusion from the court. $^{114}$ However, there is some overlap between the fruit of the poisonous tree doctrine and the discretion to exclude confessional evidence for unfairness, especially where the search and seizure was accompanied by an unlawful arrest. ${ }^{115}$

Thus, although Australian courts tend to strictly read search and seizure statutes, they often fail to exclude evidence from a criminal trial that breaches the scope of those provisions. ${ }^{116}$ This reflects a pragmatic view that police investigation should not be unduly restricted if it produces appropriate outcomes. Therefore, Australia gives priority to the need to maintain law and order over individual rights to privacy.

\section{United States}

Over the past forty years, American judges have been far more sensitive to concerns regarding invasions of privacy by physical intrusion than at any other time in the history of American jurisprudence. A few illustrations make the point clearly. Most famous, perhaps, is the litigation surrounding stop and frisk. ${ }^{117}$ This concept refers to the situation in which police officers, normally on routine patrol and without prior warning, come across individuals engaging in suspicious behavior, but behavior which is not sufficiently troubling to justify arrest. ${ }^{118}$

Terry v. Ohio is the case in which the United States Supreme Court dealt directly with the government's contention that actions by law enforcement which were less intrusive than an arrest simply did not raise issues under the Fourth Amendment's "right of the people to be secure in their persons, houses, papers, and effects, against unreasonable searches and seizures." 119 In Terry, the police officer observed three men engaged in suspicious behavior; they appeared to be "casing" a store after hours,

113. See United States v. Ceccolini, 435 U.S. 268 (1978); Michigan v. Tucker, 417 U.S. 433, 445-46 (1974); Wong Sun v. United States, 371 U.S. 471 (1963).

114. See Question of Law Reserved [No 1] (1998) 70 S.A. St. R. 281.

115. See F.E. Devine, American Exclusion of Unlawfully Obtained Evidence with Australian Comparison, 13 CRIM. L.J., 188, 196 (1989) (citing Director of Prosecutions Reference [No 1] (1984) V.R. 727; R. v. Tilev (1983) 33 S.A. St. R. 334; R. v. Lavery (1979) 20 S.A. St. R. 430; McDermott v. R. (1948) 76 C.L.R. 501).

116. See supra notes 104-113 and accompanying text.

117. Terry v. Ohio, 392 U.S. 1 (1968).

118. See id.

119. Terry, 392 U.S. at 9; U.S. CONST. amend. IV. 
presumably to engage in some sort of break-in. ${ }^{120}$ The officer stopped and questioned the subjects; when they did not give a sensible answer, he patted them down, felt a weapon, and took out the illegally concealed pistol. $^{121}$

The defendants moved to suppress the pistol and asserted that their Fourth Amendment rights had been violated because at the time of the stop there was no warrant and no probable cause to stop them. ${ }^{122}$ In response, the government argued that the Fourth Amendment did not apply to such limited actions by the officer. ${ }^{123}$ The Court dealt harshly with this argument:

It must be recognized that whenever a police officer accosts an individual and restrains his freedom to walk away, he has "seized" that person. And it is nothing less than sheer torture of the English language to suggest that a careful exploration of the outer surfaces of a person's clothing all over his or her body in an attempt to find weapons is not a "search." Moreover, it is simply fantastic to urge that such a procedure performed in public by a policeman while the citizen stands helpless, perhaps facing a wall with his hands raised, is a "petty indignity." It is a serious intrusion upon the sanctity of the person, which may inflict great indignity and arouse strong resentment, and it is not to be undertaken lightly. ${ }^{124}$

Recognizing the privacy values at the heart of the Fourth Amendment, the Court fashioned a balancing test which would preserve the privacy of the individual, yet allow for responsible and safe police investigation. ${ }^{125}$ As long as the intrusion of the suspect was limited to a stop and a pat down of his outer garments for purposes of discovering weapons, ${ }^{126}$ officers could conduct the frisk without a warrant, based on an individualized reasonable suspicion, which could be less than probable cause. ${ }^{127}$

The Court's less celebrated opinion, Arizona v. Hicks, ${ }^{128}$ demonstrates this sensitivity to privacy concerns. Earlier decisions had

120. The suspects made "roughly a dozen trips" walking up and back in front of the store. Terry, 392 U.S. at 6.

121. Id. at 6-7.

122. Id. at 8 .

123. Id. at 16.

124. Id. at 16-17.

125. Id. at 30 .

126. The courts take the limitation of a pat-down seriously. It is not to be a full blown search: the suspects cannot be ordered to empty their pockets and the officers cannot scrounge though bags. Minnesota v. Dickerson, 508 U.S. 366, $377-78$ (1993). Indeed, the limitation does not even permit the officers to manipulate contents inside pockets by moving their fingers on the outside of the clothing. Id. at 379-80 (Scalia, J., concurring).

127. Terry, 392 U.S. at 20-22, 27, 30-31.

128. Arizona v. Hicks, 480 U.S. 321 (1987). 
held that officers conducting a valid search could seize clearly illegal goods found openly-in plain view-during the lawful scope of that search. ${ }^{129}$ The officers in Hicks, while properly executing a valid search warrant, came upon two sets of expensive stereo components which seemed out of place in, as Justice Scalia wrote, "the squalid and otherwise ill-appointed four-room apartment." ${ }^{, 130}$ In order to determine if the equipment was stolen, one officer moved some of the components to read the serial number; upon phoning in the number, he was advised that the equipment was stolen. ${ }^{131}$ The officer seized the component and arrested the defendant. ${ }^{132}$ The dissenting Justices dismissed the defense's view that the movement of the stereo was an improper invasion of privacy. ${ }^{133}$ Calling the action here "a cursory inspection" and not a "fullblown search of evidence," they found no impropriety in the officers' actions. ${ }^{134}$

The majority in Hicks strongly disagreed. ${ }^{135}$ They made clear that officers, even when executing a valid warrant, may not move private, personal property unrelated to the warrant, for such action

produce[d] a new invasion of ... privacy unjustified by [any] exigent circumstance.... [T]he "distinction between 'looking' at a suspicious object in plain view and 'moving' it even a few inches" is much more than trivial for purposes of the Fourth Amendment. It matters not that the search uncovered nothing of any great personal value to [the suspect]serial numbers rather than (what might conceivably have been hidden behind or under the equipment) letters or photographs. A search is a search, even if it happens to disclose nothing but the bottom of a turntable. ${ }^{136}$

Hicks and Terry are not the only cases that recognize substantial privacy interests that do not necessarily yield to otherwise legitimate concerns of effective law enforcement, even in cases in which the intrusion on privacy is minimal. ${ }^{137}$ Courts in the United States do screen

129. See, e.g., Coolidge v. New Hampshire, 403 U.S. 443 (1971).

130. Hicks, 480 U.S. at 323.

131. Id.

132. Id.

133. Id. at 325 .

134. Id. at 335 (O'Conner, J., dissenting).

135. Id. at 325 .

136. Id.

137. One could, for instance, also discuss the following decisions to support the notion of the United States Supreme Court's willingness to recognize strong privacy interests in this area: Franks v. Delaware, 438 U.S. 154 (1978) (holding defendant may challenge truthfulness of statements in affidavit relied upon in issuing warrant); Winston v. Lee, 470 U.S. 753 (1985) (finding state cannot compel minor surgery of suspect in order to retrieve evidence); Dunaway v. 
and carefully consider privacy interests, and it may fairly be said that they are loathe to intrude upon them. Still, it is wise to remember that the U.S. courts are not always so considerate in recognizing these interests and not nearly so abrupt in acknowledging concerns of the law enforcement community.

\section{a. The Drug War}

In recent years especially, U.S. courts have been extremely solicitous of the executive branch in terms of construing the Constitution to allow ever more intense battles in the drug war. ${ }^{138}$ One of the most striking examples is the "fly-over" case, California v. Ciraolo. ${ }^{139}$ Here, government officers, responding to an anonymous phone tip about marijuana growing in the defendant's backyard, sought to observe activities in the yard, but a fence that completely enclosed the yard thwarted their efforts. ${ }^{140}$ Undaunted, the officers secured a private plane and flew over the house at an altitude of 1000 feet. ${ }^{141}$ The officers "readily identified marijuana plants 8 feet to 10 feet in height growing $\ldots$ in [the] yard" and photographed the property. ${ }^{142}$ The defendant contended that he had an expectation of privacy in his backyard and that the officers needed to secure a search warrant before looking into the yard from above. ${ }^{143}$ The Supreme Court disagreed, for "[a]ny member of the public flying in this airspace who glanced down could have seen everything that these officers observed .... [The defendant's] expectation that his garden was protected from such observation is unreasonable and is not an expectation that society is prepared to honor."144

New York, 442 U.S. 200 (1979) (questioning of suspect at police station must be based on probable cause); Richards v. Wisconsin, 520 U.S. 385 (1997) (holding officers must generally knock and announce their intentions before executing a search warrant); Florida v. J.L., 529 U.S. 266 (2000) (ruling an anonymous tip, by itself, insufficient to justify stop and frisk).

138. California v. Acevedo, 500 U.S. 565, 601 (1991) (Stevens, J. \& Marshall, J., dissenting) (stating no warrant needed for search of package in car). The dissenting Justices complained about this approach. "No impartial observer could criticize this Court for hindering the progress of the war on drugs. On the contrary, decisions like the one the Court makes today will support the conclusion that this Court has become a loyal foot soldier in the Executive's fight against crime." Id. at 601.

139. California v. Ciraolo, 476 U.S. 207 (1986).

140. Id. at 208-09.

141. Id.

142. Id. at 209.

143. Id. at 211 .

144. Id. at 213-14. The Court reaffirmed the decision in Florida v. Riley. Florida v. Riley, 488 U.S. 445,445 (1989) (allowing surveillance, without a warrant, by use of a helicopter hovering 400 feet above the defendant's property). 


\section{b. Organized Crime}

One especially useful tool to combat organized crime has been the "planted informer," the undercover individual sent in to gather evidence against a crime figure including the individual's own incriminating statements. Because the activity normally takes place prior to any formal charge, the Sixth Amendment right to counsel does not apply. ${ }^{145}$ The key question, then, is whether the Fourth Amendment search and seizure provision requires warrant authorization, especially when the suspected person has been "targeted" by the government. ${ }^{146}$

Utilizing an assumption of the risk sort of argument, the Supreme Court has consistently rejected the defense's Fourth Amendment contention. ${ }^{147}$ In the famous Jimmy Hoffa case, an undercover agent visited Hoffa on several occasions and reported Hoffa's statements to federal agents. ${ }^{148} \mathrm{He}$ later testified against Hoffa at the trial. ${ }^{149}$ The Court affirmed the government's conduct, noting that "[n]either this Court nor any member of it has ever expressed the view that the Fourth Amendment protects a wrongdoer's misplaced belief that a person to whom he voluntarily confides his wrongdoing will not reveal it."150 The Court later extended its ruling to include recorded conversations between the accused and a government agent. ${ }^{151}$

\section{c. Drunk Driving}

In recognition of the extremely serious problems Americans face with accidents and deaths caused by intoxicated drivers, U.S. courts have made accommodations for law enforcement as to stopping and testing

145. See Kirby v. Illinois, 406 U.S. 682 (1972).

146. Of course, other legal issues may also apply, such as the entrapment defense if the agent becomes too entwined in the creation or functioning of the criminal enterprise. See infra notes 340-354 and accompanying text.

147. The assumption of the risk doctrine is standard in the law of torts. As explained by the court in Frey v. Harley Davidson, 734 A.2d 1, 6, 11 n.8 (Pa. Super. 1999):

A plaintiff has voluntarily assumed the risk where he fully understands it and voluntarily chooses to encounter it.

.. The same policy of the common law which denies recovery to one who expressly consents to accept a risk will, however, prevent his recovery in such a case.

Id. (quoting Childers v. Power Line Equip. Rentals, Inc., 681 A.2d 201, 208 (Pa. 1996)).

148. Hoffa v. United States, 385 U.S. 293, 296 (1966).

149. Id.

150. Id. at 302 .

151. See United States v. White, 401 U.S. 745 (1971). The recording in this case took place on radio equipment concealed on the agent and then transmitted to officers. Id. at 747 . 
drivers on the open road. ${ }^{152}$ Officers do not need a warrant nor have formed any level of suspicion prior to the stop. ${ }^{153}$ There are limitations on the officer's discretion. The stops must be done randomly, the stops must be limited to intoxication bases, and the intrusions must normally be narrow in time and scope. ${ }^{154}$

\section{d. Searches of Public School Children}

Considering the growing concerns for the safety of children in public schools, it is surprising that the Supreme Court has spoken only once, almost twenty years ago, about searches in such settings. ${ }^{155}$ In New Jersey v. T.L.O., a school administrator searched a student without a warrant and with an individualized suspicion that fell below the standard of probable cause. ${ }^{156} \mathrm{He}$ found marijuana in the student's purse, and the prosecution subsequently used this marijuana in the criminal case against the student. ${ }^{157}$ The student claimed that without a warrant, and certainly without probable cause, the school administrator had violated her constitutional rights. ${ }^{158}$ Once again, the Supreme Court sided with the government. ${ }^{159}$ The Court's view was that schools are different from the usual criminal justice setting, hence a reasonable search under the Fourth Amendment should also be different. ${ }^{160}$ The Court mandated only a showing of reasonable suspicion and allowed the warrantless search, the seizure of the marijuana, and its use in a criminal proceeding unrelated to the school rules. ${ }^{161}$

152. No one can dispute the magnitude of the drunk driving problem or the states' interest in eradicating it. Media reports of alcohol-related death and mutilation on the nation's roads are legion. The statistics confirm this: "Drunk drivers cause an annual death toll of over $25,000 \ldots$ and in the same time span cause nearly one million personal injuries and more than five billion dollars in property damage."' Mich. Dep't of State Police v. Sitz, 496 U.S. 444, 451 (1990) (quoting 4 Wayne LaFave, Search and Selzure: A Treatise on the Fourth amendment $\S 10.8(\mathrm{~d})(2 \mathrm{~d}$ ed. 1987)).

153. See id. at $450-51$.

154. See id.

155. This only refers to activities directly related to the functioning of the criminal justice system, evidence which will be used in criminal prosecutions. It excludes, for instance, the drug testing of students.

156. New Jersey v. T.L.O., 469 U.S. 325,325 (1985).

157. Id.

158. Id.

159. Id. at 326.

160. Id.

161. The reasonable suspicion standard is taken from the earlier Terry stop and frisk decision. T.L.O., 469 U.S. at 341 (citing Terry, 392 U.S. at 20); see also supra notes 119-127 and accompanying text. The Court in T.L.O. goes on to state that

[t] he warrant requirement, in particular, is unsuited to the school environment .... ... 


\section{e. Plain View Doctrine}

The notion of a plain view exception to the warrant and probable cause requirements of the Fourth Amendment appears to express nothing more than a common sense reading of the values expressed by the founders of the United States in the Bill of Rights. After all, if an officer stumbles across and simply observes incriminating evidence that is clearly uncovered and in plain view, no reasonable expectation of privacy would be violated by having the officer testify to what she has seen or, in some circumstances, has seized. ${ }^{162}$ The difficulty, however, relates to the manner in which the doctrine is construed to apply to an officer who "stumbles" across the evidence. ${ }^{163}$ Suppose that the officer does not "inadvertently" come across the evidence. Rather, the officer knows that she may encounter the evidence while conducting a lawful search directed for other evidence.

This problem normally arises when officers properly executing a search warrant come upon illegal contraband in plain view. The officers knew earlier of the contraband (or at least strongly suspected it), but they did not mention it in the warrant request. In such a situation, the Court has held, the item could be validly seized and ultimately introduced into evidence at the defendant's criminal trial. ${ }^{164}$ The Court reasoned that "even though inadvertence is a characteristic of most legitimate 'plain view' seizures, it is not a necessary condition."

\section{f. Consent}

It has always been the rule in the United States that individuals can give up constitutional rights through consent and/or waiver. ${ }^{166}$ Defendants often dispense with the rights to counsel, jury trial, appeal, and speedy trial, along with the central privilege against self-

... [T] ]he legality of a search of a student should depend simply on the

reasonableness, under all the circumstances, of the search ....

....

... [S] [ are reasonably related to the objectives of the search and not excessively intrusive in light of the age and sex of the student and the nature of the infraction. T.L.O., 469 U.S. at 340-42.

162. See Arizona v. Hicks, 480 U.S. 321, 323-25 (1987); supra notes 128-136 and accompanying text.

163. Hicks, 480 U.S. at 323-25.

164. See Horton v. California, 496 U.S. 128 (1990).

165. Id. at 130 .

166. See, e.g., Bumper v. North Carolina, 391 U.S. 543 (1962) (relating to consent to search); Adams v. United States ex rel. McCann, 317 U.S. 269 (1942) (relating to waiver of jury trial). 
incrimination on a regular basis. If the right is the individual's, then it is the individual's decision whether to exercise or relinquish that right, as long as he does so voluntarily, without hint of coercion or confusion. ${ }^{167}$ Therefore, if waiver is permissible for these legal guarantees, it is not surprising that waiver is also permissible for the search warrant requirement. With some of these rights, however, before the court will consider the relinquishment to be valid, the individual must carefully be advised of the nature of the right so that the decision can be judged as both voluntary and measured. ${ }^{168}$ The question remaining under the Fourth Amendment is whether an officer must also give such advice or warning.

In contrast to the required warnings for other rights, an officer conducting a search is not obliged to advise the suspect of the right to refuse the request for a search. ${ }^{169}$ While the trial judge may consider the failure to advise and the suspect's lack of knowledge in determining whether the defendant voluntarily gave the consent, it is fair to say that judges routinely make findings of voluntariness when the suspect has been told nothing of her constitutional rights. ${ }^{170}$ The Supreme Court has stressed this point.

While knowledge of the right to refuse consent is one factor to be taken into account, the government need not establish such knowledge as the sine qua non of an effective consent.

....

[I]t would be thoroughly impractical to impose on the normal consent search the detailed requirements of an effective warning. ${ }^{171}$

167. See, e.g., North Carolina v. Butler, 441 U.S. 369 (1979) (relating to waiver of the right to counsel).

168. With the right to counsel at trial, the trial judge must inform the defendant, on the record, of the right to proceed with an attorney and further advise of the risks present with going forward pro se. See People v. Klessig, 564 N.W. 2d 716 (Wis. 1997). A guilty plea, which gives up the opportunity for a public trial, will only be valid if the defendant appears before the trial judge and discusses the ramifications of the plea. A detailed mandate found in Illinois Supreme Court Rule 402 requires the defendant to be informed of the nature of the charge, the minimum and maximum sentences prescribed by law, the fact that the defendant has the right to plead not guilty and if she does there will not be any sort of trial. $36 \mathrm{Ill} .2 \mathrm{~d} \mathrm{R}$. 402 . Moreover, all this information, including any plea agreement, must be laid out in open court on a public record. See Klessing, 564 N.W.2d at 716 . And, of course, under Miranda, the privilege against selfincrimination can only be satisfied with a suspect in custody responding to interrogation if that person has been given the standard four warnings. See id.; see also infra notes 296-302 and accompanying text.

169. United States v. Drayton, 536 U.S. 194 (2002) (holding officers conducting search need not tell bus occupants that they may choose not to cooperate).

170. Schneckloth v. Bustamonte, 412 U.S. 218, 227, 231 (1973).

171. Id. The position was reaffirmed in United States $v$. Drayton, 536 U.S. at 194. It is difficult to understand the Court's reference in this case to the "detailed requirements of an 


\section{g. A Pause}

While we recognize the Supreme Court's willingness to defer to law enforcement, we hardly mean to suggest that U.S. courts have been willing to relinquish their watch dog role. Let us now look to the types of cases discussed above in terms of the privacy considerations.

Regarding the drug war jurisprudence, while the Court has certainly accepted the government's requests for broad search authority in many cases, one certainly does not find this in all cases. For instance, in a major setback to the drug war push by federal authorities, the Court recently rebuked efforts to utilize sense enhancing technology to inspect the interior of a house, without prior judicial authorization. ${ }^{172}$ In Kyllo v. United States, the Court struck down the warrantless use of a thermal imaging device on the defendant's house to detect the presence of high intensity lamps commonly used to grow marijuana. ${ }^{173}$ The Court noted:

It would be foolish to contend that the degree of privacy secured to citizens by the Fourth Amendment has been entirely unaffected by the advance of technology. For example, ... the technology enabling human flight has exposed to public view (and hence, we have said, to official observation) uncovered portions of the house and its curtilage that once were private. The question we confront today is what limits there are upon this power of technology to shrink the realm of guaranteed privacy.

The Government maintains, however, that the thermal imaging must be upheld because it detected "only heat radiating from the external surface of the house," ... . The dissent ... contend[s] that there is a fundamental difference between what it calls "off-the-wall" observations and "throughthe-wall surveillance." But just as a thermal imager captures only heat emanating from a house, so also a powerful directional microphone picks up only sound emanating from a house-and a satellite capable of scanning from many miles away would pick up only visible light emanating from a house. We rejected such a mechanical interpretation of the Fourth Amendment in Katz, where the eavesdropping device picked up only sound waves that reached the exterior of the phone booth. Reversing that approach would leave the homeowner at the mercy of advancing technology-including imaging technology that could discern all human activity in the home. While the technology used in the present case was

effective warning." Id. Presumably, in all but the most unusual cases, an adequate warning would entail a speech such as: We would like your permission to search your car/house/bag, but you do not have to give your permission. You can say no and make us get a warrant, and your refusal to give permission cannot be used against you.

172. Kyllo v. United States, 533 U.S. 27 (2001).

173. See id. 
relatively crude, the rule we adopt must take account of more sophisticated systems that are already in use or in development. ${ }^{174}$

Similarly, in terms of the judicial decisions supporting government actions to combat organized crime, it is true that undercover agents have been provided great weapons such as "false friends" questioning as seen in the Hoffa case. ${ }^{175}$ However, the Supreme Court's famous Massiah $v$. United States decision stands as a reminder that there are clear limits on the use of these great weapons. ${ }^{176}$ In Massiah, the police had formally charged the defendant with a crime, but he was no longer in custody, having been released on bail. ${ }^{17}$ The police brought in an undercover agent to befriend the defendant and to elicit incriminating statements from him. ${ }^{178}$ During the course of a lengthy and seemingly friendly conversation between the two, the defendant made the anticipated incriminating statements. ${ }^{179}$ The Court would not allow the statements to be admitted into evidence, holding that the actions of the government violated the defendant's Sixth Amendment right to counsel. ${ }^{180}$ Once that right has attached, the majority wrote, "it must apply to indirect and surreptitious interrogations as well as those conducted in the jailhouse. In this case, Massiah was more seriously imposed upon ... because he did not even know that he was under interrogation by a government agent.","181

The drunk driving roadblocks allowed in the United States demonstrate both the latitude given to the government to deal with a serious societal ill and also the care exercised by U.S. judges when examining privacy claims. That is, the courts allow truly random roadblocks for the purpose of detecting drunk drivers and thus curbing highway carnage, without any individualized suspicion or judicial authorization as they must in order to succeed. ${ }^{182}$ Once the government

174. Id. at 33-36 (internal citations omitted).

175. See Hoffa v. United States, 385 U.S. 293 (1966); see also Illinois v. Perkins, 496 U.S. 292 (1990) (imposing a limitation on the Miranda mandate in the jail cell setting where the defendant is not aware that the cellmate asking questions actually works for the police). In Perkins, however, the police had not yet formally charged the defendant, as they had the defendant in Massiah v. United States. Perkins, 496 U.S. at 496; Massiah v. United States, 377 U.S. 201 (1964).

176. Massiah, 377 U.S. at 201.

177. Id.

178. Id.

179. Id.

180. Id. at 206.

181. Id. (quoting United States v. Massiah, 307 F.2d 62, $72-73$ (N.Y. 1962) (Hays, J., dissenting)).

182. See Michigan Dep't of State Police v. Sitz, 496 U.S. 444, 450-51 (1990). 
strays beyond these boundaries, however, the judicial reception has been chilly. An example of this is Delaware v. Prouse, where officers made stops for the purpose of checking drivers' licenses and automobile registrations. ${ }^{183}$ With no individualized suspicion, and no limits on the officers' ability to make the stops, ${ }^{184}$ the Supreme Court concluded that the actions of the government violated the Fourth Amendment, for citizens are not "shorn of [privacy] interests when they step from the sidewalks into their automobiles."185 The Court reached a similar conclusion in Indianapolis v. Edmond, where the discretion of the officers was narrow, but the goal of the roadblock was not only to check for intoxicated drivers, but also included the seizure of evidence in narcotics crimes. ${ }^{186}$

It is unquestionable that the Supreme Court does not require rigorous Fourth Amendment protections for searches of public school children conducted in an education setting. ${ }^{187}$ As noted earlier, neither warrant nor probable cause is required for searches within schools. ${ }^{188}$ Nevertheless, while American courts have broadly construed the constitutional requirements as to other privacy intrusions in the school

183. Delaware v. Prouse, 440 U.S. 648 (1979).

184. In this case the officers did not select vehicles to stop wholly at random, nor did they conduct a true roadblock where every car or every set number of cars were stopped. Id. at 663 .

185. Id.

186. Indianapolis v. Edmond, 531 U.S. 32 (2000). The Court wrote:

[T]he Indianapolis checkpoint program unquestionably has the primary purpose of interdicting illegal narcotics. In their stipulation of facts, the parties repeatedly refer to the checkpoints as "drug checkpoints" and describe them as "being operated by the City of Indianapolis in an effort to interdict unlawful drugs in Indianapolis."

$\cdots$

We have never approved a checkpoint program whose primary purpose was to detect evidence of ordinary criminal wrongdoing. Rather, our checkpoint cases have recognized only limited exceptions to the general rule that a seizure must be accompanied by some measure of individualized suspicion. We suggested in Prouse that we would not credit the "general interest in crime control" as justification for a regime of suspicionless stops. Consistent with this suggestion, each of the checkpoint programs that we have approved was designed primarily to serve purposes closely related to the problems of policing the border or the necessity of ensuring roadway safety. Because the primary purpose of the Indianapolis narcotics checkpoint program is to uncover evidence of ordinary criminal wrongdoing, the program contravenes the Fourth Amendment.

Id. at 40-42 (internal citations omitted). But see Illinois v. Lidster, 124 S. Ct. 885 (2004) where police set up check point to obtain information about an earlier accident. Distinguishing case from Edmond, the Court allowed the procedure. Id.

187. See discussion infra Part IV.C.2.

188. See New Jersey v. T.L.O. 469 U.S. 325 (1985); supra note 161 and accompanying text. 
environment, ${ }^{189}$ they have never retreated from the view stated earlier: an individualized suspicion must be shown to justify a search for evidence of a crime, and the Fourth Amendment-along with the exclusionary rule-applies to a search of a minor. ${ }^{190}$

The courts have applied the plain view doctrine in an expansive fashion, particularly showing reluctance to impose any sort of inadvertent discovery requirement, as noted above. ${ }^{191}$ Again, however, the U.S. judges have been careful to draw particular lines over which law enforcement cannot cross. One example is the recent case of Bond $v$. United States, in which the government argued for a "plain feel" exception to the Fourth Amendment requirements. ${ }^{192}$ In Bond, a border patrol agent boarded a bus to check the immigration status of its passengers. ${ }^{193}$ After reaching the back of the bus, and deciding that the passengers were lawfully in the United States, the agent began walking toward the front. ${ }^{194}$ Along the way, he squeezed the soft luggage that passengers had placed in the overhead storage space above the seats. ${ }^{195}$ When the agent inspected the luggage in the compartment above Bond's seat, he squeezed a green canvas bag and felt a "brick-like" object. ${ }^{196}$ Bond admitted that the bag was his and consented to the agent opening it. ${ }^{197}$ In the bag, the agent found a "brick" of methamphetamine wrapped in duct tape rolled into a pair of pants. ${ }^{198}$

The government argued that there was no real invasion of privacy because the bus aisle was open to the public, the luggage was in full view of all passengers, and the squeezing of the bag was at most a minimal intrusion. ${ }^{199}$ The majority of the Supreme Court disagreed:

When a bus passenger places a bag in an overhead bin, he expects that other passengers or bus employees may move it for one reason or another. Thus, a bus passenger clearly expects that his bag may be handled. He does not expect that other passengers or bus employees will, as a matter of course, feel the bag in an exploratory manner. But this is exactly what the

189. As in the drug testing of students who participate in after school programs. See Vernonia Sch. Dist. v. Acton, 515 U.S. 646 (1995).

190. See, e.g., M.S. v. Florida, 808 So. 2d 1263, 1264 (Fla. Dist. Ct. App. 2002); People in Interest of P.E.A., 754 P.2d 382, 387 (Colo. 1988).

191. See Arizona v. Hicks, 480 U.S. 321 (1987); Horton v. California, 496 U.S. 128 (1990).

192. Bond v. United States, 529 U.S. 334, 337 (2000).

193. Id. at 335.

194. Id.

195. Id.

196. Id. at 336.

197. Id.

198. Id.

199. Id. at 337. 
agent did here. We therefore hold that the agent's physical manipulation of petitioner's bag violated the Fourth Amendment. ${ }^{200}$

The body of judicial decisions regarding consent to searches and seizures serves as a good illustration of how U.S. courts have gone quite a distance in order to accommodate the desires of law enforcement, while at the same time trying to protect privacy concerns. ${ }^{201}$ Critics of the jurisprudence fault the Supreme Court for allowing consent to stand without evidence that the defendant had been warned of the right to refuse permission to search, or without a showing that the defendant was even aware of this right. ${ }^{202}$ Even these critics, however, note that the Court has emphasized that consent must not result from coercion, and that false police statements about the predicate for the search can serve as the basis for a successful Fourth Amendment challenge. ${ }^{203}$ Moreover, to answer the question of whether consent was voluntary, courts must look to all the surrounding circumstances ${ }^{204}$ to insure that consent was not "the product of official intimidation or harassment [for such agreement] is not consent at all. Citizens do not forfeit their constitutional rights when they are coerced to comply with a request that they would prefer to refuse."205

\section{B. Exclusion of Evidence}

The contrast between the Australian and United States criminal justice systems could not be more pronounced than with respect to remedies for illegal searches conducted by law enforcement officials. Simply stated, Australian judges, as noted above, are reluctant to exercise their discretion to exclude evidence found in such searches. ${ }^{206}$ The evidence rules direct American judges to exclude evidence in a wide

200. Id. at 338-39.

201. Seediscussion infra Part IV.A.2.f

202. See, e.g., Andrew E. Taslitz, A Feminist Fourth Amendment?: Consent, Care, Privacy, and Social Meaning, in Ferguson v. City of Charleston, 9 DUKE J. GENDER L. \& POL'Y 1, 11-13 (2002).

203. Bumper v. North Carolina, 391 U.S. 543, 550 (1968). In this case, the officers advised the home owner that they had a warrant to search the house. Upon hearing this, the owner then consented to the search. Id. at 546-47. In fact, the officers never showed a warrant and the court never entered one into the record. Id. The Supreme Court found that the consent under these particular circumstances was not voluntary, and struck down the resulting search. Id. at 550. "When a prosecutor seeks to rely upon consent to justify the lawfulness of a search, he has the burden of proving that the consent was, in fact, freely and voluntarily given. This burden cannot be discharged by showing no more than acquiescence to a claim of lawful authority." Id. at 548-49 (footnotes omitted).

204. See Ohio v. Robinette, 519 U.S. 33 (1996).

205. Florida v. Bostick, 501 U.S. 429, 438 (1991).

206. See discussion infra Part IV.A.1. 
range of prosecutions; in many situations they have no discretion to admit the unlawfully obtained evidence. ${ }^{207}$

The U.S. exclusionary rule has been highly controversial. It has often been noted that eliminating otherwise reliable evidence from a trial against a culpable defendant is not sensible, for it means that "the criminal [will] go free because the constable has blundered."208 Moreover, many have argued that if the point of exclusion is to modify the actions of officers and deter them from engaging in improper behavior, other less onerous methods could achieve that end. Suggestions have been made to more broadly utilize civilian review boards, ${ }^{209}$ to allow for civil actions against the police, ${ }^{210}$ and to promote employment sanctions against offending officers. ${ }^{21}$

Having acknowledged these views, ${ }^{212}$ nevertheless, the United States Supreme Court established its rule of exclusion in virtually all search and seizure cases, both state and federal, more than four decades ago in

207. See discussion infra Part IV.A.2.

208. As stated first by then Judge Benjamin Cardozo in People v. Defore, 150 N.E. 585, 587 (N.Y. 1926). For broad based critiques of the exclusionary rule, see Guido Calabresi, The Exclusionary Rule, 26 HARV. J.L. \& PUB. POL'Y 111, 111-18 (2003); Christopher Slobogin, Why Liberals Should Chuck the Exclusionary Rule, 1999 U. ILL. L. REv. 363, 363-446; Gregory D. Totten et al., The Exclusionary Rule: Fix It, But Fix It Right, 26 PEPP. L. REv. 887, 887-922 (1999); William J. Stunt, The Virtues and Vices of the Exclusionary Rule, 20 HARV. J.L. \& PUB. POL'Y 443, 445-55 (1997); Lawrence Crocker, Can the Exclusionary Rule be Saved?, 84 J. CRIM. L. \& CRIMINology 310, 310-51 (1993); Pierre J. Schlag, Assaults on the Exclusionary Rule: Good Faith Limitations and Damage Remedies, 73 J. CRIM. L. \& CRIMINOLOGY 875, 875-915 (1982). But see Yale Kamisar, In Defense of the Search and Seizure Exclusionary Rule, 26 HaRv. J.L. \& PUB. POL'Y 119, 119-40 (2003); Timothy Lynch, In Defense of the Exclusionary Rule, 23 HaRV. J.L. \& PuB. Pol'y 711, 751 (2002).

209. See, e.g., Sean Hecker, Race and Pretextual Traffic Stops: An Expanded Role for Civilian Review Boards, 28 ColuM. HuM. RTS. L. REv. 551, 551-604 (1997); Reenah Kim, Legitimizing Community Consent to Local Policing: The Need for Democratically Negotiated Community Representation on Civilian Advisory Councils, 36 HARV. C.R.-C.L. L. REV. 461, 461525 (2001). The suggestion remains controversial. See Christopher Dunn \& Donna Lieberman, A Review Board in Name Only, N.Y. Times, July 19, 2003, at A13.

210. See Bivens v. Six Unknown Named Agents of Fed. Bureau of Narcotics, 403 U.S. 388, 422-24 (1971) (Burger, C.J., dissenting). Chief Justice Burger argued for allowing suits against the government in a special tribunal trained to look at evidentiary concerns. Id. at 423 . Under his view, the abolition of the exclusionary rule could follow the establishment of such tribunals. Id. at 422-23. For an interesting alternative plan, see Donald Dripps, The Case for the Contingent Exclusionary Rule, 38 AM. CRIM. L. REV. 1, 2-4 (2001).

211. See Roger L. Goldman \& Steven Puro, Revocation of Police Officer Certification: $A$ Viable Remedy for Police Misconduct?, 45 ST. LouIS U. L.J. 541, $541-45$ (2001); Laurie L. Levenson, Administrative Replacements: How Much Can They Do?, 26 PEPP. L. REV. 879, 87986 (1999).

212. For a viewpoint which recognizes these views, yet charges that utilizing exclusion as a general remedy greatly, and negatively, affects the reach given to the substantive content of the Fourth Amendment, see Slobogin, supra note 208, at 363-446. 
Mapp v. Ohio. ${ }^{213}$ This law established in 1961, is still vibrant today and remains virtually unchallenged. ${ }^{214}$ Stated simply, if the police action to obtain the evidence against the defendant violates the Constitution, a court will generally deem such evidence inadmissible at trial. ${ }^{215}$ In Mapp, the police acted in a blatantly illegal fashion, yet Ohio determined that the defendant did not have a viable remedy. ${ }^{216}$ Other states, however, and the federal system, had for many years utilized an exclusionary rule to deal with such situations. ${ }^{217}$ The United States Supreme Court made clear that it would not tolerate any other alternatives in situations where Fourth Amendment violations could be proven. ${ }^{218}$

The ignoble shortcut to conviction left open to the State tends to destroy the entire system of constitutional restraints on which the liberties of the people rest. Having once recognized that the right to privacy embodied in the Fourth Amendment is enforceable against the States, and that the right to be secure against rude invasions of privacy by state officers is, therefore, constitutional in origin, we can no longer permit that right to remain an empty promise.... [W] can no longer permit it to be revocable at the whim of any police officer who, in the name of law enforcement itself, chooses to suspend its enjoyment. ${ }^{219}$

213. See Mapp v. Ohio, 367 U.S. 643 (1961).

214. While most famous, perhaps, for its restriction of evidence in search and seizure cases, courts use the exclusionary rule in other ways. Another common use is the exclusion of confessions. Even those statements found to be absolutely accurate will be kept out of evidence if the statements:

1. were involuntarily made, under the Due Process Clause. See Spano v. New York, 360 U.S. 315 (1959);

2. were obtained without warnings being given, against the mandate of the privilege against self incrimination. See Miranda v. Arizona, 384 U.S. 436 (1966);

3. resulted from a violation of the Sixth Amendment, with questioning occurring after the formal charge and without the assistance of counsel. See Brewer v. Williams, 430 U.S. 387 (1977).

215. Mapp, 367 U.S. at 660.

216. Police officers pretended to have a search warrant, yet never produced one. Id. The Court even noted that "[a]t best "there is, in the record, considerable doubt as to whether there ever was any warrant." Id. at 645 (internal citations omitted). The police officers forcibly entered the defendant's home after she refused to give consent to a search. Id. After "[r]unning roughshod over appellant, a policeman 'grabbed' her, 'twisted [her] hand," and took her upstairs in handcuffs. Id. (internal citations omitted). Ultimately the police found obscene materials and charged her with possession. Id.

217. The federal exclusionary rule had been established in Weeks v. United States. By 1961 quite a number of states utilized such a rule as well. See Weeks v. United States, 232 U.S. 383 (1914); Mapp v. Ohio, 367 U.S. 643 (1961) (overruling Weeks).

218. "There is no war between the Constitution and common sense... Nothing can destroy a government more quickly than its failure to observe its own laws." Mapp, 367 U.S. at 657,659 . This protection extended to other constitutional violations as well. See supra note 214 and accompanying text.

219. Mapp, 367 U.S. at 660. 
While the exclusionary rule remains the law in the United States, changes have occurred in its application. ${ }^{220}$ The initial justifications for the rule were to deter improper police conduct, and to protect judicial integrity in terms of evidence offered at trial. ${ }^{221}$ These dual reasons have given way to a single rationale for the rule, deterrence of improper police activity. ${ }^{222}$ As a consequence, significant limitations on the exclusionary rule have developed. Perhaps the most famous is the principle that a court will not grant an exclusion in situations where the police act in good faith to obtain a warrant which later turns out to have been improperly granted. ${ }^{223}$ In addition, evidence will only be excluded if police action violated a defendant's own privacy right, ${ }^{224}$ illegal action taints the evidence ${ }^{225}$ and the prosecution uses that evidence to prove the defendant's guilt. ${ }^{226}$ Finally, the rule only applies if evidence is actually found. ${ }^{227}$ That is, capturing the defendant and bringing her improperly into the jurisdiction will not give rise to a claim under the rule..$^{228}$

Some have argued that these limitations have effectively nullified the power of the exclusionary rule. ${ }^{229}$ The rule, however, remains viable and courts use it in a wide range of fact situations. For instance, in recent

220. See infra notes 223-228 and accompanying text.

221. "Our decision, founded on reason and truth, gives ... to the courts, that judicial integrity so necessary in the true administration of justice." Mapp, 367 U.S. at 660.

222. See United States v. Leon, 468 U.S. 897, 926 (1984). For a sharp critique of this shift see generally, Yale Kamisar, Does (Did) (Should) the Exclusionary Rule Rest on a "Principled" Basis" Rather Than an "Empinical Proposition"?, 16 CREIGHTON L. REV. 565 (1982).

223. See Leon, 468 U.S. at 924-26. States are, of course, entitled to offer criminal defendants more protection than given under the federal Constitution. Several states have rejected the good faith exception set out by the Court in Leon. See, e.g., State v. Marsala, 579 A.2d 58, 60 (Conn. 1990); State v. Carter, 370 S.E.2d 553, 557 (N.C. 1988); State v. Novembrino, 519 A.2d 820, 825 (N.J. 1987).

224. In order to have standing, each defendant must show that police action invaded a sufficient privacy interest of their own. Minnesota v. Carter, 525 U.S. 83, 89 (1998). It is not enough to show that the prosecution offered the evidence-obtained illegally as to another person-against him at trial. Id.

225. The Fruit of the Poisonous Tree principle indicates that not all resulting evidence will be excluded, only that evidence which is not remote and too far removed. See Wong Sun v. United States, 371 U.S. 471 (1963). The Court gives the doctrine an especially broad application in regard to live witnesses who will testify at trial. See United States v. Ceccolini, 435 U.S. 268, 275 (1978). Also, the government will be relieved of the exclusion burden if it can demonstrate that the tainted evidence would have been discovered "inevitably" through lawful means. See Nix v. Williams, 467 U.S. 431, 444 (1984).

226. As opposed to the prosecution offering the evidence to impeach the defendant's testimony at trial. The impeachment limitation can arise in connection with tangible evidence obtained through police searches. See Walder v. United States, 347 U.S. 62, 65 (1954). It can also pertain to statements from interrogation. See Harris v. New York, 401 U.S. 222, 232 (1971).

227. See Frisbie v. Collins, 342 U.S. 519, 522 (1952).

228. Id.

229. Leon, 468 U.S. at 928-29 (Brennan, J., dissenting). 
years, the Supreme Court has not hesitated to exclude evidence in cases involving anonymous tips ${ }^{230}$ the pat down of luggage, ${ }^{231}$ road blocks, ${ }^{232}$ improper frisking of individuals who have been lawfully detained, ${ }^{233}$ and the taking of a statement after an illegal arrest. ${ }^{234}$

\section{Rules of Interrogation \\ 1. In Australia}

Traditionally, common law rules governing the interrogation of suspects in Australia have developed to

1. ensure the reliability of confessional evidence, and

2. to maintain an accused's right to silence. ${ }^{235}$

Judicial rhetoric is to the effect that interrogation rules are not designed to directly regulate police misconduct. ${ }^{236}$ Rather, the court focuses on the effect that any police misconduct may have on the reliability of the confession extracted, and whether, as a result of the misconduct, the accused has been actually or effectively deprived of the right to speak freely. ${ }^{237}$

Nonetheless, it is generally only where interrogating authorities have behaved improperly that the courts will exclude confessional evidence. ${ }^{238}$ Usually, the authorities must demonstrate some form of external pressure over and above ordinary interrogation techniques to justify excluding a confession. ${ }^{239}$ Consequently, unless categorized as persons of special vulnerability, ${ }^{240}$ the courts expect those suspected of crimes to conduct themselves robustly during interrogation. ${ }^{241}$ Australian courts have admitted confessions where:

230. Florida v. J.L., 529 U.S. $266(2000)$.

231. Bond 529 U.S. at 334-35.

232. See Indianapolis v. Edmond, 531 U.S. 32, 44 (2000).

233. See Minnesota v. Dickerson, 508 U.S. 366, 378 (1993).

234. See Kaupp v. Texas, $123 \mathrm{~S}$. Ct. 1843, 1847 (2003) (applying the rule despite the fact that Miranda warnings had been given).

235. The King v. Lee (1950) 82 C.L.R. 133, 153; McDermott v. R. (1948) 76 C.L.R. 501, 511.

236. Question of Law Reserved [No 1] (1998) 70 S.A. St. R. 281, 288 (per Doyle, C.J.); R. v. Azar (1991) 56 A. Crim. R. 414, 418 (per Gleeson, C.J.); Collins v. R. (1980) 31 A.L.R. 257.

237. See Pavic v. The Queen (1998) 192 C.L.R. 159.

238. See infra notes 245-247.

239. See, e.g., Pfitzner v. R. (1996) 66 S.A. St. R. 161, 173 (per Doyle, C.J.).

240. See, e.g., M v. A.J. (1989) 44 A. Crim. R. 373, 381 (referring to children); Collins, 31 A.L.R. 257 (referring to Aborigines); Dixon v. McCarthy (1975) 1 N.S.W.L.R. 617.

241. JiLl HuNTER \& KATHRYN CRONIN, EVIDENCE, ADVOCACY AND ETHICAL PRACTICE: A CRIMINAL TRIAL COMMENTARY 454 (1995). 
1. the suspect experienced psychotic episodes during questioning: ${ }^{242}$

2. the suspect was very drunk; ${ }^{243}$ and

3. the suspect was under the influence of drugs. ${ }^{24}$

On the other hand, the courts have excluded confessions where:

1. the police failed to properly caution the suspect prior to interrogation, ${ }^{245}$

2. the police held the suspect illegally for the purpose of interrogation, ${ }^{246}$ and

3. the police importuned admissions by offering benefits such as reduced sentence, bail, or witness protection. ${ }^{247}$

\section{a. Voluntariness}

As noted above, at common law a confession must be voluntary to be admissible. A confession is involuntary if the police obtain it by overbearing the will of an accused due to violence, threats of violence, or inducements. ${ }^{248}$

While section 84 of the Australian Evidence Act is not cast in terms of voluntariness, it operates in a broadly similar fashion. ${ }^{249}$ In New South Wales, Tasmania, and the Australian Capital Territory, courts must exclude admissions if they were influenced by violence, the threat of violence, oppressive, inhuman, or degrading conduct. ${ }^{250}$ Unlike the common law, however, there is no need to establish a causative link

242. Sinclair v. the King (1946) 73 C.L.R. 316, 328; R. v. Pfitzner (1996) 66 S.A. St. R. 161; R. v. Starecki (1960) V.R. 141, 151; see also R. v. Munce (2001) N.S.W.S.C. 1072 q 13. In Munce, the accused was under the influence of alcohol and drugs, and also suffered psychiatric problems. Id. at $1072 \uparrow 27$. The court found that the authorities most likely did not compromise the truth of the confession. Id. The court found this because the accused voluntarily went to the police station and because the interrogation was scrupulously fair. Id. Nor did the court find that the circumstances rendered it unfair to use the confession against the accused. Id.

243. The Queen v. Ostojic (1978) 18 S.A. St. R. 188, 197; R. v. Ainsworth (1991) 57 A. Crim. R. 174, 179. Contra R. v. Smith (1992) 58 S.A. St. R. 491, 495-97.

244. See Munce, N.S.W.S.C. at 1072; Regina v. Frawley (2000) N.S.W. Ct. Crim. App. 340

I 33; R. v. Reinders \& Widdison (1993) N.T. Sup. Ct. 73; R. v. Ella (1990) 100 F.L.R. 442.

245. R. v. Dolan (1992) 58 S.A. S.R. 501, 501; Walker v. Viney (1965) T. R. 96, 97.

246. Foster v. The Queen (1993) 67 A.L.J.R. 550, 557.

247. R. v. Ye Zhang (2000) N.S.W.S.C. 1099, १ा 40-41.

248. R. v. Lee (1950) 82 C.L.R. 133; McDermott v. R. (1948) 76 C.L.R. 501; Cornelius v. R. (1936) 55 C.L.R. 235, 245.

249. Evidence Act, 1995, $\S 84$ (Austl.).

250. See generally id. The Communication Act has been adopted in all three territories. 
between the violence or oppressive conduct and the making of an admission. ${ }^{251}$

Section 85 renders an admission inadmissible if it is likely that any relevant condition or characteristic of the accused adversely affected the truth of the admission. ${ }^{252}$ Section 85 only applies during questioning by investigating authorities, ${ }^{253}$ whereas section 84 applies if violence, threat of violence, or oppression occurs under any circumstance. ${ }^{254}$

\section{b. Exclusion}

The majority of the High Court in Pavic $v$. The Queen, attempted to reformulate the common law position in relation to discretionary exclusion. ${ }^{255}$ Under that reformulation, Australian courts applying the common law have discretion to exclude evidence of confessions:

1. where the confession is unreliable; ${ }^{256}$ or

2. where, in all the circumstances including unfairness to the defendant and the impropriety of investigating officials, the confession was obtained contrary to community standards. ${ }^{257}$

The facts of Pavic $v$. The Queen illustrate the distinction between unreliability and unfairness/impropriety. ${ }^{258}$ Swaffield refused to answer questions concerning his involvement in an arson during a formal police interview. $^{259}$ Subsequently, however, he made admissions to an undercover police officer investigating drug offenses. ${ }^{260}$ The officer recorded the admissions without Swaffield's knowledge, and without Swaffield receiving any warning concerning his right to silence. ${ }^{261}$ There

251. See id.

252. Relevant conditions or characteristics include age, personality, education, or mental, physical, or intellectual disability. Id. $\S 85$.

253. Hence, section 85 of the Evidence Act, would not apply to the confession obtained in Pavic v. The Queen. Pavic v. The Queen (1998) 192 C.L.R. 159, 165; see also R. v. Truong (1996) 86 A. Crim. R. 188, 193; R. v. Donnelly (1997) 96 A. Crim. R. 432, 437 (discussing admissibility of admissions by defendants).

254. Evidence Act, $1995 \S 84$ (Austl.).

255. Pavic, 192 C.L.R. at 194 (per Gaudron, J., Toohey, J., \& Gummow, J.J.).

256. Id.

257. Id. Community standards in this context means the standards required to maintain the rule of law in a liberal democracy, to ensure the proper administration of justice and to ensure the due requirements of law enforcement. R. v. Suckling (1999) N.S.W. Ct. Crim. App. 36, 40. But see criticisms of Brad Selway, Principle, Public Policy and Unfairness-Exclusion of Evidence on Discretionary Grounds, 23 ADEL. L. REV. 1, 26 (2002) (raising "the danger of using 'the community' as part of a quasi-factual test which can never be analysed or tested")

258. Pavic, 192 C.L.R. at $168-80$.

259. Id. at 165.

260. Id. at 165-66.

261. Id. 
was nothing to suggest that Swaffield's admissions were untrue. ${ }^{262}$ Nonetheless, the High Court determined that obtaining admissions from Swaffield surreptitiously, following his decision not to speak to the police, was unfair and improper. ${ }^{263}$ The Court held that the police obtained the admissions at "an unacceptable price" and excluded them. ${ }^{264}$

Although the High Court decided Foster v. R. prior to Pavic, it is a good example of a combination of unfairness and police impropriety leading to the exclusion of a confession. ${ }^{265}$ Foster was a twenty-one-yearold Aboriginal man with little education, who the police charged with arson. ${ }^{266}$ The police who arrested Foster admitted their motive for the arrest was to pressure him into making a confession. ${ }^{267}$ The manner of arrest was very high-handed, removing Foster from a family gathering, placing him in the caged section of a police van, and driving him some distance away to the isolation of a police cell. ${ }^{268}$

When arrested Foster had asked if he could bring a friend with him. ${ }^{269}$ Foster claimed that the police denied this request. ${ }^{270}$ According to Foster, the confession was a fabrication and the police extracted his signature on the typed document by threats of violence against him and his brother. ${ }^{271}$

Even putting aside Foster's claims regarding the fabricated confession and threats of violence, the high-handed nature of his arrest made it clear to him that he was completely powerless in the face of police authority. ${ }^{272}$ There exists a possibility that Foster may have confessed merely to be released from custody. Subsequently, the High Court determined that the confession should have been excluded on the basis of unfairness and impropriety. ${ }^{273}$ The unfairness to Foster arose because he could not corroborate his version of the events leading up to the confession, and was therefore put at a forensic disadvantage when he challenged the confession at trial. ${ }^{274}$ The court also held that the police

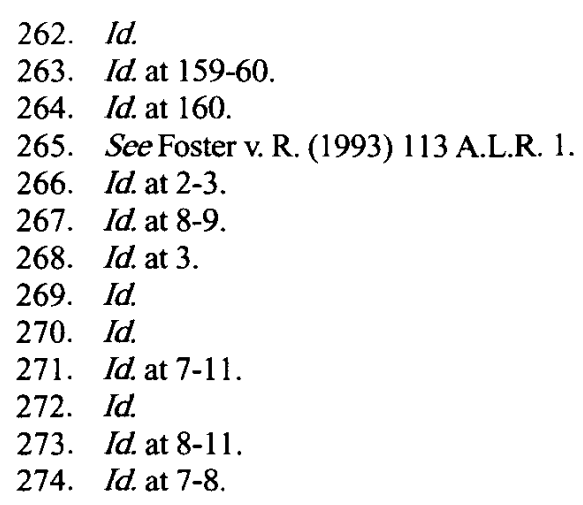


improperly obtained the confession because the police deliberately abused their powers of arrest and detention. ${ }^{275}$

When reformulating the common law approach to discretionary exclusion, the majority of the High Court in Pavic did so on the basis that they were taking into account the provisions of Australia's Evidence Act of $1995 .^{276}$ However, it is not immediately evident from the structure of the Evidence Act, how this might be so. Section 85 of the Evidence Act renders unreliable confessions obtained during the course of police questioning inadmissible. ${ }^{277}$ If a confession obtained in this manner is likely to be untrue the court must exclude it. ${ }^{278}$ Similarly, evidence adduced by the prosecution that is unfairly prejudicial to an accused in criminal proceedings must be excluded under section $137 .{ }^{279}$ Section 90 creates a specific discretion to exclude confessions for unfairness. ${ }^{280}$ It is not limited to confessions obtained during the course of official questioning. ${ }^{281}$ In addition, section 138 allows evidence to be excluded, whether confessional or not, where the police improperly or illegally obtain it. ${ }^{282}$ An approach consistent with Pavic would require that section 90 be confined to situations that affect the reliability of confessional evidence, and section 138 to be read so as to combine both impropriety and unfairness. ${ }^{283}$ While there is some lower level case law supporting this approach, ${ }^{284}$ others have opined that, following Pavic, principles governing discretionary exclusion in common law and Australia's Evidence Act of 1995 jurisdictions are divergent. ${ }^{285}$

275. Id. at 8-11.

276. Pavic, 192 C.L.R. at 194 (considering Evidence Act, 1995 (Austl.)).

277. Evidence Act, 1995, $\S 85$ (Austl.).

278. Id.

279. Id. $\S 137$.

280. Id. $\$ 90$.

281. Id.

282. Id. $\S 138$. The discretion under section 138 is cast differently from the common law discretion. Under the common law, evidence illegally obtained is admissible, subject to a discretion to exclude it. Under section 138, evidence illegally obtained is inadmissible, subject to the discretion to allow its admission if the desirability of admitting the evidence outweighs the undesirability of admitting the evidence.

283. Pavic, 192 C.L.R. at 194 (interpreting Evidence Act, 1995, §§ 90, 138 (Austl.)).

284. E.g., R. v. Taylor (1999) Austl. Cap. Terr. Ct. 34, 47; R. v. Munce (2001) N.S.W.S.C. 1072, 36-37; R. v. Suckling (1999) N.S.W. Ct. Crim. App. 36, 40-43; R. v. Helmhout (2001) N.S.W. Ct. Cr. App. 251, 259.

285. E.g., Selway, supra note 257, at 25 (citing R. v. Sotheren (2001) N.S.W.S.C. 204, 241 47); R. v. Smith (2000) N.S.W. Ct. Crim. App. 202; R. v. Walker (2000) N.S.W. Ct. Crim. App. 130; R. v. Douglas (2000) N.S.W. Ct. Crim. App. 275). 


\section{In the United States}

As seen above, one can quickly identify three key features present in the Australian criminal justice system relating to the interrogation process. The first is the use of the voluntariness standard as the linchpin of analysis to determine the propriety of actions by law enforcement officers that result in admissions made by criminal suspects. The second is the considerable discretion given to trial judges to determine the validity of particular incriminating statements, in ruling on the admissibility of improperly made statements. The third is that much of the law in this area has not developed as a way to have judicial oversight or supervision of potential police misconduct.

The American criminal justice system has moved away from these views in terms of deciding whether incriminating statements are admissible at trial to prove the guilt of criminal defendants. On each of these three features U.S. courts have taken a distinctly contrary view.

While the voluntariness standard remains viable ${ }^{286}$ the United States Supreme Court's concerns about the limited precedential value of court decisions in the area, along with the broad and not easily definable standard itself, led the Court to adopt far more specific and identifiable standards than those provided by the voluntariness test. ${ }^{287}$ The Court's initial move was to look to the right to counsel, found in the Sixth Amendment of the Constitution. ${ }^{288}$ Finding that this right meant that a defendant could not be questioned ${ }^{289}$ by a police agent without the presence of a lawyer, ${ }^{290}$ the Court held that any resulting incriminating statement by the accused, made without counsel, could not be admitted into evidence. ${ }^{291}$

286. See, e.g., Trice v. Ward, 196 F.3d 1151, 1170 (10th Cir. 1999). The court there explained that the analysis is to view a "totality of circumstances" including:

"[T]he crucial element of police coercion," "the length of the interrogation" and "its continuity," "the defendant's maturity," "education," "physical condition," and "mental health," and "the failure of the police to advise the defendant of his rights to remain silent and to have counsel present during the custodial interrogation." Ultimately, the question is whether the confession was "the product of an essentially free and unconstrained choice."

Id. at 1170 (internal citations omitted).

287. For a sharp critique of the U.S. system, in comparison to the Australian, see Michael R. McCoy, Is There a Need for Miranda: A Look at Australian and Canadian Interrogation, 7 ARIZ. J. INT'L \& COMP. L. 627, 638-49 (2000).

288. See Massiah v. United States, 377 U.S. 201, 206 (1964); U.S. CoNST. amend. VI.

289. This applies even when a defendant does not realize he is being questioned, as with the involvement of an undercover officer. Massiah, 377 U.S. at 206.

290. The defendant can waive this right, but the standard is high. See Brewer v. Williams, 430 U.S. 387,404 (1977)

291. Id. at 404-05 
The Sixth Amendment clearly defines a standard. ${ }^{292}$ It is, however, limited in scope, for the rule only applies if the government has formally charged the defendant. ${ }^{293}$ As a consequence, the standard applies to relatively few interrogations since most occur after arrest, but prior to any formal charge. ${ }^{294}$ Therefore, it is the Fifth Amendment standard, as enunciated in the famous Miranda v. Arizona decision, which has had the greater impact on the criminal justice system. ${ }^{295}$

In Miranda, the Supreme Court held that if the police interrogate an accused while in custody, any resulting incriminating statements may only be used at trial to prove her guilt if the police gave the defendant four specific warnings, after which she affirmatively waived her right to avoid the interrogation. ${ }^{296}$ Under the Fifth Amendment privilege against self-incrimination the suspect must be informed:

1. Of the right to remain silent;

2. That any statement made can be used against her at trial;

3. Of the right to have an attorney present during questioning; and

4. That the government will provide a lawyer if she is unable to afford one on her own. ${ }^{297}$

This fairly concrete standard has not eliminated all uncertain issues. ${ }^{298}$ Still, there is little doubt that, as the Supreme Court has stated, it provides much greater guidance to all parties, as "[the voluntariness test] is more difficult than Miranda for law enforcement officers to conform to, and for courts to apply in a consistent manner."299

Under both the Fifth and Sixth Amendment standards set forth, if a violation occurs the trial court has no discretion as to which remedy to

292. U.S. CONST. amend. VI.

293. The Sixth Amendment provides that the right to counsel shall be present "in all criminal prosecutions." U.S. CONST. amend. VI. That phrase has been construed to mean the stage at which a formal charge, not simply an arrest, has taken place. See Kirby v. Illinois, 406 U.S. 682, 690 (1972). Commonly, that includes indictments issued by grand juries, and preliminary hearings conducted by judges. See id. at 688-89.

294. See id.

295. Miranda v. Arizona, 384 U.S. 436 (1966); U.S. ConST. amend. V.

296. Miranda, 384 U.S. at 478-79.

297. The Fifth Amendment provides that "No person ... shall be compelled in any criminal case to be a witness against himself." U.S. CoNST. amend. V; see also Miranda, 384 U.S. at 471 .

298. Much litigation has been centered on defining terms such as "custody" and "interrogation." See Paul Marcus, Criminal Procedure in Practice ch. 4 (2d ed. 2003). Also, there has been some confusion regarding the evidence necessary to demonstrate a willing waiver. Id. Plus, cases have grappled with whether exceptions to the rule are allowed (two are most noteworthy: for public safety and the use of confessions to impeach). Id.

299. Dickerson v. United States, 530 U.S. 428, 444 (2000) (internal citations omitted). 
use; it must exclude the resulting incriminating words. ${ }^{300}$ Moreover, much of the rationale for this holding is in sharp contrast to Australian decisions. That is, Americans believe there is a need for courts to intervene here in order to curb excessive law enforcement behavior which could adversely impact an affirmative constitutional right. ${ }^{301}$ See, for instance, this language from Miranda:

[C]oercion can be mental as well as physical, and ... the blood of the accused is not the only hallmark of an unconstitutional inquisition. Interrogation still takes place in privacy.... The police [may] persuade, trick, or cajole [the defendant] out of exercising his constitutional rights.

Even without employing brutality, [or] the "third degree" ... the very fact of custodial interrogation exacts a heavy toll on individual liberty and trades on the weakness of individuals. ${ }^{302}$

\section{The Right to Legal Representation}

It certainly should be no surprise that adversarial criminal justice systems, such as Australia and the United States, view the right to counsel as essential. After all, lawyers represent the government throughout the criminal process and the defendant is entitled to offer a defense and to rebut the prosecution's case. For over seventy years, American courts have consistently acknowledged the need for lawyers to represent criminal defendants throughout the process. In one of the most celebrated opinions in the area, the so-called "Scottsboro case,", the United States Supreme Court emphasized this point:

The right to be heard would be, in many cases, of little avail if it did not comprehend the right to be heard by counsel. Even the intelligent and educated layman has small and sometimes no skill in the science of law. If charged with crime, he is incapable, generally, of determining for himself whether the indictment is good or bad. He is unfamiliar with the rules of evidence. Left without the aid of counsel he may be put on trial without a proper charge, and convicted upon incompetent evidence, or evidence irrelevant to the issue or otherwise inadmissible. He lacks both the skill and knowledge adequately to prepare his defense, even though he have a

300. This principle is also true under the voluntariness standard. The judge must exclude a statement which he finds to be coerced. See Lynumn v. Illinois, 372 U.S. 528, 529-38 (1963).

301. See Miranda, 384 U.S. at 455.

302. Id. at 448, 455 (internal citations omitted).

303. Powell v. Alabama, 287 U.S. 45 (1932). Several black youths were charged with raping two white girls on a train. Id. at 49. The defendants were brought to Scottsboro, Alabama, and were tried while confronting a "tense, hostile, and excited public sentiment." $I d$. at 51 . The case deeply disturbed the Justices, and they reversed the convictions because the defendants were young, poor, and illiterate nonresidents who were convicted without attorneys to represent them. Id. at $72-73$. 
perfect one. He requires the guiding hand of counsel at every step in the proceedings against him. Without it, though he be not guilty, he faces the danger of conviction because he does not know how to establish his innocence. $^{304}$

In Gideon v. Wainwright, the Court established the right to counsel for indigent defendants under the Sixth Amendment to the Constitution. ${ }^{305}$ While the Court, here, was more succinct than in Powell, it was just as forceful. ${ }^{306}$ The Court noted, "[I]n our adversary system of criminal justice, any person haled into court, who is too poor to hire a lawyer, cannot be assured a fair trial unless counsel is provided for him.,"30

American judges have extended this right broadly to include virtually every stage of the criminal proceeding, such as post-charge interrogation $^{308}$ and identification procedures, ${ }^{309}$ preliminary hearings, ${ }^{310}$ sentencing, ${ }^{311}$ and appeals. ${ }^{312}$ The right to counsel applies in almost all criminal cases except for the most trivial. ${ }^{313}$ In addition, the indigent defendant may also have the right to other professional assistance such as

304. Id. at 68-69.

305. Gideon v. Wainwright, 372 U.S. 335, 344 (1963).

306. Id

307. Id.

308. See Massiah v. United States, 377 U.S. 201 (1964). The right to a lawyer would not extend, under the Sixth Amendment, to interrogation which occurred prior to the police formally charging the defendant. See supra notes 175-177. However, under Miranda, the Fifth Amendment mandates that the accused, if in custody and being interrogated, must be informed of the right to have a lawyer present during interrogation. Miranda, 384 U.S. at 479.

309. See United States v. Wade, 388 U.S. 218, 223-27 (1967); Kirby v. Illinois, 406 U.S. 682 (1972) (holding the right to a lawyer would not extend to an identification which occurred prior to the defendant being formally charged).

310. See Coleman v. Alabama, 399 U.S. 1, 3-20 (1970); see also United States v. Mandujano, 425 U.S. 564, 574-75 (1976) (holding the right to a lawyer would not extend to a grand jury proceeding, as it is viewed as investigative rather than accusatory).

311. See Mempa v. Rhay, 389 U.S. 128 (1967).

312. Almost every American criminal defendant is entitled to at least one automatic appeal. See Ross v. Moffitt, 417 U.S. 600, 609 (1974). Thereafter, the reviewing court has discretion over the appeals. Id. at 611 . If the appeal is automatic, the grant of counsel is also automatic. Id. at 618-19. If the appeal is discretionary, so is the grant of counsel. Id:; see also infra notes 334-335 and accompanying text.

313. The trial court makes this determination before the trial in terms of what the likely sentence will be. That is, the trial court may not constitutionally sentence the defendant to any term of imprisonment, even the most limited, unless it offered the defendant assistance of counsel. See Scott v. Illinois, 440 U.S. 367, 373-74 (1979). The Supreme Court recently extended the constitutional rule so that counsel must be provided to indigent defendants facing a suspended jail term. See Alabama v. Shelton, 535 U.S. 654, 660-74 (2002). Of course, states are free to go beyond the Court's holdings, and many do, mandating counsel in all criminal cases. See, e.g., Tracy v. Mun. Court for the Glendale Judicial Dist. of L.A. County, 587 P.2d 227, 230 (Cal. 1978) 
medical or technical experts. ${ }^{314}$ The system hardly works to perfection, and has been subject to rather blistering criticism, particularly regarding the effective assistance of counsel. ${ }^{315}$ Still, it is a system which spends considerable sums of money to ensure the representation for almost all criminal defendants in the United States at almost all critical stages of the case. ${ }^{316}$

In Australia, statutes supply the right to legal representation in all jurisdictions. ${ }^{317}$ However, this statutory right only exists as a right to retain legal counsel, not a right to legal counsel per se. ${ }^{318}$ Consequently, legal representation was, up until the High Court's decision in Dietrich v. The Queen, ${ }^{319}$ the prerogative of the rich or those lucky enough to qualify for legal aid. ${ }^{320}$ To remedy that disadvantage, the High Court determined that the inherent power of the courts to ensure the integrity of their own proceedings includes, within it, the capacity and responsibility to ensure a fair trial. ${ }^{321}$ Accordingly, where the requirement of a fair trial demands that the accused have legal representation, the court may grant a stay of proceedings if the accused cannot afford legal representation. ${ }^{322}$ In discussing this common law discretion, a member of the High Court commented:

An accused is brought involuntarily to the field in which he is required to answer a charge of serious crime. Against him, the prosecution has available all the resources of government. If an ordinary accused lacks

314. Ake v. Oklahoma, 470 U.S. 68, 83 (1985) (explaining that such expert aid is required if necessary for a fair trial).

315. See Alfredo Garcia, The Right to Counsel Under Siege: Requiem for an Endangered Right?, 29 AM. CRIM. L. REv. 35, $81-85$ (1991); William S. Geimer, A Decade of Strickland's Tin Horn: Doctrinal and Practical Undermining of the Right to Counsel, 4 WM. \& MARY BLL RTS. J. 91, 111-14 (1995); McNulty \& O'Fahey, Annual Review of Criminal Procedure: Right to Counsel, 88 GEO. L.J. 1317, 1329-34 (2000).

316. The cost is truly enormous. In 1999 the government spent an estimated $\$ 1.2$ billion to provide counsel to indigent defendants in just 100 of the nation's most populous counties. U.S. DEP'T OF JUSTICE, INDIGENT DEFENSE STATISTICS 1 (1999), at http://www.ojp.usdoj.gov/bjs/id.htm (last visited Oct. 14, 2003).

317. Judiciary Act, 1903, $§ 78$ (Austl.); Crimes Act, 1900, $\$ 402$ (N.S.W.) (as applied in Austl. Cap. Terr.); Criminal Procedure Act, 1986, $\S 96$ (N.S.W.); Criminal Code, $\S 360$ (N. Terr. Austl.); Criminal Code, $\S 616$ (Queensl.); Criminal Code Act, $\S 368$ (Tas.); Crimes Act, 1958, $\S 397$ (Vict.); Criminal Code, $\S 634$ (W. Austl.).

318. Greg Reinhardt, Legal Representation at Trial: Scope of the Right, in THE LAWs of AUSTRALIA 11.9 \6 (ii) (1999).

319. Dietrich v. The Queen (1992) 177 C.L.R. 292.

320. The provision of legal services pursuant to a national scheme administered by state and territory governments on a discretionary basis is subject to means and assets tests. See also Don Fleming \& Amanda Pearce, Legal Aid, in Laws OF Australla, supra note 318, ch. 11.9 ๆ 38.

321. Dietrich, 177 C.L.R. at 299-300.

322. Id. at 311. 
the means to secure legal representation for himself, ... he will, almost inevitably, be brought to face a trial process for which he will be ... unable effectively to cope. In such a case, the adversarial process is unbalanced and inappropriate and the likelihood is that ... the forms and formalities of legal procedures will conceal the substance of oppression. ${ }^{323}$

Although the decision in the Dietrich case constituted a radical improvement in the position of unrepresented accused persons, it falls short of formulating a right to legal representation. The majority view that the duty to ensure a fair trial derives from the court's inherent power, exposes it to several weaknesses. First, the decision to grant a stay depends on a finding that legal representation is necessary for the fair trial of an accused and is not focused upon rights belonging to the accused. The High Court determined that in the absence of "exceptional circumstances" the trial of an unrepresented accused will be unfair if (a) the accused is indigent, (b) the offense charged is a serious offense, and (c) the inability to obtain legal representation did not result from fault on the accused's part. Limiting the right to a stay to the trial of a serious offense has led later case law to decide that the conduct of committal proceedings, ${ }^{324}$ summary trials in magistrate's courts, ${ }^{325}$ and appeals without legal representation will not be unfair. ${ }^{326}$ Second, the court has discretion to grant a stay of proceedings. The right to a fair trial is not necessarily negated by the lack of legal representation. A court may refuse to grant a stay of proceedings on the basis of the availability of amicus curiae, or because there is evidence that the accused has adequate knowledge and skill to conduct his or her case properly. Third, the court's common law powers are subject to statutory alteration. Thus, state legislation such as section 360A of the Victoria Crimes Act can significantly cut into the power to grant a stay. Section $360 \mathrm{~A}(1)$ provides that the fact that "an accused has been refused legal assistance in respect of a trial is not a ground for an adjournment or stay of a trial.",327

In Dietrich, two judges of the High Court, Judge Deane and Judge Gaudron, were prepared to go further, holding that the right to a fair trial derives from the separation of judicial power within the Commonwealth Constitution. $^{328}$ However, even under that view, it is likely that a constitutional right to a fair trial would only operate as an immunity from

323. Id. at 335 (internal citations omitted).

324. State v. Canellis (1994) 181 C.L.R. 309, 311-12.

325. Weinel v. Fedcheshen (1995) 65 S.A. St. R. 146.

326. Simanovic v. R. (1998) 72 A.L.J.R. 1050; R. v. Rich (1998) 4 V.R. 44.

327. Crimes Act, $1958, \S 360 \mathrm{~A}$ (Vict.).

328. Dietrich, 177 C.L.R. at 326, 362. 
legislative interference rather than as a source of personal rights. ${ }^{329}$ Moreover, notwithstanding the hopes of some that a more widely accepted constitutional guarantee of the right to a fair trial would develop further, ${ }^{330}$ subsequent courts have declined to adopt this course. ${ }^{331}$

\section{E. The Appeals Process}

Both Australia and the United States subscribe to the belief that the appeals process is essential to a fair criminal justice system. In neither nation, though, is there a strict requirement mandating criminal appeals. ${ }^{332}$ In the United States, the ability of the indigent defendant to appeal her conviction is far more powerful. In fact, for criminal defendants, in all but the most trivial cases, the right to appeal is automatic. ${ }^{333}$ Moreover, the right cannot be unduly restricted or limited. ${ }^{334}$ In the United States, counsel must be provided to the indigent on the first appeal, ${ }^{335}$ and financial requirements cannot limit the record presented to the appellate court. ${ }^{336}$

In Australia, the right to legal representation for indigent defendants has not been extended to appeals or applications for leave to appeal. ${ }^{337}$ However, this position may soon be reconsidered given that article 14(2) of the International Covenant on Civil and Political Rights incorporates

329. See Kruger v. Commonwealth (1997) 190 C.L.R. 1 (per Brennan, C.J.), 46 (per Dawson, J.), 61 (per Gaudron, J.), 93 (per Toohey, J.), 125-26 (per McHugh, J.), 177 (per Gummow, J.).

330. E.g., The Honorable Justice K.P. Duggan, Reform of the Criminal Law with Fair Trial as the Guiding Star, 19 CRIM. L.J. 258, 272-73 (1995); James Miller, Criminal Cases in the High Court of Australia: Kable v. The Director of Public Prosecutions for New South Wales, 21 CRIM. L.J. 92, 101 (1997) (expressing the view that the decision in Kable made it more likely that state courts would refuse to apply state laws that led to the denial of a fair trial); John Toohey, A Matter of Justice: Human Rights in Australian Law, 27 U.W. AUSTL. L. REV. 129, 129-30 (1998); see also Fleming \& Pearce, supra note $320, \uparrow 12$.

331. E.g., Frugtniet v. Victoria (1997) 71 A.L.J.R. 1598, 1601-02; Chau v. Dir. Pub. Prosecutions (1995) 37 N.S.W.L.R. 639, 653-56.

332. Almost a century ago, the United States Supreme Court held that the Constitution does not require states to grant appeals as a right to criminal defendants seeking to review alleged trial court errors. See Evitts v. Lucey, 469 U.S. 387, 391-405 (1985).

333. Only a few American states do not have automatic appeals in all criminal cases. See Ross v. Moffitt, 417 U.S. 600 (1974) (discussing the discretionary review system in the United States). After the first appeal, the appeal is discretionary. See id.

334. See Griffin v. Illinois, 351 U.S. 12, 20 (1956).

335. Id. With later, discretionary appeals, however, the granting of counsel for indigents also is discretionary. Id.

336. See, e.g., Griffin, 351 U.S. at 12. The Supreme Court found that the constitution required that indigents be given free trial transcripts for the purpose of establishing an appellate record. Id. at 19-20.

337. New South Wales v. Canellis (1994) 181 C.L.R. 309, 328; see also Simanovic v. R. (1998) 72 A.L.J.R. 1050. 
the right to appeal, and has been characterized by at least one High Court judge as a feature of the right to a fair trial. ${ }^{338}$

\section{F. The Entrapment Defense}

Most of the important substantive criminal law defenses are quite similar in the United States and Australia. They both find their origin in the English common law, and the two different court systems generally apply them in a similar fashion. With regard to defense of others, self defense, necessity, or duress, there are no major differences in the two criminal justice systems. ${ }^{339}$ With the entrapment defense, however, there is a world of difference. In short, the defense is quite vibrant in the United States, but does not exist in Australia.

\section{The United States}

Federal judges almost a century ago created the entrapment defense out of concerns regarding governmental overreaching in the investigation of crimes. ${ }^{340}$ As stated by Justice Brandeis's dissent, in one of the earliest decisions in the field, courts need to intervene when a "crime [is] instigated by officers of the Government ... [when the crime] is the fruit of their criminal conspiracy to induce its commission." evolution of the defense has seen the development of two distinct substantive tests, two features of the defense are present everywhere throughout the United States. ${ }^{342}$

338. International Covenant on Civil and Political Rights, art. 14(2), Dec. 19, 1966, 999 U.N.T.S. 171, 6 I.L.M. 368 (entered into force Mar. 23, 1976, and ratified by the United States June 8, 1992); see also Sinanovic, 72 A.L.J.R. at 1051-52.

339. This does not mean that the two systems are identical. With self-defense, for instance, the application in terms of appropriate evidence appears to differ. In the United States, the courts view the defense as being objective, looking to the true reasonable person standard regarding the need for the use of force and also the degree of force to be used. The Australian courts allow greater evidence of the defendant's own individual characteristics and traits, consistent with a more subjective standard. Compare People v. Goetz, 497 N.E.2d 41, 47 (N.Y. 1986), with Conlon (1993) 69 A. Crim. Rev. 92, 93. Even here, however, the differences are not stark. With the battered victim's syndrome, for instance, both jurisdictions allow considerable expert testimony as to both objective and subjective considerations in determining if a selfdefense claim would be appropriate. See Osland v. R. (1998) 159 A.L.R. 170; Bechtel v. Oklahoma, 840 P.2d 1 (Okla. Crim. App. 1992).

340. See generally Casey v. United States, 276 U.S. 413 (1928) (Brandeis, J., dissenting). Now, however, every state in the United States has the defense, either by statute or by judicial order.

341. Id. at 423.

342. The subjective test, used by a majority of the states and in the federal system, asks whether prior to the first contact by the government agent, the defendant was otherwise predisposed to commit the crime. The objective test, used by several of the larger states such as 
The first is the remedy available if the defendant sufficiently shows governmental overreaching. ${ }^{343}$ While some nations may act to limit particular items of evidence if they find improper governmental involvement in the creation of crime, ${ }^{344}$ in the United States, courts treat entrapment as a true defense. And, as with any true defense, if the defendant prevails the court must dismiss all charges and they cannot be reinstated. Illinois's state statute provides a fairly typical example of an unambiguous entrapment rule: "A person is not guilty of an offense if his or her conduct is incited or induced by a public officer or employee, or agent of either, for the purpose of obtaining evidence for the prosecution of that person.",345

The second feature is the distaste courts have for unseemly government behavior in connection with the investigation of crime, and the concomitant willingness of American judges to intervene to prevent successful prosecutions in such cases. The two most famous opinions of the United States Supreme Court emphatically make this point. ${ }^{346}$

The defendant in Sherman v. United States was an individual known to be a recovering narcotics addict. ${ }^{347}$ Preying on his weakness and prior addiction, a government agent vigorously and frequently pursued the defendant urging him to find illegal narcotics. ${ }^{348}$ When the defendant finally responded and found such drugs, the police arrested and charged him with (and later convicted him of) a federal drug violation. ${ }^{349}$ The Supreme Court in striking down the conviction was unforgiving of the government's behavior.

The case at bar illustrates an evil which the defense of entrapment is designed to overcome. The government informer entices someone attempting to avoid narcotics not only into carrying out an illegal sale but also into returning to the habit of use. Selecting the proper time, the

California, Texas, and Michigan, asks whether the inducement of the government agent was so extreme as to make it likely that a law-abiding person might have committed a crime in response.

343. In most jurisdictions following the subjective test, government overreaching has to be found by jury. But see Jacobson v. United States, 503 U.S. 540 (1992); Sherman v. United States, 356 U.S. 369,372 (1958) (deciding as a matter of law because the evidence was clear that the defendant was not pre-disposed to commit the crime). In most jurisdictions following the objective test, overreaching by the government can be found by a trial judge. However, in states such as Iowa and Utah, the matter is given to the jury to decide. For further discussion, see MARCUS, supra note 298 , ch. 5.

344. As in Australia, where a successful entrapment like claim may result in certain narrowly defined pieces of evidence being excluded at trial. See discussion infra Part IV.F.2.

345. 720 ILL. COMP. STAT. ANN. § 5/7-12 (1993).

346. Sherman, 356 U.S. at 376; Jacobson, 503 U.S. at 553-54.

347. See Sherman, 356 U.S. at 374-75.

348. See id. at 370-71.

349. See id. at $370-72$. 
informer then tells the government agent. The set-up is accepted by the agent without even a question as to the manner in which the informer encountered the seller. Thus the Government plays on the weakness of an innocent party and beguiles him into committing crimes which he otherwise would not have attempted. Law enforcement does not require methods such as this. ${ }^{350}$

The Court in Jacobson $v$. United States also condemned the government's behavior. ${ }^{351}$ In that case, over a period of more than two years, two agencies (through five fictitious organizations and a phony pen pal) sought to determine the defendant's willingness to violate the law by ordering child pornography through the mail. ${ }^{352}$ At the end of this intensive operation, the defendant bought an illegal magazine from government officials that had been sent through the mail. ${ }^{353}$ Here, too, the Court reversed the conviction, noting:

Law enforcement officials go too far when they "implant in the mind of an innocent person the disposition to commit the alleged offense and induce its commission in order that they may prosecute." [W]e are "unable to conclude that it was the intention of the Congress in enacting this statute that its processes of detection and enforcement should be abused by the instigation by government officials of an act on the part of persons otherwise innocent in order to lure them to its commission and to punish them." When the Government's quest for convictions leads to the apprehension of an otherwise law-abiding citizen who, if left to his own devices, likely would have never run afoul of the law, the courts should intervene. $^{354}$

\section{Australia}

In Australia, the use of entrapment is largely a matter of internal control for police organizations. The government implemented limited reporting requirements when it introduced the Controlled Operations legislation at the federal level and in Queensland, South Australia, and New South Wales. ${ }^{3 s 5}$ Otherwise, there is a very limited monitoring of investigative entrapment strategies.

350. Id. at 376.

351. See Jacobson, 503 U.S. at 541.

352. Id. at 542.

353. Id. at $543-44$.

354. Id. at 553-54 (internal citations omitted).

355. Crimes Act, 1914, (Austl.); Law Enforcement (Controlled Operations) Act, 1997, $\S 23$ (N.S.W.); Police Powers and Responsibilities Act, 2000, § 172A (Queensl.); Criminal Law (Undercover Operations) Act, 1995, § 5 (S. Austl.). 
The Controlled Operations legislation followed the High Court decision in Ridgeway v. $R^{356}$ By a majority of six-to-one, the Court decided that when law enforcement officers engage in undercover operations, and as a result, commit an element of the offense with which the defendant is charged, a court should normally refuse to admit the evidence of that element against the defendant. ${ }^{357}$

The court convicted Ridgeway of importing heroin contrary to section 233B(1)(c) of the Commonwealth's Customs Act of 1901. ${ }^{358}$ Chong, a member of the anti-narcotics branch of the Royal Malaysian Police Force as part of a joint Malaysian-Australian operation, imported the heroin. ${ }^{359}$ Ridgeway had initiated and arranged the importation through Lee, whom he had met while in prison. ${ }^{360}$ The government deported Lee upon his release from prison to Malaysia. ${ }^{361}$ Following contact from Ridgeway, Lee reported to the Malaysian police. ${ }^{362}$

Chong flew in from Malaysia with the heroin, and by special arrangement with Australian Customs cleared customs restrictions. ${ }^{363}$ Several days later Chong and Lee met with Ridgeway and handed over the heroin. ${ }^{364}$

Ridgeway appealed to the High Court against his conviction on the following grounds:

1. The evidence of the heroin importation should be excluded on the ground of public policy because the police had illegally imported it; and

2. Ridgeway was entitled to a substantive defense of entrapment as the prosecution was an abuse of process. ${ }^{365}$

The Court quashed Ridgeway's conviction on the basis of his first argument. ${ }^{366}$ In relation to his second argument, the High Court held that there is no substantive defense of entrapment in Australia. ${ }^{367}$ The majority also held that the fact that the police procured the offense by

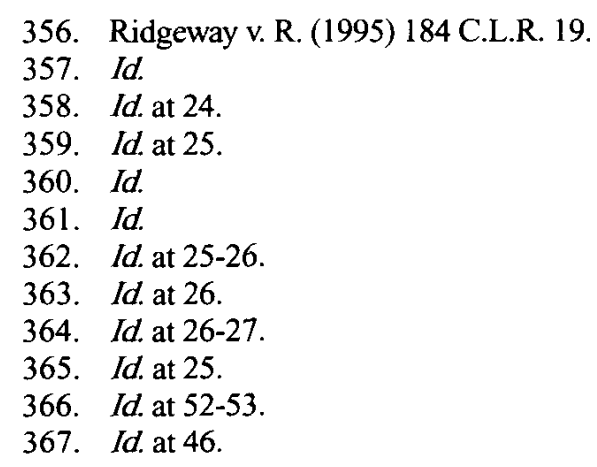


unlawful means was insufficient to stay proceedings as an abuse of process. ${ }^{368}$

Following Ridgeway there was a flurry of applications to have evidence in drug stings and prostitution cases excluded ${ }^{369}$ Although it appears that very few of these applications were successful, significant pressure was exerted by law enforcement agencies to overturn the High Court's position in Ridgeway. ${ }^{370}$ It was feared that Ridgeway would unduly inhibit the use of undercover operations and undermine drug law enforcement in particular. ${ }^{371}$ In response, the Commonwealth Parliament passed part $1 \mathrm{AB}$ of the Crimes Act of 1914, and the South Australian Parliament passed the Criminal Law (Undercover Operations) Act of 1995..$^{372}$ Later, New South Wales passed the Law Enforcement (Controlled Operations) Act of 1997 and Queensland passed the Police Powers and Responsibilities Act of 2000. ${ }^{373}$

The aim of the complementary state and federal legislation is to exempt law enforcement officers from legal liability when engaged in covert operations that involve unlawful conduct. ${ }^{374}$ The state provides immunity where senior police authorized the unlawful conduct or, in the case of Queensland, a controlled operations committee. ${ }^{375}$ This authorization, however, may only be provided on specified grounds. ${ }^{376}$ The legislation requires that the senior officer or committee must be satisfied that the target of the investigation is engaging or about to engage in serious criminal behavior, and that the nature and extent of the

368. Id. at 48.

369. See R. v. Marashi \& Jaksimoni (unreported S.A. Dist. Ct. Jt. No. D3262 May 30, 1994); R. v. Gidgeon (1995) Q.C.A. 506; Emmanuele v. Dav (1995) A.C.T.S.C. 23; Massey v. R. [No. 1] (1994) S.A. St. C. 4787. (2001).

370. Simon BronttT \& BernadetTe McSherry, Principles of Criminal LaW 873

371. Australia, Senate Legal and Constitutional Committee, Report Crimes (Controlled Operations) Bill, Sept. 1995; Australia, Parliamentary Debates, House of Representatives 1996, at 2510-21.

372. Crimes Act, 1914, § 1AB (Austl.); Criminal Law Undercover Operations Act, 1995 (S. Austl.).

373. Law Enforcement (Controlled Operations) Act, 1997 (N.S.W.); Police Powers and Responsibilities Act, 2000 (Queensl.).

374. See Law Enforcement (Controlled Operations) Act, 1997 (N.S.W.); Police Powers and Responsibilities Act, 2000 (Queensl.).

375. Crimes Act, 1914, § 15I (Austl.); Law Enforcement (Controlled Operations) Act, 1997, § 16 (N.S.W.); Police Powers and Responsibilities Act, 2000, § 179 (Queensl.); Criminal Law (Undercover Operations) Act, 1995, § 4 (S. Austl.).

376. Crimes Act, 1914, § 15M (Austl.); Law Enforcement (Controlled Operations) Act, 1997, $\S 6$ (N.S.W.); Police Powers and Responsibilities Act, 2000, $\$ 177$ (Queensl.); Criminal Law (Undercover Operations) Act, 1995, § 3 (S. Austl.). 
serious criminal behavior justifies the undercover operations. ${ }^{377}$ The Commonwealth legislation is limited to the investigation of offenses relating to narcotic goods. ${ }^{378}$ The state legislation is broader in application and covers "serious criminal behaviour."379 Section 15R of the Commonwealth's Crimes Act of 1914 requires the Minister to be notified when the Police Commissioner, Deputy Commissioner, or Assistant Commissioner authorizes a "controlled operation."380 Reasons must be given for the authorization. ${ }^{381}$ The action taken pursuant to the authorization must also be reported to the Minister under section $155^{382}$ The Act requires the Minister to report every year to Parliament on the number of authorizations and the reasons given for the authorizations under section $15 \mathrm{~T}^{383}$ Similar reporting requirements apply at the state level. ${ }^{384}$

Apart from Queensland, the legislation elsewhere does not have the effect of overturning Ridgeway. ${ }^{335}$ The principle enunciated in Ridgeway continues to operate where the Controlled Operations legislation applies, except that it has the effect of altering the balancing of public policy in favor of admission. To the extent that the legislation does not apply or that authorization is not obtained, the balance of public policy remains in favor of accepting the evidence, unless the investigating authorities procured the offense via their own unlawful or improper conduct. ${ }^{386}$

Consequently, the discretion created in Ridgeway is not a significant means to regulate entrapment. ${ }^{387}$ Apart from the fact that it

377. In South Australia and Queensland, the authorizing officer/committee must ensure that the undercover operation will not incite those without previous criminal predisposition. Criminal Law (Undercover Operations) Act, 1995, § 3(d)(ii) (S. Austl.); Police Powers and Responsibilities Act, 2000, 177 (2)(d) (Queensl.).

378. Crimes Act, 1914 (Austl.) (discussing generally the relationship between state and federal criminal investigations).

379. Law Enforcement (Controlled Operations) Act, 1997, $\S 6$ (N.S.W.); Police Powers and Responsibilities Act, 2000, $\$ 173$ (Queensl.); Criminal Law (Undercover Operations) Act, 1997, $\S 3$ (S. Austl.).

380. Crimes Act, 1914, § 15R (Austl.).

381. Id.

382. Id. $\S 15 \mathrm{~S}$.

383. Id. \& $15 \mathrm{~T}$.

384. Law Enforcement (Controlled Operations) Act, 1997, $\S 23$ (N.S.W.); Police Powers and Responsibilities Act, 2000, $\$ 172 \mathrm{~A}$ (Queensl.); Criminal Law (Undercover Operations) Act, $1995, \S 5$ (S. Austl.).

385. Section 194 of the Police Powers and Responsibilities Act of 2000 provides that evidence is not inadmissible when the police obtain it as a result of a controlled operation. Police Powers and Responsibilities Act, 2000, § 194 (Queensl.). 550 .

386. See, R. v. Giaccio (1997) 68 S.A. St. R. 484, 499; R. v. Martelli (1995) 83 A. Crim. R.

387. Ridgeway v. R. (1995) 184 C.L.R. 19. 
operates on an ad hoc basis, according to whether it is raised before a judge, it is very limited in scope. The discretion only applies to cases where the police or police agents participate in the offense with which they charge the defendant. ${ }^{388}$ According to the High Court, if the police have not engaged in an activity which itself creates an essential ingredient of the offense, it is unlikely that mere inducement will justify an exercise of the discretion to exclude, because the weight of public policy will be in favor of convicting the guilty. ${ }^{389}$ Further, the discretion to exclude is limited to evidence directly related to police illegality. ${ }^{390}$ If there is other evidence such as a confession (even where derivative of the illegal undercover operation) the defendant may still be convicted notwithstanding that the defendant's participation in the offense occurred as a result of police instigation. ${ }^{391}$ Even where the police conduct constitutes an essential element of the offense, there is little evidence that the discretion has been widely applied..$^{392}$

The subsequent South Australian Court of Appeal decision in $R . v$. Ridgeway illustrates the reluctance to limit the police use of covert techniques. ${ }^{393}$ Following the High Court decision and his release from prison, Ridgeway later was charged with possession of heroin for the purpose of sale in breach of section 32(1)(e) of South Australia's Controlled Substances Act of 1984. ${ }^{394}$

The Criminal Law (Undercover Operations) Act of 1995 was given retrospective application in South Australia and provided immunity where the undercover operation was approved by a law enforcement authority. ${ }^{395}$ The Ridgeway Court held that the controlled importation had been approved by the Australian Federal Police and accordingly, immunity applied. ${ }^{396}$ Once that had been determined, the Court held that

388. Id. at 39.

389. See id; see also R. v. Bijkerk (2000) 111 A. Crim. R. 443; R. v. Martelli (1995) 83 A. Crim. R. 550; The Queen v. Haughbro (1997) Austl. Cap. Terr. S. Ct. 112; R. v. Richards (2001) N.S.W. Ct. Crim. App. 160; R. v. Giaccio (1997) 68 S.A. St. R. 484.

390. Pavic v. The Queen, (1998) 192 C.L.R. 159, 172-73.

391. Simon Bronitt \& Declan Roche, Between Rhetoric and Reality: Sociolegal and Republican Perspectives on Entrapment, 4 INT'L J. EVID. \& ProOF 77, 80 (2000).

392. See id. (discussing how the judicial approach to investigative impropriety and entrapment remains permissive). Their study of reported and unreported cases revealed that in every case (except one) in which the court considered Ridgeway, the court exercised the discretion in favor of admitting the evidence of unlawful conduct. Id.

393. R. v. Ridgeway (1998) 71 S.A. St. R. 73.

394. Id. at 25-27.

395. As was the Commonwealth's legislation. Crimes Act, 1914, § 15x (Austl.) It was enforced by the High Court in R. v. Nicholas. R. v. Nicholas (1997) 151 A.L.R. 312.

396. Ridgeway, 71 S.A. St. R. at 45. 
the balance of public policy was in favor of admitting the evidence..$^{397}$ The Court also held that even if the Criminal Law (Undercover Operations) Act of 1995 did not apply, the exercise of the discretion favored admission of the evidence of importation against Ridgeway because the investigating police officers had not participated in an essential element of the offense. ${ }^{398}$ Consideration favoring admission included the difficulty of relying on mere surveillance to detect the offense, the seriousness, and prevalence of the offense, and that the state prosecuting authority had not participated in the illegality. ${ }^{399}$

The High Court's approach in Ridgeway and subsequent Australian cases reflects an "official-centered model" of entrapment that focuses on objective standards of probity in law enforcement. ${ }^{400}$ Under this approach, due process is defined objectively by considering whether the police engaged in criminality, rather than by considering the fairness of the process to a particular defendant within the system or the values that might provide some guidance as to the appropriate constraints on the use of covert techniques. ${ }^{401}$ In fact the High Court in Ridgeway determined that fairness was not particularly relevant, provided the police did not engage in illegal activity, and the use of deceit and subterfuge were legitimate even where they led to the incitement of an offense. ${ }^{402}$ It was only in cases where the harassment or manipulation was clearly inconsistent with minimum standards of policing and when balanced against other factors (such as the seriousness of the crime, the extent of the known criminal activity, the difficulty of effective investigation, and imminent danger to the community) that the High Court recommended exercise of discretion to exclude evidence obtained as a result of entrapment. ${ }^{403}$

Consequently, following the passage of the controlled operations legislation, judicial oversight of entrapment in Australia is extremely thin. This is consistent with the Australian judicial attitudes toward the admissibility of confessional material. Australian courts reject the role of regulating police conduct and tend to focus far more on the reliability of the material presented to them, as seen earlier.

397. Id. at 43 .

398. Id. (stating it was not essential to the crime of possessing for sale to establish that the drugs had been imported).

399. See id.

400. Andrew Ashworth, What Is Wrong with Entrapment?, 1999 SING. J. LEG. STUDS. 293, 297-317 (1999).

401. Ridgeway, 184 C.L.R. at 50-51.

402. Id. at 19,38 .

403. Id. at $50-51$. 


\section{G. Open Trials}

Both Australia and the United States are fully committed to maintaining open criminal trials, proceedings at which the defendant can put the government to the test of proving, in front of the community, guilt beyond a reasonable doubt. One can trace this commitment directly to the English system of presumptively open criminal trials. ${ }^{404}$ Both nations have always viewed openness in the criminal justice system as central, a point well made by philosopher Jeremy Bentham:

Without publicity, all other checks are insufficient: in comparison of publicity, all other checks are of small account. Recordation, appeal, whatever other institutions might present themselves in the character of checks, would be found to operate rather as cloaks than checks; as cloaks in reality, as checks only in appearance. ${ }^{405}$

Beyond those basic and indisputable philosophies, however, the differences between the United States and Australia regarding open trials are significant. This Article now turns to three distinct, but related, subjects to demonstrate those differences.

\section{Prior Restraints}

\section{a. The United States}

Trial judges in important criminal cases are often faced with serious questions of undue pretrial publicity and related concerns about the defendant's ability to receive a fair trial from an impartial jury and the difficulty of closing a trial to the public. One solution that has often been considered in the past is the entry of an order forbidding the media from publishing certain key pieces of information about the trial, prior to its termination. ${ }^{406}$ After all, if the media can be ordered to withhold stories about confessions or witness statements, both jurors and witnesses may be spared the seemingly impossible task of trying to avoid being influenced by highly material information.

Although prior American jurisprudence may have considered this response, it is rarely discussed today, but not because it is ineffective. ${ }^{407}$

404. See EdWARD Jenks \& P.B. FaIREST, THE Book OF English LAw 73-74 (6th ed. 1967) ("[O]ne of the most conspicuous features of English justice, that all judicial trials are held in open court, to which the public have free access, ... appears to have been the rule in England from time immemorial.').

405. 1 JeREMy Bentham, Rationale of Judicial EVIdENCE 524 (1978).

406. See generally Alfred Friengly \& Ronald L. GoldFarb, CRIME and Publicity, The IMPACT OF NEWS ON THE ADMINISTRATION OF JUSTICE 113-120 (1967).

407. For a comprehensive account of United States Supreme Court decisions dealing with the press and the right to a fair trial, see, DOUGLAS S. CAMPBELL, FREE PRESS V. FAIR TRIAL: 
To the contrary, it can be most effective in curbing the media. Restricting publication of this information is no longer a serious option because the courts have consistently found this to be in violation of the free speech and free press guarantees found in the First Amendment of the Constitution. ${ }^{408}$

Such a prohibition against the media is labeled a prior restraint, because it restricts speech before it occurs, rather than allowing the speech to take place and then providing punishment for the act. ${ }^{409}$ Prior restraints include "all government actions that result in the physical interception and suppression of speech prior to its public expression."110 Because it is a prior restraint, it is, and has been historically, ${ }^{411}$ considered a more drastic infringement on free speech than later punishment. ${ }^{42}$ If information relevant to the trial cannot be heard, it cannot be evaluated by the people. As a consequence, the courts scrutinize such orders with strictness, for "liberty of the press ... has meant, principally although not exclusively, immunity from previous restraints or censorship."413

This principle was well stated by the United States Supreme Court in Nebraska Press Association v. Stuart. ${ }^{414}$ The defendant was charged with the commission of a series of grisly murders. ${ }^{415}$ Not surprisingly, his arrest, charge, and trial proceedings attracted tremendous media attention in the area. ${ }^{46}$ Lawyers for both the defense and the government asked the court to enter an order limiting information being conveyed to the public. ${ }^{417}$ In response, the trial judge prohibited anyone who attended the pre-trial proceedings from "releas[ing] or authoriz[ing] the release for public dissemination in any form or manner whatsoever any testimony given or evidence adduced" before the commencement of the trial. ${ }^{418}$ The

SUPREME COURT DECISIONS SINCE 1807 (1994) (listing and relating highlights of the developments in this area of law from 1807 through 1991).

408. See Murphy v. State of Florida, 421 U.S. 794, 798 (1975); Press-Enter. Co. v. Superior Court, 464 U.S. 501, 507 (1983); U.S. CONST. amend. I. "Congress shall make no law ... abridging the freedom of speech, or of the press ...." U.S. CONST. amend. I.

409. Marin Scordato, Distinction Without a Difference: A Reappraisal of the Doctrine of Prior Restraint, 68 N.C.L. REV. 1, 30-31 (1989).

410. Id.

411. This dates all the way back to Cooley and Blackstone. See generally 3 RONALD Rotunda \& John NowaK, Treatise on CONStitutional LaW: Substance and Procedure, $\S \S 20.16,20.25$.

412. See Near v. Minnesota, 283 U.S. 697 (1930).

413. Id. at 716 .

414. Nebraska Press Ass'n v. Stuart, 427 U.S. 539 (1976).

415. Id. at 542.

416. Id.

417. Id.

418. Id. 
trial judge justified the ruling saying that "'because of the nature of the crimes charged in the complaint that there is a clear and present danger that pre-trial publicity could impinge upon the defendant's right to a fair trial." ${ }^{419}$ The state supreme court agreed with the trial court, but altered the order, limiting the prohibition to the defendant's purported confession, statements made by the defendant to others, and anything else "strongly implicative" of the defendant. ${ }^{40}$

The United States Supreme Court recognized that the state trial and appeals judges attempted to act responsibly, "out of a legitimate concern, in an effort to protect the defendant's right to a fair trial., ${ }^{, 221}$ The Justices, however, unanimously rejected the orders which had been entered by the state judges. ${ }^{422}$ To satisfy the Constitution, the Court held, the trial judge must make particular findings as to three areas: the problem of pre-trial publicity was intense, other alternatives would not limit the publicity, ${ }^{423}$ and the prior restraint would be effective in limiting the publicity. ${ }^{42}$ The Justices made clear that trial judges would have an extremely difficult time in justifying restrictive orders using this three-part analysis:

$[\mathrm{P}]$ rior restraints on speech and publication are the most serious and least tolerable infringement on First Amendment rights .... A prior restraint has an immediate and irreversible sanction. If it can be said that a threat of criminal or civil sanctions after publication "chills" speech, prior restraint "freezes" it at least for the time....

[The government must show that] further publicity, unchecked, would so distort the views of potential jurors that 12 could not be found who would, under proper instructions, fulfill their sworn duty to render a just verdict exclusively on the evidence presented in open court. ${ }^{425}$

Since the Nebraska Press decision, few trial judges have been willing to enter such "gag orders" out of concern for the free speech and press implications present with such direction. ${ }^{426}$ Recognizing the

419. Id. at 543 (internal citations omitted).

420. Id. at 540 .

421. Id. at 555 .

422. All nine Justices agreed that the pre-trial order was unconstitutional; however, three Justices would have gone further and held that no prior restraint could ever be validly directed against the media. Id. at 572 (Brennan, J., concurring).

423. See infra notes $427-428$ and accompanying text.

424. Neb. Press Ass' 'n, 427 U.S. at 562.

425. Id. at $559,569$.

426. One notable exception is the odd situation found in the CNN/Manuel Noriega case. United States v. Noriega, 917 F.2d 1543 (11 th Cir. 1990), cert. denied, Cable News Network, Inc. v. Noriega, 498 U.S. 97 (1990). During the criminal prosecution of Noriega, the former Panamanian leader, CNN obtained tapes of conversations he had with his lawyers while in prison. Id. at 1545. The trial court ordered that CNN not broadcast the tapes on television. Id. 
severity of the problems involving pre-trial publicity, trial courts have developed a series of steps, just short of a prior restraint, designed to lessen the impact of such publicity. ${ }^{427}$ These steps include continuances, change of venue, intense examination of potential jurors as to the impact of publicity, sequestering of jurors, detailed instructions to jurors regarding the need to focus exclusively on the in-court testimony, and orders limiting statements made by parties to the litigation, including lawyers. ${ }^{428}$ The only notable exceptions here relate to cases in which the court orders new trials, or prosecutions which empanel anonymous jurors, a relatively rare occurrence. ${ }^{429}$

\section{b. Australia}

The Australian approach to the concept of a fair trial is much more institutionally orientated than in the United States where the courts place greater weight on the rights to free speech and open justice. Australian jurisprudence concerning fair trials tends to be cast in terms of the necessary structural and procedural features that will protect the integrity of the trial process. ${ }^{430}$ Courts regard the principle of open justice as an important adjunct to the fair trial insofar as it inhibits the arbitrary exercise of judicial power. ${ }^{431}$ However, it does not trump other principles that also protect the integrity of the trial process such as maintenance of

Ultimately the trial judge vacated his order finding that the broadcast did not threaten the defendant's right to a fair trial. The initial order was upheld on appeal and the Supreme Court refused to stay the restraining order. Cable News Network, Inc., 498 U.S. at 976. CNN never paid the levied fine, but instead covered court costs and apologized on air for broadcasting the tapes. CNN Is Sentenced for Tapes and Makes Public Apology, N.Y. TIMES, Dec. 20, 1994, at B7.

427. See Irvin v. Dowd, 366 U.S. 717, 723 (1961). In Irvin, the Court found that the trial judge had substantial obligations to limit pre-trial publicity where the defendant was "tried in an atmosphere ... [with a] huge wave of public passion and by a jury ... in which two-thirds of the members admit, before hearing any testimony, to possessing a belief in his guilt." Id. at 728 . The pre-trial publicity there was overwhelming, affecting virtually every citizen called as a potential juror. Id. at 723 .

428. See generally Paul Marcus, The Media in the Courtroom: Attending, Reporting, Televising Criminal Cases, 57 IND. L.J. 235, 235-44 (1982).

429. See United States v. Barnes, 604 F.2d 121 (2d Cir. 1979), cert. denied, 446 U.S. 907 (1980); United States v. Thornton, 1 F.3d 149 (3d Cir. 1993); People v. Goodwin, 69 Cal. Rptr. 2d 576 (Cal. Ct. App. 1997); Commonwealth v. Angiulo, 615 N.E.2d 155 (Mass. 1993).

430. See Jago v. N.S.W. Dist. Court (1989) 168 C.L.R. 23, 30-31 (per Mason, C.J.), 47-48 (per Brennan, J.), 71-72 (per Toohey, J.); Dietrich v. The Queen (1992) 177 C.L.R. 292, 299-300 (per Mason, C.J. \& McHugh, J.), 363 (per Gaudron, J.); Kable v. Dir. Pub. Prosecutions New South Wales (1995) 189 C.L.R. 51.

431. See Dickason v. Dickason (1913) 17 C.L.R. 50; Russell v. Russell (1976) 134 C.L.R. 495, 505; Nicholas v. The Queen (1998) 193 C.L.R. 173, 208-09 (per Gaudron, J.); John Fairfax Publications v. Attomey-Gen. New South Wales (2000) 181 A.L.R. 694. 
the impartiality of the fact finder. ${ }^{432}$ As one would expect from institutionally based jurisprudence, unbridled media power is regarded as more of a danger than arbitrary exercise of judicial power. ${ }^{433}$

Directly contrary to the practice in the United States, Australian courts are inclined to approach the danger of unbridled media power on the basis that prevention is better than cure. The remedial techniques preferred by U.S. courts to redress the actual dangers that may arise when media coverage undermines a defendant's due process rights, such as sequestration and questioning of jurors on the effect of pre-trial publicity, ${ }^{434}$ are not generally practiced in Australia where they are seen as an impediment to the efficiency of the trial process. ${ }^{435}$

The sub judice rule, a branch of contempt law, operates as the major Australian prophylactic. As outlined by the High Court in Hinch v. Attorney General (Victoria), it is a contempt of court to publish material that has a tendency to prejudice legal proceedings. ${ }^{436}$ It is not necessary to show that actual prejudice has occurred as a result of a media publication. ${ }^{47}$ Prejudice may arise if the material published could affect the testimony of potential witnesses, embarrass judicial officers presiding over the trial, or influence members of the jury. ${ }^{438}$ Examples of breaches of the sub judice rule include:

1. Publishing photographs of persons accused of criminal offenses when it is likely that the identity of the assailants may come into question ${ }^{439}$

2. Disclosure of voir dire revelation $\mathbf{s}^{40}$

3. Publication of a pre-trial interview with a witness by one of the parties $^{41}$

4. Publication of past convictions ${ }^{42}$

432. R. v. Tait (1979) 46 F.L.R. 386, 404; Mirror Newspapers v. Waller (1985) 1

N.S.W.L.R. 1, 12-13.

433. See id

434. Michael Chesterman, Freedom of Speech in Australian LaW: A delicate PLANT 271 (2000).

435. See Murphy v. The Queen (1988) 167 C.L.R. 94, 99-100 (per Mason, C.J. \& Toohey, J.), 123 (per Brennan, J.).

436. Hinch v. Attorney-Gen. (Vict.) (1987) 164 C.L.R. 15, 34 (per Wilson, J.), 46 (per

Deane, J.), 70 (per Toohey, J.), 88 (per Gaudron, J.).

437. Id. at 46 .

438. Id. at 55 .

439. R. v. ABC; Davies Brothers; Northern Television (TNT 9) \& Tasmanian Television

(Unreported Supreme Court of Tasmania 2 Nov. 1983).

440. See R. v. Day \& Thomson (1985) V.R. 261.

441. See Attorney-Gen. v. Mirror Newspapers, Ltd. (1980) 1 N.S.W.L.R. 375, 390.

442. See Hinch, 164 C.L.R. at 15. 


\section{Publication of an alleged confession ${ }^{43}$}

It may also amount to contempt if media publications prejudge issues before the court, regardless of whether the publications have the tendency to undermine due process. ${ }^{44}$

Despite its potential for stifling media commentary upon criminal trials, the sub judice rule is limited in application. The rule only applies while the trial is pending and during the currency of the trial. ${ }^{45}$ It does not operate after the trial when a defendant has exhausted all avenues of appeal. ${ }^{446}$ There will also be no contempt if the publication constitutes a fair and accurate report of court proceedings made in good faith. ${ }^{47}$ Furthermore, if the potential prejudice that the publication might cause is outweighed by the public interest in discussing or disseminating information about the case, the publication will not constitute contempt. ${ }^{48}$ For example, in Attorney General v. John Fairfax Publications Pty. Ltd., an investigative article about a new drug boss in Sydney did not amount to contempt (even though the man in question was facing drug charges at the time of publication) because the article did not discuss the particular facts and circumstances surrounding the charges. ${ }^{49}$

The sub judice rule has not been a particularly effective prophylactic because Australian courts seem resigned to the fact that it is impossible to hermetically seal juries from the influence of the media. ${ }^{{ }^{450}}$ As a result, a number of jurisdictions have passed statutory provisions to suppress the publication of specific information such as the names and addresses of the victim, witnesses, or accused, and evidence that might

443. See Attorney-Gen. v. TCN Channel Nine (1990) 20 N.S.W.L.R. 368.

444. This rule, known as the "pre-judgment" rule, is of doubtful application, although some Australian judges have supported the existence of this additional basis for contempt liability. E.g., Watts v. Hawke \& David Syme \& Co. (1976) V.R. 707; Commercial Bank of Austl. v. Preston (1980) 2 N.S.W.L.R. 554; Victoria v. Australian Bldg. Constr. Employees \& Builders Labourers' Fed'n (1982) 152 C.L.R. 25, $167-68$ (per Brennan, J.); Hinch, 164 C.L.R. at 54-55 (per Deane, J.) (expressing the view that pre-judging issues have a tendency to prejudice a fair trial and that accordingly prejudging should be subsumed within the general Hinch test). Id.

445. James v. Robinson (1963) 109 C.L.R. 593, 608.

446. See id.

447. See Cassidy v. Mercury Newspapers, Pty, Ltd. (1968) T. St. R. 198; The Queen v. Pearce (1992) 7 W. Austl. R. 395.

J.).

448. Hinch, 164 C.L.R. at 22-25 (per Mason, C.J.), $37-42$ (per Wilson, J.), 57 (per Deane,

449. John Fairfax Publications, 181 A.L.R. at 318, ๆף 128, 134; see also Sun Newspapers, Ltd. v. Murray (1992) 58 A. Crim. R. 281, 288-89.

450. Murphy v. The Queen (1989) 167 C.L.R. 94, 99 (per Mason, C.J. \& Toohey, J.). 
later be excluded at trial. ${ }^{451}$ These statutory provisions are related to, but broader in application than, the sub judice rule as they operate to ensure the proper administration of justice. The proper administration of justice not only incorporates the facilitation of a fair trial, but also incorporates interests such as the need to report crime, facilitate proper law enforcement, protect victims of crime, and protect national security. ${ }^{452}$ The statutory provisions are also much more effective than the sub judice , rule as they identify and prevent the dissemination of particular information, while the sub judice rule is usually applied after it is breached. ${ }^{45}$

Nonetheless, apart from South Australia where the basis for obtaining suppression orders is particularly broad, Australian courts do not make suppression orders frequently. ${ }^{454}$ Even in South Australia which issues approximately two hundred suppression orders per annum, the principle of open justice receives primacy. ${ }^{45}$ The general distress and suffering associated with involvement in court proceedings has been held insufficient to justify issuing a suppression order. ${ }^{456}$

The prophylactic approach taken under Australian law assumes that the courts are best placed to regulate media coverage through devices such as suppression orders and the deterrent threat of contempt proceedings. $^{457}$ It also reflects Australian courts' lack of faith in the efficacy of remedial measures employed by U.S. courts. ${ }^{458}$ Whether Australian criminal trials are less transparent than U.S. criminal trials,

451. E.g. Federal Court of Australia Act, 1976, $\S 50$ (Austl.); Evidence Act, 1971, §§ 8284 (Austl. Cap. Terr.); Crimes Act, 1900, § 578-578A (N.S.W.); Evidence Act, 1939, § 57(1) (N. Terr. Austl.); Evidence Act, 1929, §69A (S. Austl.); County Court Act, 1958, $\S \S 80-80 A A$ (Vict.); Supreme Court Act, 1986, §§ 18-19 (Vict.); Justices Act, 1902, § 101C (W. Austl.); Evidence Act, 1906, $\S \S 11 \mathrm{~A}, 36 \mathrm{C}$ (W. Austl.). The power of courts to restrict publication at common law is doubted. See $R e$ 'Mr. C.' (1993) 67 A. Crim. R. 562; Raybos v. Jones (1985) 2 N.S.W.L.R. 47; John Fairfax \& Sons Ltd. v. Police Tribunal (New South Wales) (1986) 5 N.S.W.L.R. 465, 477; Rockett v. Smith (1992) 1 Q.R. 660.

452. CONTEMPT BY PubliCATION $\S 10.57$ (N.S.W. Law Reform Comm'n Discussion Paper No. 43, 2000) [hereinafter CONTEMPT BY PUBLICATION].

453. The Attorney-General, or a person with a special interest, in the trial may apply for an injunction to prohibit the publication of specified material under the sub judice rule, but this is rarely done because of the difficulty of passing the requisite burden of proof. TCN Channel Nine, 20 N.S.W.L.R. at 368.

454. Evidence Act, 1929, §69A (S. Austl.); ConTEMPT BY PUBliCATION, supra note 452, \ 10.72.

455. Attorney General of South Australia, Report Made Pursuant to Section 71 OF THE EVIDENCE ACT, 1929 RELATING TO SUPPRESSION ORDERS (JUNE 30, 2000).

456. Advertiser Newspapers Ltd. v. Bunting (2000) S.A. S. Ct. 458, $\mid 16$.

457. See Johnston v. Cameron (2002) F. Ct. Austl. 251, 2002 WL 1904419; Cheatle \& Sturdy v. Davy (1989) 51 S.A. St. R. 155; G. v. The Queen (1984) 35 S.A. St. R. 349, 352 (per King, C.J.)

458. See Marcus, The Media in the Courtroom, supra note 428. 
however, ultimately depends on the breadth and quality of the media scrutiny they receive.

\section{Closure Orders}

\section{a. The United States}

Two constitutional principles make it extremely difficult for an American trial judge to order a criminal trial, or any nontrivial criminal proceeding, closed to the public and the media. The first is the Sixth Amendment right to an open trial, and the second is the First Amendment right to freedom of speech and the press. ${ }^{459}$ The former right is of the accused, the latter is of the public. ${ }^{460}$ Together, these rights have been construed by the U.S. courts to create an almost impossibly high hurdle which must be overcome before any closure order will be allowed. ${ }^{461}$ It is a curious constitutional analysis to see the courts utilize the two specific rights together in order to create a "presumption of openness [which] inheres in the very nature of a criminal trial."'

The requirement of an open trial extends to most of the proceedings attached to the trial itself, ${ }^{463}$ including almost all pretrial matters. ${ }^{464}$ When

459. U.S. CONST. amends. I, VI.

460. Id.

461. See infra notes $490-491$ and accompanying text.

462. Richmond Newspapers, Inc. v. Virginia, 448 U.S. 555, 556 (1980).

463. The Supreme Court has spoken forcefully of the need for open hearings:

When a shocking crime occurs, a community reaction of outrage and public protest often follows. Thereafter the open processes of justice serve an important prophylactic purpose, providing an outlet for community concern, hostility, and emotion. Without an awareness that society's responses to criminal conduct are underway, natural human reactions of outrage and protest are frustrated and may manifest themselves in some form of vengeful "self-help," as indeed they did regularly in the activities of vigilante "committees" on our frontiers. "The accusation and conviction or acquittal, as much perhaps as the execution of punishment, operat[e] to restore the imbalance which was created by the offense or public charge, to reaffirm the temporarily lost feeling of security and, perhaps, to satisfy that latent "urge to punish."'

Civilized societies withdraw both from the victim and the vigilante the enforcement of criminal laws, but they cannot erase from people's consciousness the fundamental, natural yearning to see justice done-or even the urge for retribution. The crucial prophylactic aspects of the administration of justice cannot function in the dark; no community catharsis can occur if justice is "done in a corner [or] in any covert manner." It is not enough to say that results alone will satiate the natural community desire for "satisfaction." A result considered untoward may undermine public confidence, and where the trial has been concealed from public view an unexpected outcome can cause a reaction that the system at best has failed and at worst has been corrupted. To work effectively, it is important that society's criminal process "satisfy the appearance of justice," and the appearance of justice can best be provided by allowing people to observe it.

Id. at 571-72 (internal citations omitted). 
a court contemplates closure, even for a portion of the proceeding, the law requires the court to look to the facts of the specific case and make particular findings which support closure: ${ }^{.65}$

[T] he party seeking to close the hearing must advance an overriding interest that is likely to be prejudiced, the closure must be no broader than necessary to protect that interest, the trial court must consider reasonable alternatives to closing the proceeding, and it must make findings adequate to support the closure. ${ }^{466}$

Very few recent U.S. trials, even notorious prosecutions, ${ }^{467}$ have been conducted in less than a fully open fashion. ${ }^{468}$ To be sure, the trend has

464. See Press-Enter. Co. v. Superior Court, 464 U.S. 501, 512 (1984); Press-Enter. Co. v. Superior Court (II), 478 U.S. 1, 14 (1986). Courts view grand jury proceedings as investigatory rather than accusatory and thus, are not open. Id.

465. The findings must show that "there is a substantial probability that the defendant's right to a fair trial will be prejudiced by publicity that closure would prevent and, second, reasonable alternatives to closure cannot adequately protect the defendant's fair trial rights." Press-Enter. Co. II, 478 U.S. at 14.

466. Waller v. Georgia, 467 U.S. 39, 48 (1984). The findings must demonstrate "that closure is essential and narrowly tailored." Bell v. Jarvis, 198 F.3d 432, 440 (4th Cir. 1999).

467. Consider, for instance, these trials which were widely publicized, and completely open:

1. O.J. Simpson, murder;

2. Theodore Kaczynski, the "unibomber";

3. Jeffrey Dahmer, serial killer;

4. Andrea Yates, pleaded insanity defense after drowning her children;

5. John Hinckley, attempted assassination of President Reagan;

6. Timothy McVeigh, Oklahoma City bombing;

7. Colin Ferguson, mass killings on New York railroad;

8. Louise Woodward, British nanny accused of killing a child;

9. John duPont, killing of Olympic wrestler;

10. Marv Albert, television broadcaster tried for sexual battery.

Several recent matters make the point with clarity. In one of the most intense issues of recent times, sixty-five priests in the Boston area were accused of sexually abusing children. Rejecting a request by the Archdiocese of Boston, a judge ordered that 11,000 documents regarding the matters be made available to the public. Pam Belluck, Judge Denies Church's Bid to Seal Records on Priests, N.Y. TIMES, Nov. 26, 2002, at A18.

Similarly, the court ordered open hearings in the case involving the daughter of Florida Governor Jeb Bush (niece of United States President George W. Bush). Responding to claims that the proceedings should be closed because of the rehabilitative concerns of a drug court status hearing, the court wrote:

$[T]$ here is a strong presumption that almost all court proceedings are open to the public and the press.... "[P]ublic access to the courts is an important part of the criminal justice system, as it promotes free discussion of governmental affairs by imparting a more complete understanding to the public of the judicial system [and] the people have a right to know what occurs in the courts."

State of Florida v. Bush, Case \#48-02-CF-6371-0, Order Denying Motion to Close Drug Court Proceedings, 8, 14 (Fla. 9th cir. Ct. Oct. 15, 2002) (internal citations omitted). See also the Court of Appeals ruling reversing the trial judge's decision to close the voir dire examination of potential jurors in the Martha Stewart case. The court explained the strong need for keeping 
been to open the trials even further, with many states ${ }^{469}$ allowing the televising of court hearings. ${ }^{40}$ During this time, the United States has seen the creation of a cable network designed for the purpose of televising court actions. ${ }^{471}$

\section{b. Australia}

Although Australian courts apply both common law ${ }^{472}$ and statutory powers $^{473}$ to restrict access to their proceedings, as a matter of practice, the courts use these powers sparingly. That "justice should not only be done, but should manifestly and undoubtedly be seen to be done" is an aphorism often repeated within the Australian legal community. ${ }^{474}$ Consequently, legislation requiring that proceedings be held in camera without considering the primacy of open justice would be struck down as

criminal trials open. A.B.C. Inc. v. United States, 360 F.3d 90 (2d Cir. 2004). In perhaps the most widely reported criminal case in recent years, involving the Washington, D.C. "snipers" prosecutions, the judge ordered that preliminary proceedings involving the juvenile defendant be kept open. See Maria Glod, Malvo Case Hearing to Stay Open, WASH. PoST, Jan. 11, 2003, at B1; see also infra notes $491-492$ and accompanying text.

468. The trial judge will normally look for an alternative to closure such as the possibility of a change of venue (as in the Timothy McVeigh prosecution where the case was moved from Oklahoma City to Denver, or the Washington D.C. "sniper" prosecutions where the cases were moved from one area of Virginia to another) or more intense questioning of jurors, the voir dire process. United States v. McVeigh, 153 F.3d 1166 (10th Cir. 1998); see In re Washington Post Motion to Open Juvenile Detention Hearing, 247 F. Supp. 2d 761 (D. Md. 2003); see also infra notes 518-519 and accompanying text.

469. See, e.g., N.Y. JUD. LAW § 218; Cook v. First Morris Bank, 719 A.2d 724 (N.J. Super. 1998). The federal courts do not, however, permit televisions in the courtrooms.

470. In most states, the matter is given to the trial court's discretion, as the judge can "forbid coverage whenever satisfied that coverage may have a deleterious effect on the paramount right of the defendant to a fair trial." Chandler v. Florida, 449 U.S. 560, 566 (1981).

471. Court TV, when selecting trials for television coverage, looks to factors such as: how important and interesting the issues in the case are; the newsworthiness of the case and the people involved; the quality and educational value of the trial; and the expected length of the trial. COURTROOM Television Network LlC, Frequently ASKed Questions About Court T.V., htpp://www.courttv.com/about/ctvfaq.html (last visited Oct. 3, 2003).

472. Scott v. Scott (1913) C.L.R. 417, 436; Dickason v. Dickason (1913) 17 C.L.R. 50, 50 51; Russell v. Russell (1976) 134 C.L.R. 495, 503; David Syme \& Co. v. Gen. Motors-Holden's Ltd. (1984) 2 N.S.W.L.R. 294, 299-300 (per Street, J.); Raybos v. Jones (1985) 2 N.S.W.L.R. 47, 50-53 (per Kirby, J.).

473. Federal Court of Australia Act, 1976, § 17(4) (Austl.); Evidence Act, 1971, §§ 82, 83(2) (Austl. Cap. Terr.); Supreme Court Act, 1970, $\$ 80$ (N.S.W.); Supreme Court Act, 1979, $\S 17$ (N. Terr. Austl.); Evidence Act, 1939, §57(1) (N. Terr. Australia); Supreme Court of Queensland Act, 1991, § 128 (Queensl.); Evidence Act, 1929, § 69(1) (S. Austl.); Supreme Court Act, 1986, $\$ \S 18-19$ (Vict.); Bail Act, 1982, § 20 (W. Austl.); Criminal Code Act, 1913, $\S 635 \mathrm{~A}(2)$ (W. Austl.).

474. The King v. Sussex Justices Ex parte McCarthy (1924) LR 256, 259; Hon. J.J. Spigelman, Seen to Be Done: The Principle of Open Justice Part I, 74 AUSTL. L.J. 290, 293 (2000). 
unconstitutional. ${ }^{475}$ The principle of open justice will prevail, except to the point where the administration of justice becomes impractical. For example:

If the very openness of court proceedings would destroy the attainment of justice in the particular case (as by vindicating the activities of the blackmailer) or discourage its attainment in cases generally (as by frightening off blackmail victims or informers) or would derogate from even more urgent considerations of public interest (as by endangering national security) the rule of openness must be modified to meet the exigencies of the particular case. ${ }^{46}$

Australian courts generally prefer to use devices such as pseudonyms to refer to confidential or secret information ${ }^{477}$ as well as the use of suppression orders to safeguard specific information rather than using blanket closure. ${ }^{478}$ The courts have remained open even where the evidence before them has been unsavory, or would cause embarrassment or harm to those involved. ${ }^{479}$

Members of the Australian media have no greater array of privileges than members of the public. Consequently, Australia restricts the media's access to information more than the United States does. Moreover, Australian courts tend to manage the media to a greater degree through the use of public relations officers and media officers. ${ }^{480}$ Courts permit members of the media to attend court and to take notes on testimony. ${ }^{481}$

475. See John Fairfax Publications Pty. Ltd. v. Attorney-Gen. New South Wales (2000) N.S.W. Ct. App. 198 (holding that section 101A of the Supreme Court Act of 1970 was invalid insofar as it required that appeals from an acquittal for contempt by the Attorney-General were to be heard in camera). The New South Wales Court of Appeal, relying on Kable v. D.P.P., determined that section 101A was incompatible with the exercise of the judicial power of the Commonwealth. John Fairfax Group Pty. Ltd. v. Local Court of New South Wales (1991) 26 N.S.W.L.R. 131, 141 (per Kirby, J.); see also Cain v. Lars [No 2] (1985) 3 N.S.W.L.R. 230, 246 (stating proceedings were held in camera to protect police informer); R. v. Socialist Worker Printers \& Publishers Ltd., Ex parte Attorney-Gen. (1975) Q.B. 637, $651-52$ (stating proceedings were held in camera to protect blackmail victim); Attorney-Gen. v. Leveller Magazine Ltd. (1979) A.C. 440 (stating proceedings were held in camera to protect national security); R. v. McGrath (2001) Q.R. 131 (stating proceedings were held in camera to protect identity of defendant who had co-operated with the police).

476. John Fairfax Group v. Local Court of New South Wales (1991) 26 N.S.W.L.R. 131, 141 (per Kirby, J.).

477. The Australian media does not have general access to documents kept on file in court proceedings: Smith v. Harris (1996) 2 V.R. 335; Ex Parte Titelius v. Pub. Serv. Appeal Bd. (1999) 21 W.A.R. 201

478. See CONTEMPT BY PUBLICATION, supra note 452, $\uparrow 10.12$

479. See Raybos v. Jones (1985) 2 N.S.W.L.R. 47, 59 (per Kirby, J.), 61-62 (per Samuels, J.), 63-64 (per Priestly, J.); R. v. Chief Registrar of Friendly Societies (1984) Q.B. 227; The Queen v. Tait (1979) 46 E.L.R. 386;. R. v. Hamilton (1930) 30 (N.S.W.) St. R. 277.

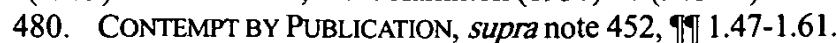

481. CHESTERMAN, supra note 434 , at $254-55$. 
However, the media does not have the right to photograph witnesses or to televise proceedings, ${ }^{482}$ and the media has no access to documents that are not read out in open court. ${ }^{483}$ Should the court proceed in camera, publication of what occurred would constitute contempt of court. ${ }^{484}$

\section{Secrecy for Jurors}

a. The United States

As in Australia, the criminal justice system in the United States sees the jury as a central tenant. While trials do not resolve most criminal cases ${ }^{485}$ virtually all citizens appear convinced that jurors are essential players in determining the guilt of accused individuals. ${ }^{486}$ The right to trial by jury is an explicit guarantee in the Constitution, and has been vigorously extolled by virtually every public figure in the nation. ${ }^{487}$ As noted by the United States Supreme Court in perhaps its most famous statement on the subject:

482. It is in contempt to film proceedings except with the permission of the court, but courts rarely give permission: Wendy Harris, Don't Rush to Judgment on Court TV in the O.J. Simpson Aftermath, 3 Media L. REP. 1 (1995); DANIEL STEPNIAK, EleCtronic MEdia CoVERAGE OF COURTS: A REPORT PREPARED FOR THE FEDERAL COURT OF AUSTRALIA (1998).

483. Smith v. Harris (1996) 2 V.R. 335; Ex Parte Titelius, W.A.R. at 201.

484. $\operatorname{ReF}(1977)$ All E.R. 114, 122-23.

485. While the numbers vary from state to state, guilty pleas nationwide dispose of criminal cases about two-thirds of the time. EXAMINING THE WORK OF STATE CourTs, 2002: A National Perspective from the Court Statistics Project (Brian J. Ostrom et al., eds. 2003), http://www.ncsconline.org/D.Research/csp/2002_Files/2002_Criminal.pdf; U.S. DEP'T OF JUSTICE, COMPENDIUM OF FEDERAL JUSTICE STATISTICS (2002), available at http://www.ojp.usdoj. gov/bjs/pub/pdf/cfjs0004.pdf. A leading criminal procedure treatise states:

[T] he great majority of criminal cases are disposed of by plea of guilty rather than by trial. Sometimes this plea is the result of nothing more than implicit plea bargaining in that the defendant enters his plea merely because it is generally known that this is the route to a lesser sentence. But more common is explicit bargaining in which the defendant enters a plea of guilty only after a commitment has been made that concessions will be granted (or at least sought) in his particular case.

Wayne LaFave et al., Criminal Procedure 956 (3d ed. 2000).

486. See Janet Stidman Eveleth, Will Jury Reforms Attract More Jurors?, 33 MD. B.J. 42 (2000): "According to an American Bar Association 1998 public opinion poll, ' 78 percent of the public rates our jury system as the fairest way to determine guilt or innocence, and 69 percent consider juries to be the most important part of the justice system."' Id. at 44 (internal citations omitted).

487. The Sixth Amendment to the United States Constitution states that "In all criminal prosecutions, the accused shall enjoy the right to a speedy and public trial, by an impartial jury of the State and district wherein the crime shall have been committed." U.S. CONST. amend. VI. However, the guarantee is not absolute. See Duncan v. Louisiana, 391 U.S. 145 (1968). A jury trial is not required in all criminal prosecutions, as the Supreme Court has consistently excluded prosecutions for "petty offenses" from the mandate. Id. at 160. 
[B]y the time our Constitution was written, jury trial in criminal cases had been in existence in England for several centuries and carried impressive credentials traced by many to Magna Carta. Its preservation and proper operation as a protection against arbitrary rule were among the major objectives of the revolutionary settlement which was expressed in the Declaration and Bill of Rights of 1689.

…

Jury trial came to America with English colonists, and received strong support from them. Royal interference with the jury trial was deeply resented.

The Declaration of Independence stated solemn objections to the King's making "Judges dependent on his Will alone, for the tenure of their offices, and the amount and payment of their salaries," to his "depriving us in many cases, of the benefits of Trial by Jury," and to his "transporting us beyond Seas to be tried for pretended offenses."

The constitutions adopted by the original States guaranteed jury trial. Also, the constitution of every State entering the Union thereafter in one form or another protected the right to jury trial in criminal cases. ${ }^{48}$

Even skeletal history provides impressive support for declaring the right to a jury trial in criminal cases as fundamental to our system of justice. The Court has noted, for example: "Those who emigrated to this country from England brought with them this great privilege 'as their birthright and inheritance, as a part of that admirable common law which had fenced around and interposed barriers on every side against the approaches of arbitrary power." $" 489$

Jury trials continue to receive strong support. The laws of every state guarantee the right to trial by jury in serious criminal cases. ${ }^{490}$ No state has dispensed with it, nor are there significant movements underway to do so. ${ }^{491}$

While both nations recognize the right to trial by jury, the rights in practice are considerably different. As noted above, Australian lawyers have limited access to information about jurors and do not participate extensively in the voir dire process. In the United States, however, lawyers generally are active in the process, often with considerable pretrial information about jurors. ${ }^{492}$

488. Id. at $151-53$.

489. Id. at 154 (internal citations omitted).

490. See id. at 151-54.

491. See id. at 151-59.

492. See generally ABA Standards for Criminal Justice Fair Trial and Free Press 83.5 (3d ed. 1992) (noting accompanying commentary, particularly Standards 8-3.5, 8-3.6). A 
The greatest difference may be the ability of the public to gather information about the jury determination process after the jury has reached a verdict. It is routine for U.S. jurors to make public announcements after major trials, describing their own thought processes and the evidence presented by both sides. ${ }^{493}$ Whether in the form of books written about the O.J. Simpson trial, ${ }^{494}$ or news conferences held after the Arthur Andersen prosecution, ${ }^{49}$ it is not uncommon to hear about criminal trials from the jurors' viewpoints.

Once again, the influence of the free speech provision of the First Amendment is evident in the practices adopted in the U.S. criminal justice system. ${ }^{496}$ Trial judges rarely issue broad orders prohibiting jurors from speaking with the media at a trial's conclusion, nor do they direct media representatives to avoid seeking interviews. ${ }^{497}$ When courts enter such orders, they are invariably struck down on the grounds that they

high publicity espionage trial discussed in an Associated Press article demonstrates the point again, Jury Pool in Espionage Trial Asked Thoughts About Death Penalty, Dallas MorNing NEws, Jan. 13, 2003, available at http:/www.dallasnews.com/cgi-bin/bi/gold_print.cgi. For a broad discussion of the need, generally, to avoid limiting disclosure of jurors' identities, see State v. Tucker, 657 N.W.2d 374 (Wis. 2003).

493. There are many current instances of this occurring. The most specific and obvious instances of this are the statements recently made by the jurors in the D.C. "sniper" cases. See Tamara Jones, Jury Recommends Death Penalty in Muhammed Trial, WASH. Post Nov. 24, 2003, at A1; James Dao, Sniper Jury Cites Lack of Sorrow for Death Sentence, N.Y. TIMES, Nov. 25, 2003, at A1; Adam Liptak, Young Sniper Given Sentence of Life Term, N.Y. TiMES, Dec. 24, 2003 , at A1.

494. A few of the jurors who participated in O.J. Simpson's case wrote books describing their reactions to the evidence and to the lawyers, as well as to the deliberative process. See, e.g., AMANDa CoOley et al., Madam Foreman: A Rush to Judgment? (1995); MiChaEl KNOX \& Mike Walker, The PrIVATE DIARY OF AN O.J. JUROR: BeHIND THE SCENES Of THE TRIAL OF THE CENTURY (1995). In addition, the media conducted numerous press conferences with jurors soon after the verdict in the case. See Juror: 'O.J. Simpson didn't do it', CNN.COM, Oct. 4, 1995, available at www.cnn.com/US/OJ/daily/9510/10-04/moran/.

495. See Associated Press, Andersen's Conviction Could Kill It, CBSNEWS.com, June 15, 2002, available at http://www.cbsnews.com/stories/2002/06/10/national/printable511769. shtml.

496. The point was well made in Butterworth v. Smith, 494 U.S. 624 (1990). Florida had enacted a statute essentially prohibiting a witness from ever disclosing the testimony he had given to the grand jury. Id. While the case involved grand jury proceedings rather that the usual trial jury deliberations, the point may even be stronger in that context for the Justices recognized that "the proper functioning of our grand jury system depends upon the secrecy of the grand jury proceedings." Id. at 630 . Still, the Court unanimously struck down the law. Id. at 624 . In response to the argument that courts require secrecy as a matter of security for the subject of the grand jury investigation, the Justices wrote, "When an investigation ends, there is no longer a need to keep information from the targeted individual in order to prevent his escape-that individual presumably will have been exonerated, on the one hand, or arrested or otherwise informed of the charges against him, on the other." Id. at 632 . One would think that this principle would apply with equal force to the juror in a criminal case once the defendant has been tried.

497. See infra notes 498-502 and accompanying text. 
"encompassed every possible juror interview situation." $\$ 98$ To be valid, such orders must "reflect an impending threat of jury harassment rather than a generalized misgiving about the wisdom of such interviews.",499 See, for instance, In re The Express-News Corp., where the trial judge issued a broad restrictive order concerning interviews of former jurors. ${ }^{500}$ The appeals court invalidated the order:

The rule is unlimited in time and in scope, applying equally to jurors willing and anxious to speak and to jurors desiring privacy, forbidding both courteous as well as uncivil communications, and foreclosing questions about a juror's general reactions as well as specific questions about other jurors' votes that might, under at least some circumstances, be inappropriate. $^{501}$

Restrictive orders are generally only entered and upheld when they narrowly restrict discussion either of the views of specific jurors (other than the person being interviewed), or of the process itself, as opposed to the reactions and observations of the interviewed person. ${ }^{502}$

Perhaps the best illustration of the relative ease with which U.S. jurors can convey thoughts about their experience may be found in connection with death penalty prosecutions. Throughout the nation, in work sponsored by the Capital Jury Project, researchers have spoken at length with more than a thousand individuals who have served as jurors in capital cases. ${ }^{503}$ One of the authors of this Article pursued the most recent research in Virginia. ${ }^{504}$ There, law students conducted intensive interviews with sixteen capital jurors concerning the jurors' views about the process, the evidence, the roles of the lawyers and judges, and the deliberations that took place. ${ }^{505}$

498. Contra Costa Newspapers v. Superior Court Contra Costa County, 72 Cal. Rptr. 2d 69, 73 (Cal. App. 1st Dist. 1998).

499. United States v. Antar, 38 F.3d 1348, 1364 (3d Cir. 1994)

500. In re The Express News Co., 695 F.2d 807 (5th Cir. 1982).

501. Id. at 810 .

502. See United States v. Cleveland, 128 F.3d 267, 270 (5th Cir. 1997). The court was careful to note that the order was limited to forbidding discussion about "deliberations" which refers only to the discussions about the case occurring among jurors within the sanctity of the jury room. Id. "A juror in this case may be interviewed about his own 'general reactions' to the trial proceedings ... [and the order] does not purport to prevent jurors from speaking out on their own initiative." Id

503. See Ursula Bentele \& William J. Bowers, How Jurors Decide on Death: Guilt Is Overwhelming; Aggravation Requires Death; and Mitigation Is No Excuse, 66 BroOK. L. REv. 1011, 1017 (2001).

504. See Stephen P. Garvey \& Paul Marcus, Virginia's Capital Jurors, 44 WM. \& MarY L. REV. 2063 (2003).

505. Id. at 2089-98. 
b. Australia

The criminal trial jury has been described by the High Court as a "fundamental institution in our traditional system of justice" whose primary function is to protect citizens from the overzealous exercise of authority by the government. ${ }^{506}$ Paradoxically, however, it is an institution that operates in secrecy and with little accountability. Nevertheless, an overwhelming majority of Australians regard trial by jury as the fairest way to judge a criminal trial. ${ }^{507}$ That faith rests upon the independence of the jury, and, consequently, its implicit lack of bias. ${ }^{508}$ However, when comparing the Australian and U.S. systems, the mechanisms for ensuring impartiality and representativeness seem rather underdeveloped in Australia. In Australia, the courts select potential jurors at random from the electoral roll, although a substantial number of occupations are exempted. $^{509}$ There are also grounds to apply to be excused from jury duty. ${ }^{\text {s10 }}$ As a result, the range of persons eligible for jury duty is not representative of the community at large.

According to Australian practice, the only inquiries made of empanelled jurors concern:

1. whether the venireman is related to or knows the accused/victim/prosecutor/defense counsel/principal witnesses involved in the case; and

2. whether the venireman knows of any reason why he or she cannot render a verdict in accordance with the evidence. ${ }^{511}$

These inquiries are made orally on an informal basis while the veniremen sit in the body of the court. Individual views on the matter to be tried cannot be examined, except where a prima facie case has been established to show cause for challenging a particular juror. ${ }^{512}$ Lawyers

506. Brown v. The Queen (1986) 160 C.L.R. 171, 197 (per Brennan, J.); Kingswell v. The Queen (1985) 159 C.L.R. 264, 301 (per Deane, J.).

507. G. Wilkinson, Majority Verdict in Favour of System, Herald Sun, Feb. 3, 1995, at 22-23.

508. Australia also accepts jury nullification of the law. Yager v. The Queen (1977) 139 C.L.R. 28, 38-39 (per Barwick, C.J.).

509. E.g., Jury Exemption Act, 1965 (Austl.); Jury Act, 1977, § 6 (N.S.W.); Jury Act, 1995, $\S 4$ (Queensl.); Juries Act, 1927, §§12-13 (S. Austl.); Juries Act, 2000, § 5 (Vict.); Juries Act, 1957, § 5 (W. Austl.).

510. E.g., Jury Act, 1977, § 7 (N.S.W.); Jury Act, 1995, §§ 19-23 (Queensl.); Juries Act, 1957, 5 (W. Austl.); Juries Act, 2000, 88 (Vict.).

511. Mark Findlay, Jury Management in New South Wales 44 (1994).

512. Murphy v. The Queen (1989) 167 C.L.R. 94, 104 (per Mason, C.J. \& Toohey, J.); Connell v. The Queen [No 6] (1994) 12 W.A.R. 133, 162-68; Bush v. The Queen (1993) 43 F.C.R. $549,551$. 
rarely make challenges for cause because of the difficulty in obtaining evidence about jurors. ${ }^{513}$ While defense and prosecution counsel retain the right of preemptory challenge,$^{514}$ the practice of jury vetting is limited to matters related to disqualification; therefore, counsel cannot exercise this right on any rational basis other than a desire to have a jury composed of people who look like the right sort of people to sit in judgment. ${ }^{515}$ Indeed, the Australian jury is a relatively anonymous body to those directly involved with the trial.

The inability to examine jurors' views is consistent with the secrecy surrounding jury deliberations. Jury deliberations are not recorded nor are they made available in any Australian jurisdiction. ${ }^{516}$ It is an offense to elicit comments from jurors concerning the trial or their deliberations. ${ }^{517}$ Publication in most jurisdictions of jurors' identities, or information concerning jury deliberations, is illegal. ${ }^{518}$ Evidence from jurors about their deliberations is inadmissible. ${ }^{519}$

Australia inherited the anonymity and secrecy surrounding the jury from England that remains consistent with current English practice. ${ }^{520}$ Historically, anonymity and secrecy originated in the shift from the selfinforming jury to the trial-informing jury. ${ }^{521}$ Once jurors changed from neighbors who investigated the case and formed views on liability prior

513. John Bishop, Criminal Procedure 498 ( $2 \mathrm{~d}$ ed. 1998).

514. The number of preemptory challenges that the defense and prosecution counsel may exercise varies from state to state:

1. Juries Act, 1927, $\S 61$ (S. Austl.) -3 preemptory challenges each;

2. Juries Act, 1995, $\S 42$ (Queensl.) - 2 preemptory challenges each;

3. Jury Act, $1977, \S 42$ (N.S.W.) - 3 preemptory challenges each;

4. Juries Act, $1957, \S 38$ (W. Austl.) - 5 preemptory challenges each;

5. Juries Act, 2000, $\S \S 38-39$ (Vict.) - 6 preemptory challenges each, if one is accused.

515. See Katsuno v. The Queen (1999) 199 C.L.R. 40, 50-51.

516. Brendan Cassidy, Juries: Speaking Some Thoughts on Removing the "Gag" on Jury Deliberations, 25 ALTERNATIVE L.J. 9, 9-10 (2000).

517. Juries Act, 1967, § 42C(3) (Austl. Cap. Terr.); Jury Act, 1977, § 68A (N.S.W.); Juries Act, $2000, \S 49 \mathrm{~A}-\mathrm{B}$ (N. Terr. Austl.); Jury Act, 1995, § 70(3) (Queensl.); Criminal Law Consolidation Act, 1935, § 246(3) (S. Austl.); Juries Act, 2000, §89(1)(b) (Vict.); Juries Act, 1957, § 56C (W. Austl.).

518. Juries Act, $\S 42 C(4) 1967$ (Austl. Cap. Terr.); Jury Act, 1977, §§ 68, 68B (N.S.W.); Juries Act, 2000, $\S \S 49 A-B$ (N. Terr. Austl.); Jury Act, 1995, § 79(2) (Queensl.); Criminal Law Consolidation Act, 1935, § 246(4) (S. Austl.); Juries Act, 2000, § 78(1)(a) (Vict.); Juries Act, $1957, \S 56 \mathrm{D}$ (W. Austl.). Tasmania is the only jurisdiction without this offense.

519. Evidence Act, 1995, § 129(4) (Austl.) (also codified in New South Wales and Australian Capital Territory); Ellis v. Deheer (1922) 2 K.B. 113, 115-17; R. v. Thompson (1962) 1 All E.R. 65, 66; In Re Donovan's Application (1957) V.R. 333, 336-37; In Re Matthews \& Ford (1973) V.R. 199; R. v. Challinger (1989) 2 Q.R. 352; Matta v. R. (1995) 119 F.L.R. 414.

520. Contempt of Court Act, 1981, §8 (Eng.).

521. NORMAN F. CANTOR, IMAGINING THE LAW: COMMON LAW AND THE Foundations OF THE AMERICAN LEGAL SYSTEM 195 (1997). 
to attending court to a body of persons without connection to the matter determining the issues according to the evidence presented at trial, secrecy was considered a necessary adjunct to protect them from importuning or oppression. ${ }^{522}$ Secrecy was also considered a necessary adjunct to the greater democratization of jury selection that followed the shift to the trial-informing jury. ${ }^{523}$ When jurors became selected at random from large urban populations bringing with them various backgrounds and views, it was inevitable that factual findings would become the product of compromise and that some would rest on premises contrary to legal and moral norms. It was feared that exposure of such deliberations would undermine public confidence in the criminal justice system and deleteriously effect the finality of decision-making. ${ }^{524}$

The fear that wider community participation in the jury might affect the quality of jury verdicts provides a partial explanation for the development of divergent practices in the United States. ${ }^{525}$ Whereas the Anglo-Australian criminal justice system regards secrecy as a necessary rampart for democratization, ironically openness is seen as a palliative to democratization in the United States by providing greater accountability. ${ }^{526}$ The incongruity of these positions has been attributed to "differences in social conditions growing largely out of heterogeneity of population and extent of territories." 527 However, while that might apply as between the United States and England, it does not apply between the United States and Australia, which also has a comparatively heterogeneous population diffusely spread over a large land mass. ${ }^{528}$

Constitutional protection within the Sixth Amendment is another explanation put forward for the development of divergent practices in the United States on the basis that enshrining the right to a jury within a democratically-oriented constitution provides a stronger foundation to develop mechanisms that enhance participation and transparency. ${ }^{529}$

522. The Honorable Justice McHugh, Jurors' Deliberations, Jury Secrecy, Public Policy and the Law of Contempt, in THE JURY UNDER ATTACK 56, 62-65 (Mark Findlay \& Peter Duff eds., 1988) (proposing that secrecy is necessary to facilitate frank discussion in the jury room and thus encourages better decision-making).

523. The Honorable Justice McHugh argues that to preserve public confidence in the criminal justice system requires jury secrecy. Id. at 62 .

524. Contra Cassidy, supra note 516, at 11-13.

525. CANTOR, supra note 521, at 198.

526. See infra notes 531-532 and accompanying text.

527. Roger D. Moore, Voir Dire Examination of Jurors, 17 GEO. L.J. 13, 36 (1928-1929).

528. Sebastian Clark, Addendum to ManNing Clark, A ShORT History of Australia 328,335 (4th ed. 1995).

529. Vict, Law Reform Comm., Jury Service in Victoria Final Report 7.4-7.12 (1997). 
However, again, while that explanation might apply as between England and the United States, it is not applicable as between the United States and Australia where section 80 of the Australian Constitution guarantees a right to be tried by jury at least for serious criminal offenses created by federal law. ${ }^{530}$

A more likely explanation lies in the lurking political distrust Americans harbor for the establishment (including the judiciary). ${ }^{531}$ From independence, the American jury has been seen as a political weapon. $^{532}$ To ensure its efficacy under this premise, accountability through the examination of jurors' credentials and transparency of decision-making became a required formality of due process. ${ }^{533}$ Although the jury is also valued in Australia by accused persons for peer empathy, it is not so highly valued as an essential component of the democratic system. Except for the most serious criminal cases, jury trials are rare. ${ }^{534}$

\section{TRYING TO EXPLAIN THE DIFFERENCES}

To this point we have reviewed the many structural similarities in the criminal justice systems of Australia and the United States. This Article has also analyzed the several highly significant differences in the judicial systems of the two nations. We now offer two distinct perspectives on the reasons for those differences.

\section{A. A U.S. Point of View}

Seymour Martin Lipset, in his seminal work, American Exceptionalism, writes that " $[\mathrm{t}]$ he United States is exceptional in starting from a revolutionary event, in being 'the first new nation,' the first colony, other than Iceland, to become independent., ${ }^{, 535}$ It is that exceptional foundation that helps explain why the American viewpoint of the criminal justice system is starkly at odds with the views of

530. See R. v. Archdall \& Roskruge Ex parte Carrigan \& Brown (1928) 41 C.L.R. 128.

531. See, e.g., comments from the United States Supreme Court in Duncan v. Louisiana, 391 U.S. 145, 156 (1968); Paul D. Carrington, The Seventh Amendment: Some Bicentennial Reflections, U. CHI. LEGAL F. 74 (1990).

532. Alexis de Tocqueville, Trial by Jury in the United States Considered as a Political Institution, in DEMOCRACY IN AMERICA 280-97 (rev. 1948); LYSSANDER SPOONER, AN ESSAY ON THE TRIAL BY JURY 1-19 (1989).

533. See SPOONER, supra note 532, at 1-19.

534. Wayne Westling \& Vicki Waye, Promoting Fairness and Efficiency in Jury Trials, 20 CRIM. L.J. 127, 127 (1996). omitted).

535. SEYMOUR MARTIN LiPSET, AMERICAN EXCEPTIONALISM 18 (1996) (internal citations 
Australians (as well as those of citizens in other common law based nations). Thus, while all share similar opinions about the stakes present in crafting a fair criminal justice system, the founding of America more than two centuries ago, when the need for independence seemed extremely urgent, heavily influences the stakes present for Americans. ${ }^{336}$ This founding based on independence led to an "emphasis on individual rights," which greatly shaped the rules and policies found today in the U.S. criminal justice system. ${ }^{537}$

Alexis de Tocqueville commented long ago on the role of the United States Constitution, its preeminent position in American society, and its influence on all important aspects of that society. ${ }^{538}$ While the notion of rights in the people hardly originated with the American Founding Fathers, the role of the United States Constitution and its explicit statement of citizen rights (especially in connection with criminal prosecutions) can best be understood by looking at the early American reaction to the period of English rule. ${ }^{539}$ As the President of the American Bar Association put it: "A reading of recent biographies of founding fathers John Adams, Thomas Jefferson and their junior, John Marshall, underlines a theme often missed in civics texts-their loathing of the king's courts.".540

One could easily add to this statement a hatred of the broad powers of the law enforcement community and the limited right of review of these powers. As noted earlier, these concerns inspired the Bill of Rights guarantees, including: limitations on searches; statements as to rules concerning confessions; and the roles of counsel, judge, and jury, among

536. The United States Supreme Court stated: "[W]e are forced to resolve a conflict between two fundamental interests of society; its interest in prompt and efficient law enforcement, and its interest in preventing the rights of its individual members from being abridged by unconstitutional methods of law enforcement." Spano v. New York, 360 U.S. 315, 315 (1959).

537. Alfredo Garcia, The Fifth AMEndment-A COMPREHENSIVE ApProach 32 (2002); LIPSET, supra note 535, at 21 (noting that the "American revolutionary libertarian tradition does not encourage obedience to the state and the law").

538. De Tocqueville, supra note 532, at 101.

In the United States the Constitution governs the legislator as much as the private citizen: it is the first of laws, it cannot be modified by a law; and it is therefore just that the tribunals should obey the Constitution in preference to any law. This condition belongs to the very essence of the judicature; for to select that legal obligation by which he is most strictly bound is in some sort the natural right of every magistrate.

Id.

539. "The idea of rights that was formally articulated in America in 1776 had European roots." Louis Henkin, Revolutions and Constitutions, 49 LA. L. REv. 1023, 1024 (1989).

540. Alfred P. Carlton, Jr., Uniquely American, A.B.A. J., May 2003, at 8. 
others. $^{541}$ It is this reaction to the British control over the colonists (a reaction the Australians appeared never to have experienced), which seems to be chief among the reasons for the U.S. structured system of criminal justice, complete with numerous important safeguards. ${ }^{542}$ In short, this led in the United States, but not in Australia, as noted later, to a compact between the state and its people. And, a compact is not simply a statement of responsibilities and powers of the State, but rather an agreement or covenant between the State and its citizens.

That compact is based on the idea of rights. One astute observer has written that in the early days of the nation, "whereas democracy and representative government grew gradually, rights were fundamental. ${ }^{\$ 443}$ It was the notion of rights that became the centerpiece of U.S. society, with

541. See U.S. Const. amends. I-X.

542. One can also properly offer other reasons. Numerous commentators have explored the close ties of the Americans and French in the period before the two revolutions, and the great influence of French philosophers on the Drafters of the Declaration of Independence, the Constitution, and the Bill of Rights. See, e.g., Henkin, supra note 539, at 1023-34; Terence Marshall, Human Rights and Constitutional Government: A Franco-American Dialogue at the Time of the Revolution, in THE LEGACY OF THE FRENCH REVOLUTION 151 (Hancock \& Lambert eds., 1996); Rodolfo Batiza, Onigins of Modem Codification of the Civil Law: The French Experience and Its Implications for Louisiana Law, 56 TuL. L. Rev. 477, 477-601 (1981). See generally James Q. Whitman, Harsh Justice: Criminal Punishment and the Widening DIVIDE BETWEEN AMERICA AND EUROPE 170-73 (2003).

543. Henkin, supra note 539, at 1034; United States v. Verdugo-Urquidez, 494 U.S. 259, 287-88 (1990) (Brennan, J., dissenting) (exploring the historical basis).

In drafting both the Constitution and the Bill of Rights, the Framers strove to create a form of Government decidedly different from their British heritage. Whereas the British Parliament was unconstrained, the Framers intended to create a Government of limited powers. The colonists considered the British government dangerously omnipotent. After all, the British declaration of rights in 1688 had been enacted not by the people, but by Parliament. Americans vehemently attacked the notion that rights were matters of "favor and grace," given to the people from the Government.

Thus, the Framers of the Bill of Rights did not purport to "create" rights. Rather, they designed the Bill of Rights to prohibit our Government from infringing rights and liberties presumed to be pre-existing. The Fourth Amendment, for example, does not create a new right of security against unreasonable searches and seizures.... The focus of the Fourth Amendment is on what the Government can and cannot do, and how it may act.

Id. (internal citations omitted) [emphasis in original]. The Founders, early in the nation's beginnings, recognized the need to restrain government. For example, as stated in Federalist Paper No. 51:

In framing a government which is to be administered by men over men, the great difficulty lies in this: you must first enable the government to control the governed; and in the next place oblige it to control itself. A dependence on the people is, no doubt, the primary control on the government; but experience has taught mankind the necessity of auxiliary precautions.

AlEXANDer Hamilton, John Jay, \& James Madison, The Federalist: A COMmentary ON THE CONSTItUTION OF THE United States, No. 51, 335, 337 (Random House, 1787). 
the inevitable result that "America began and continues as the most antistatist, legalistic and rights-oriented nation." ${ }^{544}$ This rights-orientation is evident in many aspects of the American culture but perhaps nowhere as clearly as in the criminal justice system ${ }^{545}$ To be sure, it is highlighted in perhaps the most famous criminal justice decision ever delivered by the United States Supreme Court, Miranda v. Arizona. ${ }^{546}$ In the very first sentence of the Miranda opinion, the Court made clear that the government must look carefully at the relevant rights before a successful criminal prosecution can occur: "The cases before us raise questions which go to the roots of our concepts of American criminal jurisprudence: the restraints society must observe consistent with the Federal Constitution in prosecuting individuals for crime. ${ }^{\text {\$47 }}$

The presence of a clear expectation of rights, combined with a massive mistrust of government, exerts tremendous impact on the American criminal justice system; an impact, as one can see, that is simply not present elsewhere in the common law world. ${ }^{548}$ There should not be any doubt; this mistrust is legendary but real, mighty and omnipresent. Jefferson spoke of it: "[t]hat government is best which

544. LIPSET, supra note 535, at 20. The point is developed further in GARCIA, supra note 537 , at 32-33.

545. Indeed, the view of rights being vital can be seen by the creation of rights not explicitly laid out by the Founders. Richmond Newspapers, Inc. v. Virginia, 448 U.S. 555 (1980). "For example, the rights of association and of privacy, the right to be presumed innocent, and the right to be judged by a standard of proof beyond a reasonable doubt in a criminal trial, as well as the right to travel, appear nowhere in the Constitution or Bill of Rights." Id. at 579-80. They are implicit in enumerated guarantees. Id at 580 .

546. Miranda v. Arizona, 384 U.S. 436 (1966).

547. Id. at 439; see also Kuk Cho, Reconstruction of the English Criminal Justice System and its Reinvigorated Exclusionary Rules, 21 LoY. L.A. INT'L \& COMP. L. REV. 259, 299 (1999):

Americans view the state with suspicion and the law as their shield against official transgressions. They expect "total justice": compensation for every harm suffered, observance of due process when their rights are at stake.... The English, on the other hand, do not yet seem to define themselves as holders of rights nor do they view their interactions with others as legal relationships... . If Americans want "total justice," expectations of justice in Britain, according to one English observer, are at best "patchy" "Due Process" is not a term which features in an English lawyer's daily vocabulary, nor is it part of a layman's demands upon life.

Id. at 299 (citing The King v. Warckshall, 1 Leach C.C., at 1324-25 (footnotes omitted)).

548. The presence pre-dates the Declaration of Independence and the Constitution. As Professor Garcia has carefully laid out, it is found in earlier state constitutions and even in colonial charters. GARCIA, supra note 537, at 14. Professor Garcia goes on to state:

[The] Virginia Declaration of Rights of 1776 ... represented an attempt to codify the individual rights the colonist deemed essential to liberty ... [it] was the precursor to the federal Bill of Rights. As such, it was bound up with the rebellion against England and represented an attempt to shield Americans from arbitrary government power. 
governs the least, because its people discipline themselves." ${ }^{499}$ John Adams railed against the seemingly limitless power of the sovereign, ${ }^{500}$ it is routinely a part of the political system "[I]t is almost obligatory for American politicians of both the right and the left to profess mistrust of government."'s51 Mistrust certainly finds its way into the rulings of American judges in criminal courts: "A right to jury trial is granted to criminal defendants in order to prevent oppression by the Government. Those who wrote our constitution knew from history and experience that it was necessary to protect against unfounded criminal charges. ... [The right to a jury trial responds to] [f]ear of unchecked power."ss.

In Brewer v. Williams, an important right to counsel decision, the Supreme Court spoke of the need "to have the protective shield of a lawyer between himself and the awesome power of the State."553 The point is also supported by Coppedge v. United States, one of the lesser known right to appeal decisions. ${ }^{554}$ The Court stated, "When society acts to deprive one of its members of his life, liberty or property, it takes its most awesome steps. ... The methods we employ in the enforcement of our criminal law have aptly been called the measures by which the quality of our civilization may be judged."sss

The application of the rights catalogued earlier in this Article is certainly not cost free. It makes the government's task in prosecuting criminals more difficult, and may result in the release of guilty and dangerous individuals from custody. ${ }^{556}$ Americans have, however, been

549. Jefferson spoke often of the mistrust of government and the need of the people to control their own destiny. Letter from Thomas Jefferson to Dr. Price (Jan. 8, 1789), in THE LIFE AND SElECTED Writings of ThOMAS JefFERSON, at 418 (Adrienne Koch \& William Peden eds., 1993). "[W]henever the people are well-informed, they can be trusted with their own government ..." Id. He regularly warned of abuses of constitutional power. See id.

550. "They have no other fortification against wanton, cruel power: no other indemnification against being ridden like horses, fleeced like sheep, worked like cattle, and fed and clothed like swine and hounds: No other defense against fines, imprisonments, whipping posts, gibbets, bastinadoes and racks." John Adams, Clarendon, no. 3 in 1 THE FOUNDERS' CONSTITUTION 17.12 (1987), available at http://press-pubs.uchicago.edu/founders/documents/ v1ch17s12.html (last visited Mar. 10, 2004).

551. Mary Ann Glendon, Rights in Twentieth Century Constitutions, in THE BlLL OF Rights IN THE MODERN STATE 525 (Geoffrey Stone et al. eds., 1992).

552. Duncan v. Louisiana, 391 U.S. 145, 155-66 (1968) (internal citations omitted).

553. Brewer v. Williams, 430 U.S. 387, 409 (1977).

554. Coppedge v. United States, 369 U.S. 438, 449 (1962).

555. Id.

556. Lakeside v. Oregon, 435 U.S. 333, 342 (1978) (Stevens, J., dissenting).

A system of law that not only makes certain conduct criminal, but also lays down rules for the conduct of the authorities, often becomes complex in its application to individual cases, and will from time to time produce imperfect results, especially if one's attention is confined to the particular case at bar. Some criminals do go free 
willing to pay that price in order to insure the preservation of liberty for citizens and substantial limitations on the government. ${ }^{557}$ Indeed, there is a substantial body of U.S. judicial writing devoted to discussing the cost of not applying important individual rights in the criminal justice setting. ${ }^{558}$ One Justice wrote: "[We have] the deep-rooted feeling that the police must obey the law while enforcing the law; that in the end life and liberty can be as much endangered from illegal methods used to convict those thought to be criminals as from the actual criminals themselves..,559 Another commented: "If the exercise of constitutional rights will thwart the effectiveness of a system of law enforcement, then there is something very wrong with that system." 560

The classic statement of the need for the government to obey the law remains that given by Justice Brandeis: ${ }^{561}$

In a government of laws, existence of the government will be imperiled if it fails to observe the law scrupulously. Our Government is the potent, the omnipresent teacher. For good or for ill, it teaches the whole people by its example. Crime is contagious. If the Government becomes a lawbreaker, it breeds contempt for law; it invites every man to become a law unto himself; it invites anarchy. To declare that in the administration of the criminal law the end justifies the means - to declare that the Government may commit crimes in order to secure the conviction of a private criminal-would bring terrible retribution. Against that pernicious doctrine this Court should resolutely set its face..$^{562}$

These views of the limits on the powers of government, and the fear of unlimited powers, can be seen in the individual criminal justice areas already discussed. Much has been written in connection with searches and seizures and the need to control government. In Camera $v$. Municipal Court, the Court noted, "The basic purpose of [the Fourth Amendment] . . . is to safeguard the privacy and security of individuals

because of the necessity of keeping government and its servants in their place. That is one of the costs of having and enforcing a Bill of Rights. This country is built on the assumption that the cost is worth paying, and that in the long run we are all both freer and safer if the Constitution is strictly enforced.

Williams v. Nix, 700 F.2d 1164, 1173 (8th Cir. 1983), rev'd on other grounds, 467 U.S. 431 (1984), quoted with approval in United States v. Lebrun, 306 F.3d 545, 554 (8th Cir. 2002).

557. LiPSET, supra note 535, at 49 (quoting Stephen Cole, Crime as the Cost of American Creativity, NewSDAY, Aug. 24, 1983, at Viewpoint Section). Cole went on to write that this emphasis on individual rights "also gives Americans a degree of civil liberty not found in most other countries." Id.

558. See infra notes 559-560 and accompanying text.

559. Spano v. New York, 360 U.S. 315, 320-21 (1959).

560. Escobedo v. Illinois, 378 U.S. 478, 490 (1964).

561. Olmstead v. United States, 277 U.S. 438, 491 (1928) (Brandeis, J., dissenting).

562. Id. at 485 . 
against arbitrary invasions by governmental officials." ${ }^{.563}$ One can easily find many similar statements: "The Fourth Amendment to our Constitution prohibits 'unreasonable' government interference with the fundamental facet of individual liberty." ${ }^{964}$ In the same year the Court stated, "The security of one's privacy against arbitrary intrusion by the police - which is at the core of the Fourth Amendment-is basic to a free society." The Court later went on to elaborate, "A sane, decent, civilized society must provide some such oasis [from governmental encroachment], some shelter from public scrutiny, some insulated enclosure, some enclave, some inviolate place which is a man's castle."\$66

The statements are similar when the discussion moves toward the controversial remedy for Fourth Amendment violations, the exclusionary rule. In the seminal case of Mapp v. Ohio, the Court wrote that applying the rule to the states was necessary, for "without that rule the freedom from state invasions of privacy would be so ephemeral ... as not to merit this Court's high regard as a freedom 'implicit in the concept of ordered liberty." 567 This sort of remark had been routinely made prior to Mapp, for example, the Justices wrote that the "purpose [for the exclusionary rule] is to deter-to compel respect for the constitutional guaranty in the only effectively available way by removing the incentive to disregard

563. Camera v. Mun. Court, 387 U.S. 523, 528 (1967).

564. Alderman v. United States, 394 U.S. 165, 202 (1969) (acknowledging the famous words of Justice Jackson in Brinegar v. United States):

Among deprivations of rights, none is so effective in cowing a population, crushing the spirit of the individual and putting terror in every heart. Uncontrolled search and seizure is one of the first and most effective weapons in the arsenal of every arbitrary government. And one need only briefly to have dwelt and worked among a people possessed of many admirable qualities but deprived of these rights to know that the human personality deteriorates and dignity and self-reliance disappear where homes, persons and possessions are subject at any hour to unheralded search and seizure by the police.

Brinegar v. United States, 338 U.S. 160, 180-81 (1949).

565. Wolf v. Colorado, 338 U.S. 25, 27 (1949).

566. Silverman v. United States, 365 U.S. 505, 512 (1961) (quoting United States v. On Lee, 193 F.2d 306, 315-16 (2d Cir. 1951) (Frank, J., dissenting)).

567. Mapp v. Ohio, 367 U.S. 643, 655 (1961) (internal citations omitted). A Justice's view of the exclusion rule in scholarly form is similar:

To give effect to the Constitution's prohibition against illegal searches and seizures, it may be necessary for the judiciary to remove the incentive for violating it. Thus, it may be argued that although the Constitution does not explicitly provide for exclusion, the need to enforce the Constitution's limits on government- to preserve the rule of lawrequires an exclusionary rule.

Potter Stewart, The Road to Mapp v. Ohio and Beyond: The Origins, Development and Future of the Exclusionary Rule in Search-and-Seizure Cases, 83 ColuM. L. ReV. 1365, 1384 (1983) (internal citations omitted). 
it." ${ }^{\prime 68}$ The point has been just as routinely made after Mapp, as when Justice Stevens wrote in his concurring opinion in Dunaway v. New York, "[J]ustification for the exclusion of evidence obtained by improper methods is to motivate the law enforcement profession as a whole-not the aberrant individual officer-to adopt and enforce regular procedures that will avoid the future invasion of the citizen's constitutional rights." $\$ 69$

The language of U.S. courts regarding the rights-based doctrine and the mistrust of government has been especially strong in the many cases exploring the validity of confessions. Whether analyzing the Due Process Clauses of the Constitution, or the Miranda view of the privilege against self incrimination, the judicial attitude is striking. ${ }^{570}$ In the Supreme Court's Jackson v. Denno decision, the majority wrote:

It is now inescapably clear that the Fourteenth Amendment forbids the use of involuntary confessions not only because of the probable unreliability of confessions that are obtained in a manner deemed coercive, but also because of the strongly felt attitude of our society that important human values are sacrificed where an agency of the government, in the course of securing a conviction, wrings a confession out of an accused against his will. ${ }^{\text {st }}$

The Court had earlier explained that "[t]his insistence upon putting the government to the task of proving guilt by means other than inquisition was engendered by historical abuses which are quite familiar.",512 Justice Brennan went even further, writing that "it is monstrous that courts should aid or abet the law-breaking police officer., ${ }^{973}$

To be sure, the Supreme Court destroyed any doubt as to the continued validity of rights-based jurisprudence with confessions, in Dickerson v. United States. ${ }^{574}$ There the defendant asked the Court to

568. Elkins v. United States, 364 U.S. 206, 217 (1960); see also, Harris v. United States, 331 U.S. 145, 198 (1947) (Jackson, J., dissenting). Here the Court recognized the conflicting interest:

Of course, this, like each of our constitutional guaranties, often may afford a shelter for criminals. But the forefathers thought this was not too great a price to pay for that decent privacy of home, papers and effects which is indispensable to individual dignity and self-respect. They may have overvalued privacy, but I am not disposed to set their command at naught.

Id.

569. Dunaway v. New York, 442 U.S. 200, 221 (1979) (Stevens, J., concurring).

570. See Miranda, 384 U.S. at 436.

571. Jackson v. Denno, 378 U.S. 368 , 385-86 (1964) (internal citations omitted) (citing Blackburn v. Alabama, 361 U.S. 199, 207 (1960)).

572. Blackburn v. Alabama, 361 U.S. 199, 207 (1960).

573. Harris v. New York, 401 U.S. 222, 232 (1971) (Brennan, J., dissenting).

574. Dickerson v. United States, 530 U.S. 428 (2000). 
limit or overrule Miranda and find that it was not constitutionally based so that Congress could legislatively alter it. ${ }^{575}$ This the Justices refused to do, concluding that the Miranda Court had

emphasized that it could not foresee "the potential alternatives for protecting the privilege which might be devised by Congress or the States," and it accordingly opined that the Constitution would not preclude legislative solutions that differed from the prescribed Miranda warnings but which were "at least as effective in apprising accused persons of their right of silence and in assuring a continuous opportunity to exercise it.,"576

A final example of the degree to which U.S. judges adhere to concerns regarding government overreaching, as well as a rights based criminal justice system, may be the most telling of all. ${ }^{577}$ The entrapment defense is a privilege found nowhere else in the community of common law nations, but one which is well preserved in the United States. ${ }^{578}$ It is striking because it is not a limitation as to evidence, but a certifiable full defense for a crime the defendant has clearly committed. ${ }^{579}$ This is not constitutionally based, nor is it found in codified form in many U.S. jurisdictions. ${ }^{580}$ Still, judges in the United States rely heavily on the entrapment doctrine: "When the Government's quest for convictions leads to the apprehension of an otherwise law-abiding citizen who, if left to his own devices, likely would have never run afoul of the law, the courts should intervene."\$81 Indeed, the whole purpose for the entrapment defense "is to deter impermissible police conduct." Brandeis, the entrapment defense should stop a prosecution "in order to protect the Government. To protect it from illegal conduct of its officers. To preserve the purity of its courts." ${ }^{, 583}$

575. Id. at 428

576. Id. at 440 (internal citations omitted).

577. Numerous other examples could be offered regarding the anti-government attitudes which find their way into important judicial decisions. See, e.g., Press-Enter. v. Superior Court, 464 U.S. 501, 508 (1984); Globe Newspaper Co. v. Superior Court County of Norfolk, 457 U.S. 596, 606 (1982); Duncan v. Louisiana, 391 U.S. 145, 155-56 (1968); Maryland v. Balt. Radio Show, Inc., 338 U.S. 912, 920 (1950) (dissent from denial of cert.).

578. Jacobson v. United States, 503 U.S. 540 (1992).

579. See generally id. (showing how some states actually require the defendant to admit to the crime in order to claim the defense).

580. See id.

581. Id. at 553-54.

582. Bradley v. Duncan, 315 F.3d 1091, 1095 (9th Cir. 2002).

583. Casey v. United States, 276 U.S. 413, 425 (1928); see also Olmstead v. United States, 277 U.S. 438, 485 (1928) (Brandeis, J., dissenting). 


\section{B. An Australian Point of View}

Although Australia and the United States share a common heritage, there are fundamental differences between the way Britain colonized them, founded them, and the relationship that subsequently developed between state and subject that provides a basis for understanding the distinct approach to criminal procedure each nation has chosen to adopt. Complimenting the divergent constitutional history are cultural differences that stem from a myriad of influences including geographic isolation and dependence on Great Britain, the so called "tyranny of distance" 184 within Australian borders, Australia's "lucky" history, its abundance of natural resources, ${ }^{585}$ and the ethos of mateship. ${ }^{586}$

Australia had no revolutionary struggle to gain national independence. ${ }^{57}$ An amalgamation of independent English colonies operating on the Australian mainland later became the various states and territories of Australia. ${ }^{58}$ The British designed the amalgamation to enhance national security, promote free trade, and facilitate economic efficiency rather than to liberate from an unwanted colonial yoke. ${ }^{589}$ There was no battle with an oppressive imperial power. ${ }^{590}$ Australia was isolated from French revolutionary influences of "liberty, equality and fraternity," which had dominated the thinking of the Drafters of the United States' Constitution. ${ }^{591}$ Rather the Australian constitutional drafting process essentially served the interests of an agricultural and commercial elite, which arguably still continue to dominate Australian society today. ${ }^{592}$

Nonetheless, the French Revolution and the American Revolution were important catalysts in Australian history. ${ }^{593}$ These events provided the motivation for a harsh militarily operated prison system that

584. See generally Geoffrey Blainey, The TyranNy of Distance: How Distance SHAPED AUSTRALIA's HISTORY (1983). (1964).

585. See generally DONALD HORNE, THE LUCKY COUNTRY: AUSTRAlia IN THE SIXTIES

586. Jim Page, Is Mateship a Virtue?, 37 Australian J. SOC. Issues 193 (2002); Tony Simoes Da Silva, Desire, Mateship, and 'National Type': Vance Palmer's Legend for Sanderson, 13 Australian STUdies 70, 70-81 (1999); H.G. OXLEY, Mateship IN LOCAL ORGanization: A Study of Egalitarianism, Stratification, Leadership, and Amenities Projects in a SemiINDUSTRIAL COMMUNITY OF INLAND NEW SOUTH WALES 1 (1978).

587. See ClaRK, supra note 528, at 211-12.

588. See id. at 205-10.

589. See id. at 204.

590. See id. at 205-12.

591. See generally id. at 19.

592. Dean Jaensch, Remaking the Australian Constitution, 14 CURRENT AFF. Bull. 14-15 (1981).

593. See CLARK, supra note 528, at 116-17 
functioned as an off-shore concentration camp for political dissidents and criminal misfits from Great Britain. ${ }^{594}$ The cruelty within these prison colonies in New South Wales, Tasmania, and Queensland, founded in the wake of the American Revolution, was well known and documented. ${ }^{595}$ The colonial governments brutally crushed dissension within them. ${ }^{596}$ Prisoners that survived and the governments released remained dependent upon the military for sustenance and protection in a hostile and alien environment. ${ }^{597}$ Although the Australian colonies began attracting yeoman farmers squeezed out of Great Britain by the industrial revolution from the early 1800 s, with the exception of one colony, South Australia, which was established purely as a colony for the English lower middle class, early colonization was not characterized by the ideal of a new utopia. ${ }^{598}$ It was not until after the Gold Rush in 1851, and the consolidation of personal pastoral empires, that the abundance of Australian natural resources became evident to the outside world such that people saw Australia as a place of opportunity rather than ignominious exile. ${ }^{599}$

Throughout its early history Australia remained geographically isolated from the world and heavily dependent on Great Britain for protection. $^{600}$ Great Britain shipped food and materials to enable the colonies, which lacked the expertise to adapt to the native environment, to survive. ${ }^{601}$ Great Britain also provided military protection from other imperial powers, especially the Asian hordes to the north, the fear of which continues to underlie the Australian psyche today and partly explains Australia's current harsh response to asylum seekers. ${ }^{602}$ Up until the mid-twentieth century, Great Britain was Australia's primary export market. ${ }^{603}$ At the time of federation, Australians viewed Great Britain more as a loving parent of a child ready to leave the nest, than as an oppressor unwilling to give up an opportunity for imperial exploitation. ${ }^{604}$

594. See id. at 18-35.

595. See Robert Hughes, The Fatal Shore: The EPIC of Australia's Founding chs. 915 (1987).

596. See ClARK, supra note 528, at 24-25.

597. See id. at 24-26.

598. See id. at 27-35.

599. See id. at 126-50.

600. See generally id. at 9-35.

601. Id.

602. E.g., Hamish Fitzsimmons \& John Schauble, Good Name Takes a Battering, F2 NETWORK, Aug. 30, 2001, available at http://old.smh.com.au/news/0108/30/national/national7. html.

603. ClARK, supra note 528, at 301 .

604. See generally id. at 204-12. 
Great Britain's authority was benign and the population did not require protection from it. ${ }^{605}$

Because of their dependence on the supply of food and materials from Great Britain, the Australian colonies settled around the coastal fringe, and that pattern of settlement continues today. Consequently there is a considerable distance between the coastal urban centers and the interior. Prior to the era of airplane travel, reliable road transport networks, and telecommunications, these distances played an important role in the formation of Australian character. ${ }^{606}$ Despite the highly urbanized nature of Australian society, mateship and the bush were and continue as pervasive cultural influences. ${ }^{607}$ The combination of these two influences gave rise to a celebration of rugged individualism and self-sufficiency similar to those noted in American society, however with one qualification. ${ }^{608}$ Distance and a harsh environment prevented those living in the interior from pursuing purely selfish agendas. ${ }^{609}$ Out of necessity, those living and working in the outback were dependent upon each other for support. ${ }^{610}$ The outback isolated them from the institutions of law and order, which were concentrated in the urban centers. ${ }^{611}$ Consequently the logic of co-operation rather than the individualized pursuit of personal claims characterized the way they dealt with each other. ${ }^{612}$ Moreover, those living in the interior remained highly dependent on the state for the provision of infrastructure (such as roads and communications) and for the provision of income maintenance through subsidy, import protection, and market assistance. ${ }^{613}$ Consequently, most of the political unhappiness emanating recently from this sector of Australian society is the result of the decreasing availability of such state support, which has gradually dismantled as Australia has embraced globalization and the ideology of the World Trade Organization. ${ }^{614}$

605. Id

606. BLAINEY, supra note 584 , at ch. 6.

607. S. EnCEl, Equality and Authority: A Study of Class, Status and Power in Australia Ch. 16 (1970); J.D.B. Miller, Australia 37 (1966); Russell Ward, The AUSTRALIAN LEGEND Ch. 1 (2nd ed., 1965).

608. GeORGE NADEL, AUSTRALIA's COLONIAL CULTURE 52-56 (1957).

609. Id. at 54; WARD, supra note 607, at 77-87; See N.T. Feather, Value Systems Across Cultures: Australia and China 21 INT'L J. PsYCHOLOGY 697, 712 (1986) (contending that although Australians demonstrate a concern toward self fulfillment and enjoyment, they also see friendship and altruistic and affiliative views as important).

610. R.M. CRAWFORD, AUSTRALIA $135-39$ (4th ed., 1979); ENCEL, supra note 607, at 1048; NADEL, supra note 608, at 54; WARD, supra note 607, at 96.

611. W.K. HANCOCK, AUSTRALIA 273 (1930)

612. Id. at 274-75.

613. DaVID Mosler, Australia, THE ReCreational SOCIETY 28 (2002).

614. See ClARK, supra note 528, at 39-46. 
Compared with American society, Australian society has generally been more heavily dependent on the State. ${ }^{615}$ Consequently, while the Australian population might describe politicians and bureaucrats with a disdain similar to that expressed by Americans, in reality Australians look to the State as obligated to protect and promote their personal welfare $^{616}$ Initially, this arose out of necessity because the Australian population was too small and too diffusely spread to facilitate the capital investment in infrastructure necessary to establish and sustain the standard of living characteristic of modern western economies. ${ }^{617}$ Originally, the government established and maintained road networks, rail networks, telecommunications, water supplies, power supplies and so on. ${ }^{618}$ Infrastructure was publicly rather than privately owned, although the government has divested itself of much of this role over the past ten years, as its ideology shifted from supervisor to a more laissez-faire role. ${ }^{619}$

Furthermore, until recently, the State committed to intervening in the market to ensure that the fruits of economic growth were distributed fairly; egalitarianism in Australia meant more than equality of opportunity, it also meant social justice. ${ }^{620}$ Until about ten years ago, Australia had a system of centralized wage fixation. ${ }^{621}$ The government heavily subsidized and protected the manufacturing industry through tariffs and import restrictions. ${ }^{62}$ Statutory monopolies marketed export products, and in some cases continue to market these products. ${ }^{63}$ Universal health care (although increasingly under threat due to diminished resources), remains a commitment of the present government along with social welfare for many in the community. This includes plans such as: the age pension, single parents' benefits, veterans' entitlements, unemployment benefits of unlimited duration, disabled pensions, and sickness benefits..$^{24}$

Consequently the individualism, liberty, and laissez-faire values (which Lipset argues explain the rights oriented and anti-statist attitude

615. See generally id. at 300-27.

616. See id.

617. See generally id. at 178-210.

618. See id. at 206-07.

619. A SociologY OF AUSTRALIAN SOCIETY 80 (Jake M. Najman \& John S. Western eds., $3 d$ ed. 2000).

620. KeEping It Together: State AND Civil SocietY In Australia 53-59 (Adam Farrar \& Jane Inglis eds., 1996).

621. Id.

622. See Clark, supra note 528, at 200-01.

623. See generally id. at $237-40$.

624. Clark, supra note 528, at 333. 
of American society), ${ }^{625}$ have not been replicated to the same degree in Australian society where the populace has traditionally viewed the State as a source of succor and protection. Australians did not colonize their country to escape religious oppression. ${ }^{626}$ Australia was a military outpost of Great Britain on whom most Australians were dependent and to whom most owed allegiance. ${ }^{627}$ Australia had no need to articulate rights within a constitutional context, and moreover, no tradition of judicial oversight of breaches of human rights in the criminal investigation process. ${ }^{628}$

None of the Australian colonial constitutions incorporated protection of rights. ${ }^{629}$ When Australia became a federated nation in 1901 there was an opportunity to redress this deficiency, and include rights within the new national constitution. The Constitution included a limited number of rights, such as the right to freedom of religion, ${ }^{630}$ the right to a jury trial for indictable Commonwealth offenses, ${ }^{631}$ and the prohibition against discrimination between persons from different states. ${ }^{632}$ However, the new nation rejected a proposal for equal protection under the law and a guarantee of due process. ${ }^{633}$ The view was that the inclusion of such rights in the Constitution was unnecessary and that the government and Parliament should be trusted to abide by the rule of law. ${ }^{634}$ Australian constitutional history was not characterized by the same degree of distrust of the state and its potential to exercise oppressive power that characterized the formation of the United States Constitution. ${ }^{65}$ Some text.

625. LIPSET, supra note 535, at 20-21; see also supra notes 543-545 and accompanying

626. Although that may have been the reason for later emigration by European minorities such as the Silesians who migrated to the Barossa Valley in South Australia in the mid-nineteenth century.

627. See generally CLARK, supra note 528, at 18-35. (1999).

628. See George Williams, Human Rights Under the Australian Constitution 41

629. Except Tasmania, which by section 46 of their Constitution provides for freedom of religion and conscience.

630. AUSTL. CONST. $§ 116$.

631. Id. $\S 80$. The inclusion of a right to trial by jury in section 80 was potentially an important safeguard in Australian criminal procedure. Originally the proposal put forward was a guarantee of trial by jury for "all crimes cognizable by any court." Id. However in successive drafts, the proposal was watered down so as to apply only to "[t]he trial on indictment of any offence." Id. Because the federal parliament could determine which offenses were indictable, it could effectively evade this protection by characterizing the offense as summary. Moreover as the bulk of criminal cases are heard by state courts not federal courts, the protection afforded by Section 80 has proven illusory.

632. Id. $\S 117$.

633. J.A. La NaUZe, The MaKing of THE AUSTRalian CONSTitution 230-32 (1972).

634. See generally id.

635. Id. 
even thought that the inclusion of such rights in the Constitution would reflect negatively on Australian civilization because it would imply that the populace could not trust the government. . $^{336}$

More sinisterly, the drafters of the Australian Constitution were aware of the U.S. decisions based on the Fourth Amendment that had prevented discrimination against African-Americans and ChineseAmericans. A substantial number of delegates to the Australian Constitutional Conventions wanted to ensure that Australian states were able to continue to enforce racist laws. Examples of such laws are the Western Australian legislation that prevented any Asiatic or African alien from obtaining a miner's licence, and the Victorian factory legislation that discriminated against the Chinese on the basis of alleged "sweating" practices. $^{637}$

The paucity of protections for civil and political rights in the Australian Constitution and its emphasis upon the preservation of states' interests, the need to protect free trade, and the limitation of Commonwealth power, demonstrates that the Constitution was essentially a compact between the former Australian colonies rather than a compact between the new national government and its citizens. ${ }^{638}$ The Australian Constitution actually omitted the concept of citizenship because Australians still saw themselves as British subjects. ${ }^{639}$ Australian society retained British values and structures including the racial views of its patriarchal Anglo-Saxon dominated society. ${ }^{640}$ Aborigines, for example, were ignored and considered a dying race. ${ }^{641}$

While Australia imported the structural separation of the executive, legislative, and judicial arms of the State found in the Australian Constitution from the United States, it retained the institution of responsible government inherited from Great Britain. ${ }^{642}$ The records of the Australian Constitutional Convention and further academic literature, at least up until the 1960s, indicate that the adoption of responsible government was regarded as a further panacea for the failure to adopt constitutionally based human rights. ${ }^{6+3}$

636. Id at 231 .

637. Id. at 231-32; WILLIAMS, supra note 628 , at 41 .

638. WILLIAMS, supra note 628, at 26.

639. See id.

640. HANCOCK, supra note 611 , at $\mathrm{Ch}$. III.

641. Nicholas Peterson \& Will SANDERS, Citizenship and Indigenous Australians Ch. 1 (1998).

642. E.g., The Right Honorable Sir Onen Dixon, Jesting Pilate: and Other Papers AND ADDRESSES 101 (1965).

643. E.g., Id. at 102; SiR R.G. Menzies, Central Power in the Australian COMMONWEALTH 52-54 (1967). 
Under responsible government, the Executive branch is formed by reason of its majority in Parliament. ${ }^{644}$ In theory, the Executive holds power as long as it maintains the confidence of Parliament. ${ }^{645}$ In turn, Parliament is directly responsible to the people through the election process. ${ }^{646}$ The accountability of the Executive in Parliament extends to the acts of ministers, acts undertaken by ministerial departments, and acts undertaken by government instrumentalities. ${ }^{647}$ Responsible government is further bolstered by the availability of judicial review from an independent court. ${ }^{648}$

To provide an effective check against abuse of power by the Executive, the theory of responsible government depends upon the efficacy of parliamentary overview. ${ }^{649}$ However, the monopolization of political influence into the hands of two major parties (Liberal/National vs. Labor) together with the development of strong party discipline have resulted in domination of Parliament by the Executive rather than strong parliamentary accountability. ${ }^{650}$ The business of Parliament has simply become too complex and voluminous to provide an effective check against individual instances of abuses of civil rights. ${ }^{651}$ Moreover, as a result of the Executive's domination over Parliament, the response to systemic problems remains the Executive's prerogative. ${ }^{652}$

The increasing domination of the Executive and the failure of Parliament to act as an effective check on abuses of power have provided a rationale for increasingly active judicial review. ${ }^{653}$ That rationale has been further strengthened as a result of the attenuated role of the state as a provider of infrastructure, facilitator of commercial exchange, and an agent of social justice. ${ }^{654}$ As the State has become more laissez-faire and as the Australian economy has become more liberalized so that society is less egalitarian, Australian courts have begun to develop a form of rights

644. Brian Galligan, Parliamentary Responsible Government and the Protection of Rights, 4 PuB. L. REV. 100, 111 (1993); Marian Simms, Models of Political Accountability and Concepts of Australian Government, 58 AUSTL. J. PUB. ADMIN. 34, 34-37 (1990).

645. See Galligan, supra note 644, at 103-04.

646. See id.

647. See id.

648. See id.

649. See generally id.

650. Id. at 111.

651. See id. at 102 .

652. See id.

653. Gerald Brennan, The Purpose and Scope of Judicial Review, in JUDICIAL REVIEW OF ADMINISTRATIVE ACTION IN THE 1980s: PROBLEMS AND PROSPECTS 18-19 (Michael Taggart ed., 1986).

654. See gencrally id. 
jurisprudence. ${ }^{65}$ Arguably, when the people regarded the State as a benefactor, the need for rights based jurisprudence was not pressing. ${ }^{6.56}$ The advent of globalization and the shrinking mandate of the State have ironically led to a concomitant enthusiasm on the part of the courts to protect rights more vigorously than in the past. ${ }^{657}$ International covenants, like the International Covenant on Civil and Political Rights (ICCPR), have aided this development, ${ }^{658}$ as well as the constitutional separation of judicial power. ${ }^{659}$

Nonetheless, as outlined in Part II of this Article, the development of a rights based jurisprudence remains embryonic and constitutionally unprotected. Furthermore, the development remains limited by the attitude of Australian courts toward matters of criminal procedure, and their reluctance to elevate individual rights above considerations of law and order. Australian criminal procedure is couched in terms of protecting the integrity of the criminal process, rather than protecting the individual from unjustified interference by the State. Courts view criminal procedure rules as a means to protect the integrity and reliability of evidence needed to ensure they attain proper convictions. Hence, illegally or improperly obtained evidence or evidence that operates unfairly against an accused is not subject to mandatory exclusion. Rather the courts will examine a number of balancing factors outlined in Part IV of this Article and will only intervene when convinced that the failure to observe rights threatens confidence in the court and its procedures. This official centered view of the court's role regarding interference with civil liberty is also reflected in the common law of entrapment.

As noted above, the cultural context for the Australian courts' attitude has been the perception of a benign state in contrast to the distrustful perception of government present in the United States. Americans might criticize Australian courts for merely paying lip service to rights. From an Australian standpoint, however, the domination of

655. See generally id.

656. See Brian Head, The Role of State Intervention, in AUSTRALIAN STUDIES: A SURVEY (James Walter ed., 1989).

657. Hon. Ronald Sackville, Continuity and Judicial Creativity-Some Observations, 20 U.N.S.W.L.J. 145, 152 (1997).

658. ICCPR, supra note 338; Dietrich v. The Queen (1992) 177 C.L.R. 292, 321 (per Brennan, J.); Minister of State for Immigration \& Ethnic Affairs v. Teoh (1995) 183 C.L.R. 273; Jago v. District Court New South Wales (1988) 12 N.S.W.L.R. 558.

659. In re Tracey Ex parte Ryan (1989) 166 C.L.R. 518, 580 (per Deane, J.). Reliance on international covenants and judicial decisions from other nations is rarely found in American court holdings. For two notable exceptions, see Lawrence v. Texas, 123 S. Ct. 2472 (2003) (invalidating anti-sodomy statutes); Miranda v. Arizona, 384 U.S. 486 (1966) (providing the famous four warnings needed for interrogations). 
rights based jurisprudence is both unnecessary, given the adherence to the rule of law by the State, and undesirable because it undermines the community's confidence in the courts to ensure and enforce law and order.

\section{CONCLUSION}

The divergence between criminal procedure rules of the United States and Australia can thus be summed up as:

1. a distinct rights-based jurisprudence practiced in the United States, which seeks to protect individuals from undue interference by the State;

2. an "official centred" jurisprudence practiced in Australia, which looks to the preservation of the integrity of the courts and the criminal process they administer.

However, it would be wrong to assume that the divergent approaches necessarily reflect that U.S. courts will always uphold individual rights over communitarian interests, or that Australian courts will always uphold communitarian interests over individual rights.

While the U.S. courts have developed mandatory exclusion rules regarding unlawful search and seizure and improperly obtained confessional evidence, there is a good deal of jurisprudence which demonstrates that communitarian interests play an important role in limiting the scope of those rules. ${ }^{660}$ Communitarian interests, for example, lie behind decisions such as California v. Ciraolo and New Jersey v. T.L.O., and show that it is only unreasonable interference with individual privacy that will give rise to mandatory exclusion. ${ }^{661}$ Similarly, Australian cases such as Coleman v. Zanker, Pavic v. The Queen, and $R$. v. Ridgeway demonstrate that the improper restriction of individual rights will not be tolerated where it results in convictions obtained at too high a price, consequently undermining the court's role in upholding the rule of law. ${ }^{62}$

Nonetheless, it does appear more likely that evidence, that has been illegally obtained or will operate unfairly against a defendant, will be more readily excluded in the United States compared with Australia. Once due process has been breached in respect to a confession or real (1985).

660. See California v. Ciraolo, 476 U.S. 207 (1986); New Jersey v. TLO, 469 U.S. 325

661. See Ciraolo, 476 U.S. at 207; T.L.O., 469 U.S. at 325.

662. Coleman v. Zanker (1991) 58 S.A. St. R. 7; Pavic v. The Queen (1998) 192 C.L.R. 159; R. v. Ridgeway (1995) 184 C.L.R. 19. 
evidence obtained without lawful authority, courts mandate exclusion in the United States. In Australia, the courts are reluctant to exercise their discretion in favor of exclusion, especially where the evidence is cogent and the police have acted in good faith, albeit somewhat overzealously.

The entrapment jurisprudence of each jurisdiction is particularly illustrative. The Australian view is to permit entrapment unless the government involvement comprises part of the offense with which it has charged the defendant. If it does, the evidence obtained as a result of the entrapment can be (but does not have to be) excluded at the court's discretion. By contrast, the United States approach does not focus upon the legality of investigating officials, but looks instead to the effect that the investigating officials' behavior has upon the criminality of the defendant. In the United States, entrapment is a complete defense where behavior of investigating authorities has improperly incited or induced a crime. Entrapment thus operates as a per se prohibition on the behavior of investigating officials. In Australia, unless the investigating officials participate in the crime in a more direct and substantial way, the courts will not intervene. Blanket legislative immunities passed in some Australian states, and at the federal level, have limited the scope of the court's discretion even further, so as to preclude them from excluding evidence obtained by entrapment.

The official centered approach of Australian courts as compared with U.S. courts is not only echoed in the rules of admissibility. Rules regarding media scrutiny of the courts and the examination of jurors and their deliberations also show that Australian courts are far more protective of their procedures than their U.S. counterparts, who rely upon greater transparency and accountability as a means of engendering public confidence. Australian courts express a stronger fear of media manipulation and will go to greater lengths to prohibit interference with their processes through the laws of contempt and the use of suppression orders. On the other hand, U.S. courts rely more upon management of media influence through the change of venue procedure, the voir dire process of juror selection, and sequestration, if required.

The continued secrecy of juror deliberations is a particularly puzzling aspect of Australian justice. It is designed to keep jurors anonymous and to protect them from fear of repercussion or corruption. However, continued secrecy also alienates the jury from the community and makes jurors unaccountable for their decision-making. Despite this difference, Australians, like their American counterparts, overwhelmmingly express the view that jury decisions are fair. 
The divergence between the United States and Australia is culturally based and neither approach could be transposed to the other's jurisdiction. In Australia, dependence on government, and the culture of social justice, has reduced the belief in the need for protection from government tyranny. However, that picture is changing as Australia has adapted rapidly to globalization and has dismantled state enterprise.

Australian judges seem to think that if they gave individual rights greater protection, community confidence in courts would diminish. The current success of politicians using "get tough" law and order campaigns as electoral bait would appear to confirm that view. ${ }^{63}$ In the absence of constitutional foundation, Australian courts do not see a need to mandate the introduction of a rights-based jurisprudence. From their perspective, an approach which balances community expectations for security against community expectations that police will behave appropriately, will produce the best outcome.

The American approach is very different. U.S. courts provide a forum where individuals can assert their rights. The State, which potentially can repress and harm individuals, is restrained from encroaching upon those rights. The approach of U.S. courts is embedded in American culture and history, a history of seeking refuge from religious persecution, breaking away from an oppressive imperial power, the promise of a land of individual opportunity, and the celebration of self-sustained individualism. ${ }^{664}$

The criminal trials in Chicago and Melbourne, mentioned earlier in this Article, appear at first glance to be quite similar. Upon reflection, however, one sees fundamental differences in the two criminal justice systems, differences which reflect very basic views about the relationship of the two governments to their citizens.

663. Jake Skeers, Australia: State Election Descends into Law-and-Order Bidding War, WORLD SOCIALIST WEB SITE, Mar. 14, 2003, available at http://www.wsws.org/articles/2003/ mar2003/nsw-m14.shtml (last visited Oct. 7, 2003).

664. The point is best illustrated in the celebrated and widely quoted dissenting opinion of Justice Brandeis in the Olmstead case, noted earlier decrying government violation of the law. See Olmstead v. United States, 277 U.S. 438, 485 (1928) (Brandeis, J., dissenting); see discussion supra text accompanying note 562 . 